DANIEL RODELLI

\title{
Paleoceanographic variations through the study of rock magnetic properties: biogenic magnetite as a new paleoenvironmental indicator
}

Thesis presented to the Instituto Oceanográfico, Universidade de São Paulo as part of the requirements for the attainment of the title of Doctor of Science, program of post-graduation in Oceanography, area of Oceanographic Geology

Advisor: Prof. Dr. Luigi Jovane

São Paulo, 2018 


\section{Instituto Oceangráfico}

Paleoceanographic variations through the study of rock magnetic properties: biogenic magnetite as a new paleoenvironmental indicator

Daniel Rodelli

\section{VERSÃO CORRIGIDA}

Tese apresentada ao Instituto Oceanográfico da Universidade de São Paulo, como parte dos requisitos para obtenção do Título de Doutor em Ciências, área de Oceanografia Geológica

Julgada em

Prof (a). Dr (a).

Prof (a). Dr (a).

Prof (a). Dr (a).

Prof (a). Dr (a).

Prof (a). Dr (a). conceito

conceito

conceito

conceito

conceito 
Science can't see what

it doesn't have the language to describe

John Hunton

(Let's find the language) 


\section{Aknowledgements}

To my Family, my mother, my father and my sister.

To Carolina, my little star, my happiness

To my parents-in-law and my brothers-in-law, that made me feel once more at home far from home.

To my advisor, Prof. Luigi Jovane, for making this PhD possible, for all the help and support, for the moral lessons, and for the endless stream of samples from all over the world that he gave me over these years.

To all the many people that during this years worked at the CORE laboratory. We shared a lot of fun and a lot of stressful moments, but we made through them with a laugh at the end.

To all the people of the Instituto Oceanográfico: professors, technician, students, which had a part in this project.

To the countless collaborators from all over the world that helped shape this projectand the scientific papers.

Financial support for the execution this project was provided by FAPESP (grant number 12/21213-2), supplementary financial support also provided by CAPES Ciências do Mar project. 


\section{Summary}

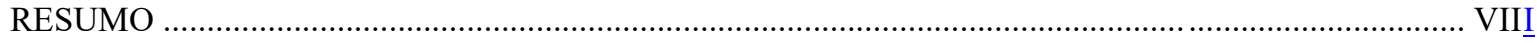

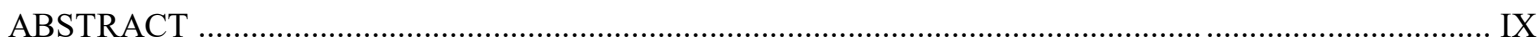

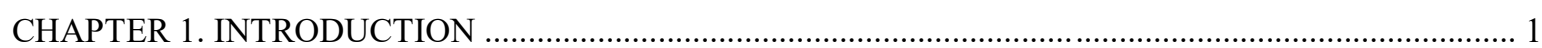

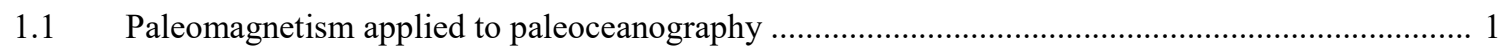

1.1.1 The importance of biogenic magnetite ………………................................................................ 1

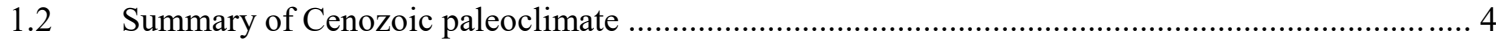

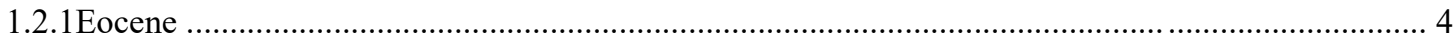

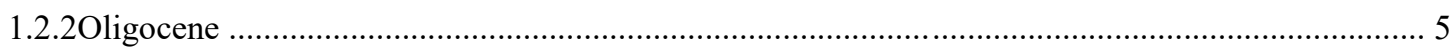

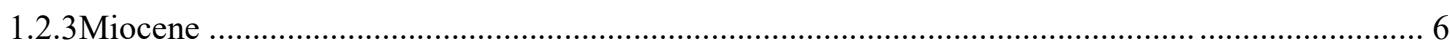

1.3 Objectives

1.4 General Outline

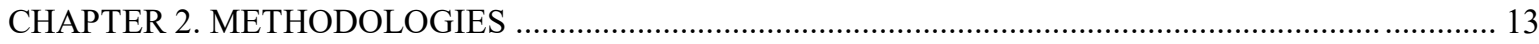

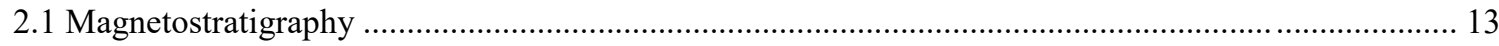

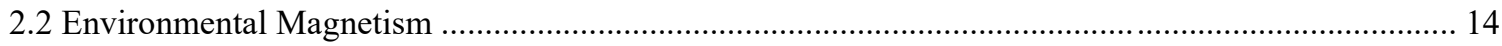

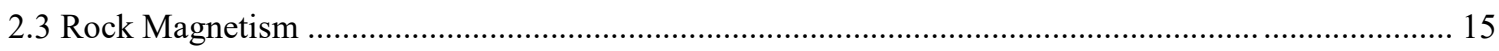

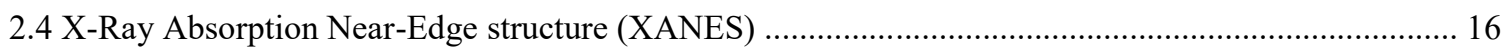

Chapter 3. Biogenic magnetite as a possible indicator of sedimentary chemical stratification: a comprehensive

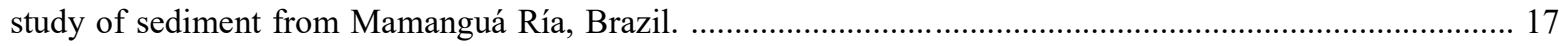

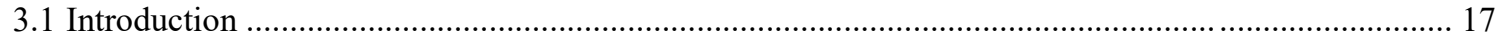

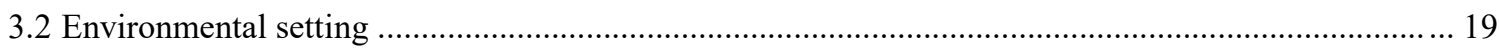

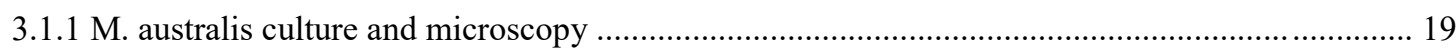

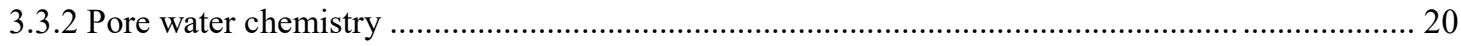

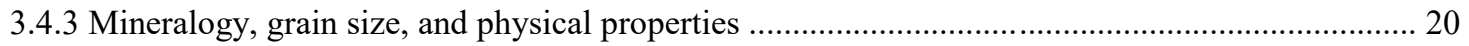

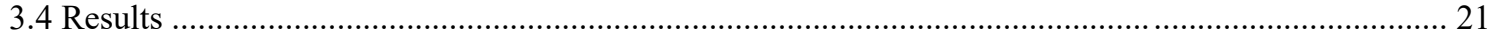

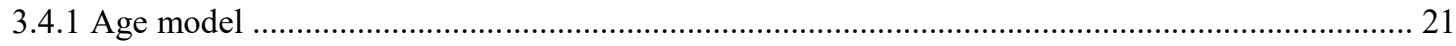

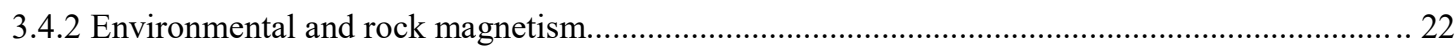

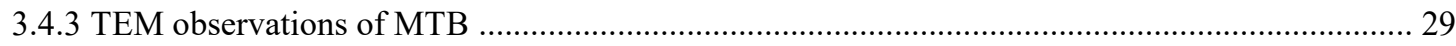

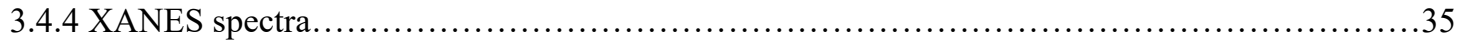

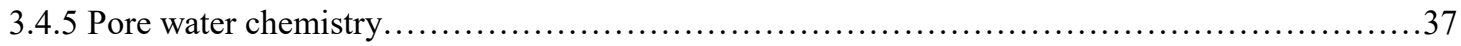

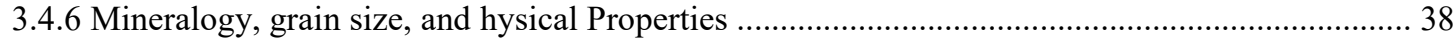

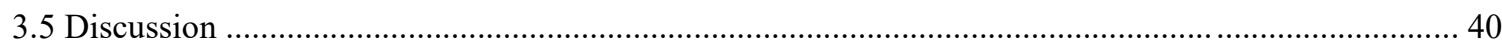

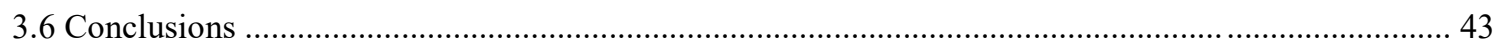


Chapter 4. Effects of the closure of the Neo-Tethys on currents from the Indian Ocean to the Atlantic Ocean: an example from a newly descripted section from central Turkey (Elazı̆̆ Province)

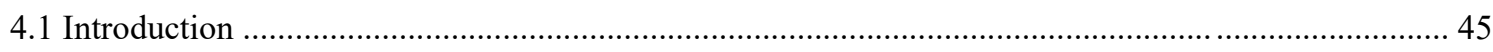

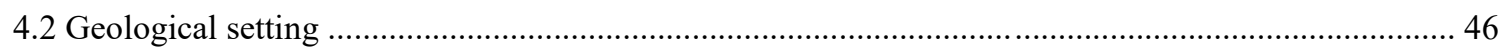

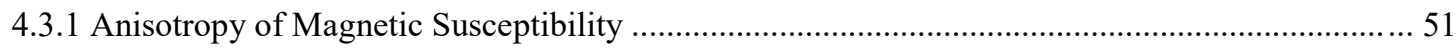

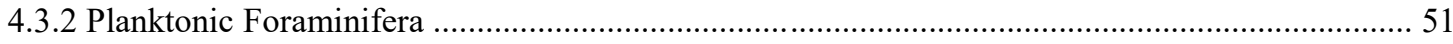

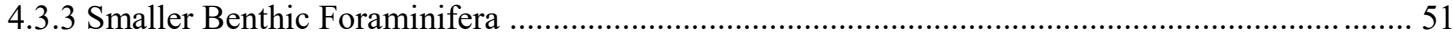

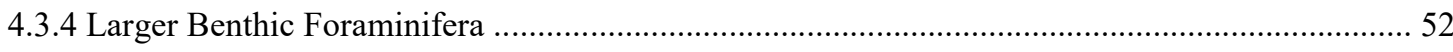

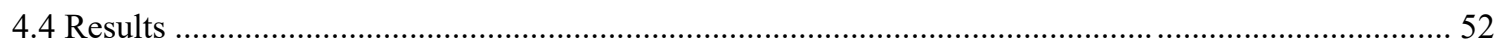

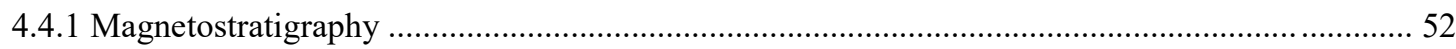

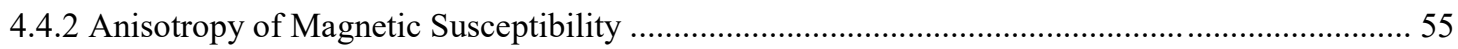

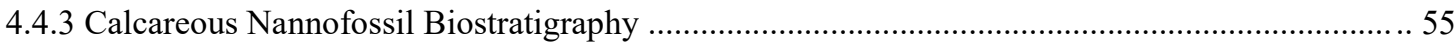

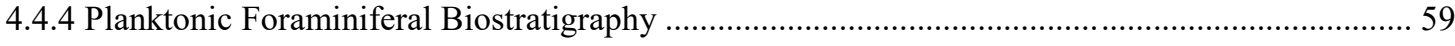

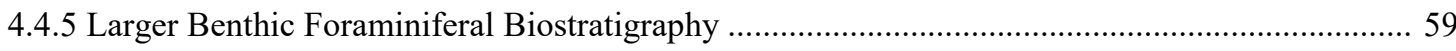

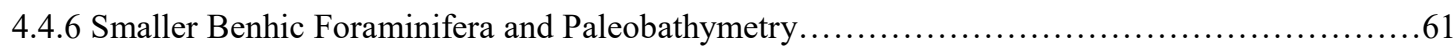

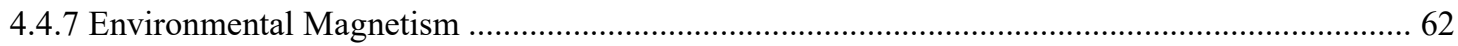

4.4.8 Correlation to the Geomagnetic Polarity Time Scale .....................................................65

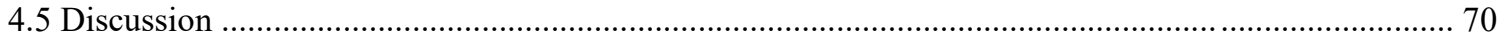

4.5.3 AMS and tectonic implications of the Baskil Section ................................................... 70

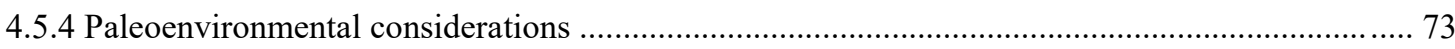

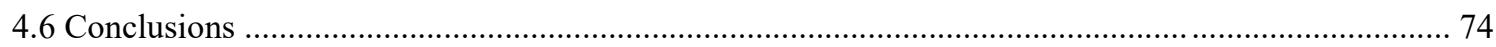

Chapter 5. Antarctica ice sheet evolution during the Upper Eocene - Middle Miocene through environmental and rock magnetic studies: example from a sedimentary core from the Ross Sea (DSDP Leg28, Site 274) ... 76

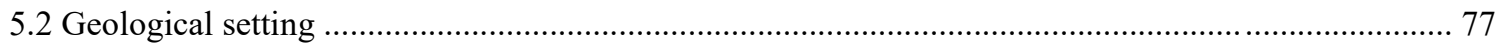

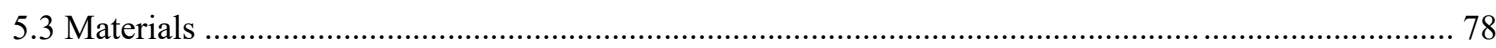

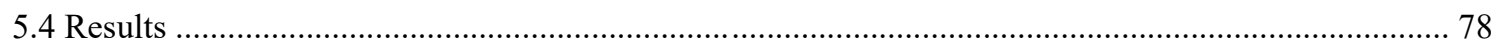

5.4.1 Magnetostratigraphy 78

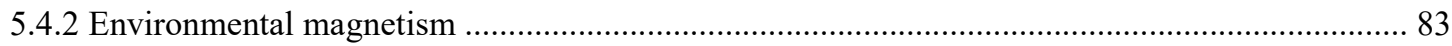

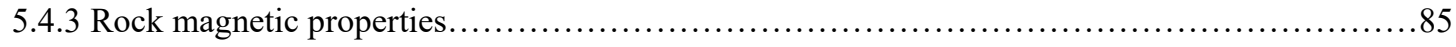

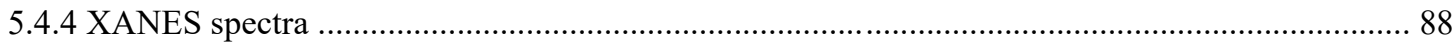

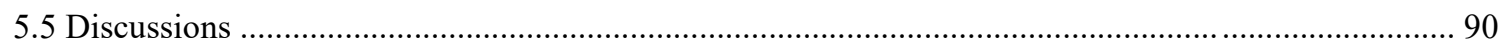

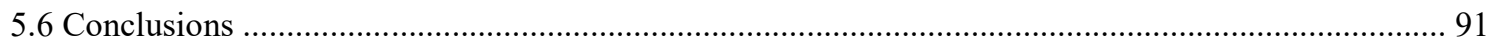

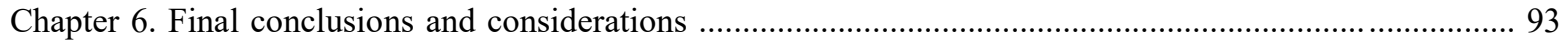

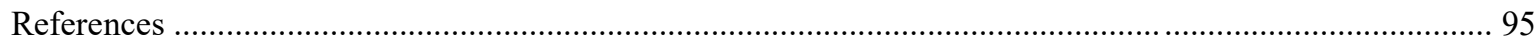




\section{Index of figures}

Figure 1 Schematic representation of the pathways of Fe bearing minerals............................................... 2

Figure 2 Magnetotactic bacteria morphotypes observed in sediments of Mamanguá Ría (RJ, Brazil).. ............ 3

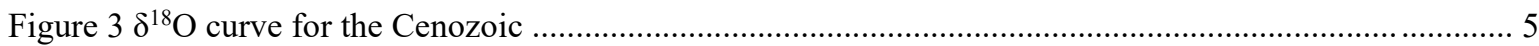

Figure $4 \delta^{18} \mathrm{O}$ data from planktonic and benthic foraminifera from Deep Sea Drilling Project (DSDP) Site

608. (n)

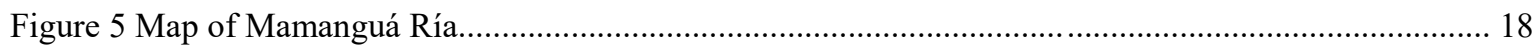

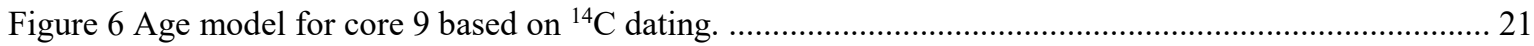

Figure 7 (previous page) Down-core magnetic parameter variations for core 9. (a) Lithological log, (b-h)

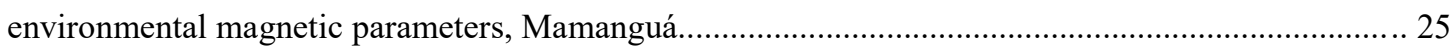

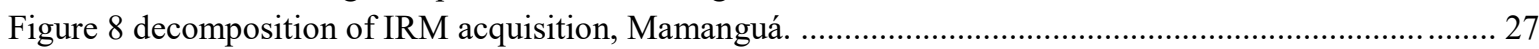

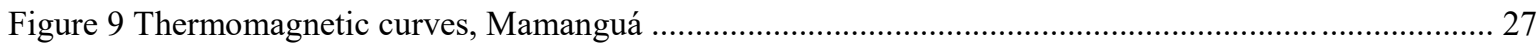

Figure 10 Rock magnetic properties and FORC PCA, Mamanguá. …….................................................... 29

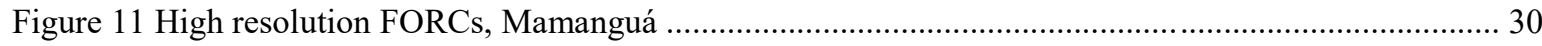

Figure 12 (A) TEM images of magnetotactic bacteria, Mamanguá ............................................................ 31

Figure 13 Low-resolution FORCs of core 9, mamanguá ………............................................................. 32

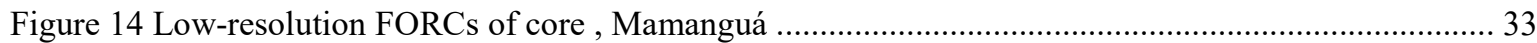

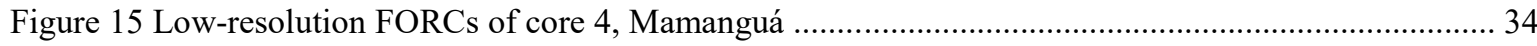

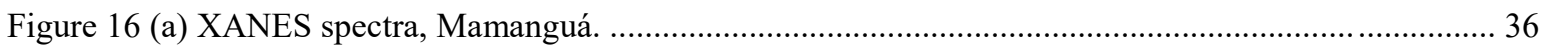

Figure 17 DO, ORP and dissolved Fe in the pore waters, Mamanguá ……................................................... 37

Figure 18 lithological and physical properties of Core 9, Mamanguá ........................................................ 39

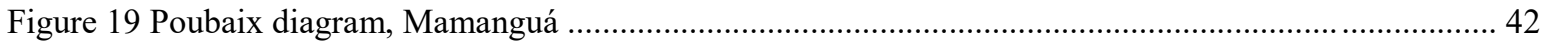

Figure 20 Schematic geological map of the Elazı̆ğ-Baskil area. ..................................................................... 48

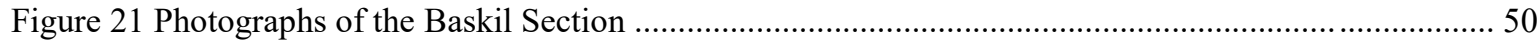

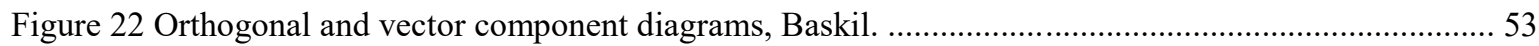

Figure 23(A) Stratigraphic log, magnetozones, and biozones, Baskil. …....................................................... 54

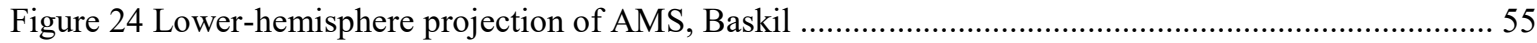

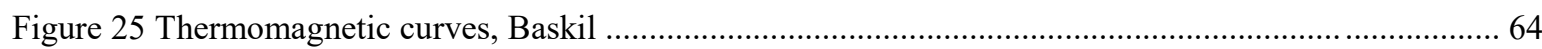

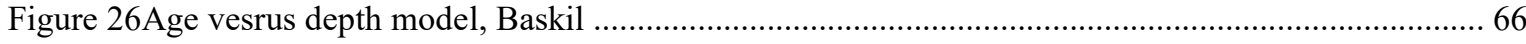

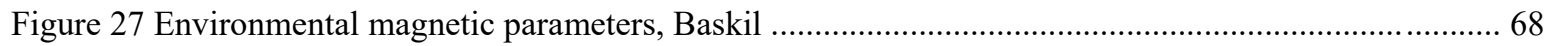

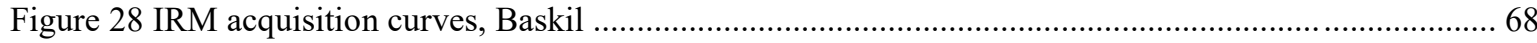

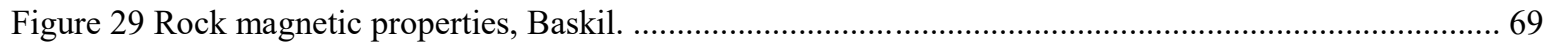

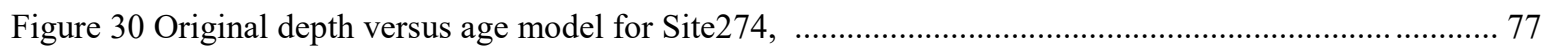

Figure 31 Position of DSDP Hole 274 NE of Cape Adare. ……........................................................... 78

Figure 32 Examples of orthogonal demagnetization plots, Site274 …................................................... 80

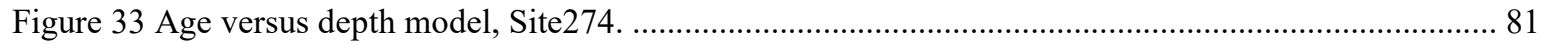

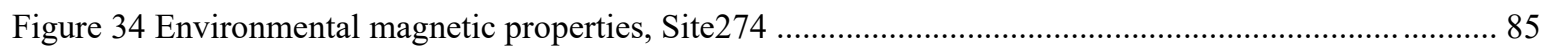

Figure 35 Examples of rock magnetic properties, Site274. ..................................................................... 86

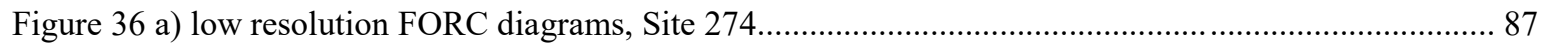


Figure 37 rock magnetic properties of the Miocene part of Site274.

\section{Index of tables}

Table 1 Latitude, longitude, and water depth of the analyzed cores. 20 Table

2 Numerical values of the main features of XANES spectra and IRM components, Mamanguá 36 Table 3

Magnetozone boundaries and sedimentation rate, Baskil Section. 68

Table 4 Bioevent and chon boundaries, with their numerical ages, Baskil Section. 72

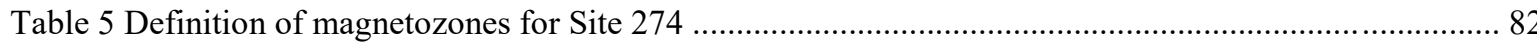

Table 6 Numerical values of the main features of XANES spectra, Hole 274 89

\section{Abbreviations used in the text}

AF Alternating Field

AMS Anisotropy of Magnetic Susceptibility

ARM Anhysteretic Remanent Magnetization

BIRM Backfield Isothermal Remanent Magnetization

CCD Calcite Compensation Depth

ChRM Characteristic Remanent Magnetization

D.O. Dissolved Oxygen

EAIS East Antarctic Ice Sheet

EM End Member

FORC First Order Reversal Curve $\mathbf{H}_{\mathbf{c}}$

Magnetic Coercivity

HB "Hard" Biogenic magnetite

IRM Isothermal Remanent Magnetization

Ms Saturation Magnetization $\mathbf{M r}_{\mathbf{r}}$

Magnetic Remanence

Mbsf Meters Below Sea Floor MCT Miocene

Cooling Trend

MD Multidomain

MECO Middle Eocene Climatic Optimum 
MMCO Middle Miocene Climatic

Optimum msl Meters stratigraphic level

MTB Magnetotactic Bacteria

Orp Oxi-Reduction Potential

PCA Principal Component Analysis

PSD pseudosingle Domain

SB "Soft" Biogenic magnetite

SD Single Domain

SMT Sulphate-Methane Transition

SIRM Saturation Isothermal Remanent Magnetization

SP Superparamagnetic

SMT Sulphate-methane Transition 


\section{RESUMO}

RODELLI, D. Variações paleoceanograficas através do estudo das propriedades magnéticas: a magnetita biogênica como novo indicador paleoambiental. 2018, Tese (Doutorado). Instituto Oceanografico, Universidade de São Paulo, São Paulo.

A historia climática da Terra é caracterizada por variações climáticas de curto e longo prazo, com variações de condições, as vezes extremas. Dados de isótopos de oxigênio mostram claramente que durante o Cenozoico (desde $65 \mathrm{Ma}$ até o presente) o nosso planeta passou de uma fase quente caracterizada por marcado efeito estufa (durante o Paleoceno) para um período progressivamente mais frio em direção ao presente. Ambos esses estados são caracterizados pela alternância de eventos transientes quentes e frios de relativa curta duração, sendo que destes a maioria ainda não é plenamente compreendida. Um dos principais problemas das reconstruções paleoceangráficas é que quanto mais antigo o evento mais difícil encontrar sequências sedimentares cujo registro de proxies paleoambientais seja preservado e confiável. Este trabalho visa explicitar a possibilidade de desenvolver um novo indicador paleoambiental, baseado em propriedades magnéticas de cristais de magnetita biosintetizados por bactérias magnetotáticas. Tais cristais biogênicos são notavelmente sensíveis a pequenas variações de oxigênio dissolvido na coluna de água e na agua intersticial entre os poros dos sedimentos marinhos, e essa sensibilidade pode ser explorada para reconstruir variações climáticas no registro sedimentar do passado. Informações qualitativas estão disponíveis na literatura cientifica mas, até agora, não existem estudos que quantifiquem essa relação. Esta primeira tentativa de quantificar a preservação de magnetita biogênica em função do estado de oxigenação de águas se baseia em testemunhos coletados na costa do estado do Rio de Janeiro (Saco do Mamanguá, Paraty), onde foi possível coletar dados magnéticos relativos aos cristais de magnetita biogênica concomitantemente a medidas diretas de química da água intersticial. Os resultados desse primeiro estudo foram aplicados para reconstruções de variações climáticas e oceanográficas em duas seções que registram importantes mudanças climáticas durante $o$ Paleogeno. No primeiro caso, um afloramento localizado na Turquia central de idade Eocenica e representativo de um período de rápido aquecimento (Ótimo Climático do Eoceno Médio, Middle Eocene climatic Optimum, MECO). No segundo caso, um testemunho coletado no Mar de Ross (Antártica) que abrange o período entre o Eoceno superior e o Mioceno médio, durante o qual houve a formação da primeira cobertura de gelo permanente no continente antártico. 


\section{ABSTRACT}

RODELLI, D. Paleoceanographic variations through the study of rock magnetic properties: biogenic magnetite as a new paleoenvironmental indicator. 2018, Doctorate thesis. Oceanographic Institute, University of São Paulo, São Paulo.

The climatic history of the planet Earth is characterized by long- and short-term climatic variations. Oxygen isotopic data clearly shows how during the Cenozoic (from $65 \mathrm{Ma}$ to the present) our planet shifted over time, from greenhouse to icehouse climate states up to the present. Along this progressive cooling, the record is dotted by rapid warming and cooling transient events, from which the causes are not yet fully understood. One problem with paleoceanographic reconstructions is that the older the event, the harder it is to find a sedimentary record in which the paleoclimatic proxies are preserved enough to be used with confidence.

This work has the goal of illustrating the possibility to develop a new paleoenvironmental indicator based on the magnetic properties of magnetite crystals synthetized by magnetotactic bacteria. The sensibility of such crystals to small changes in dissolved oxygen content in the pore water and water column is well known, and can be exploited to reconstruct such changes from the sedimentary record. Qualitative information regarding this topic are defined in scientific literature, but, so far, no quantitative study has been performed. This is the first attempt to quantify the preservation of biogenic magnetite as a function of oxygenation state of waters, and is based on recent sediment extracted from cores collected in the coastal region of Rio de Janeiro (Saco do Mamanguá, Paraty). From these, where it was possible to obtain magnetic data relative to magnetite crystals together as well with as direct measurements of pore water chemistry.

The results of this first attempt were used to analyze climatic and oceanographic conditions in two other sites, representative of key past environmental events during the Paleocene. The first case study was performed in a newly descripted sedimentary outcrop in central Turkey, of middle Eocene age, representative of a period of rapid warming (Middle Eocene Climatic Optimum, MECO). The second case study was done using material from a marine sediment core collected in the Ross Sea (Antarctica) that covers from the late Eocene to the Middle Miocene, a period that saw the onset of the modern, permanent ice sheet cover in the Antarctic continent 


\section{CHAPTER 1. INTRODUCTION}

\subsection{Paleomagnetism applied to paleoceanography}

Environmental magnetism is based on the principle that it is possible to correlate the magnetic properties of mineral assemblages to the environmental processes that control them (e.g. Thompson et al., 1980; Thompson and Oldfield, 1986; Oldfield, 1991; Verosub and Roberts, 1995). As environmental and rock magnetism are increasingly used in paleoenvironmental studies (e.g. Verosub and Roberts, 1995; Evans and Heller, 2003, Jovane et al., 2007, Suganuma et al., 2009, Liu et al., 2012), we expect to recognize patterns in the magnetic characteristics of the sediment that can be linked to known paleoclimatic events (Zachos et al., 2001, Lear et al., 2004, Coxall and Wilson, 2005).

Magnetic minerals are a class of iron-bearing minerals that occur in nature as oxides (e.g., magnetite $\left[\mathrm{Fe}_{3} \mathrm{O}_{4}\right]$, maghemite $\left[\gamma-\mathrm{Fe}_{2} \mathrm{O}_{3}\right]$, hematite $\left[\alpha-\mathrm{Fe}_{2} \mathrm{O}_{3}\right]$, and hydroxides like goethite and lepidocrocite) and sulphides (e.g., greigite, pyrrhotite). These minerals are extremely sensitive to oxidative and reductive conditions during transportation, deposition, and diagenesis (Liu et al., 2012, Roberts, 2015). The dissolution and precipitation of Fe minerals is chemically controlled by $\mathrm{pH}$, dissolved oxygen (DO), oxi-reduction potential (ORP), and biological activity (Pérez-Guzmán et al., 2010, Roberts, 2015). $\mathrm{Fe}^{2+}$ will rapidly oxidize to $\mathrm{Fe}^{+3}$ in oxic environments (e.g. Stumm and Morgan, 1996), while $\mathrm{Fe}^{3+}$ will be reduced in reductive conditions (Figure 1). Therefore, iron-bearing minerals are stable only in a limited range of ORP-pH conditions (Garrels and Christ, 1965; Pourbaix, 1974; Brookins, 1988); and this property can be exploited to reconstruct past environmental conditions.

\subsubsection{The importance of biogenic magnetite}

One of the effects of changes in paleoceanographic and paleoclimatic conditions is a variation in primary productivity. Primary productivity is controlled by the distribution and availability of nutrients in the seawater, where Fe, which is used in processes such as nitrate reduction and nitrogen fixation (Jickells at al., 2005; Sigman and Hain, 2012), plays an important role. A major source of iron to the oceans is dust delivered by the winds from 


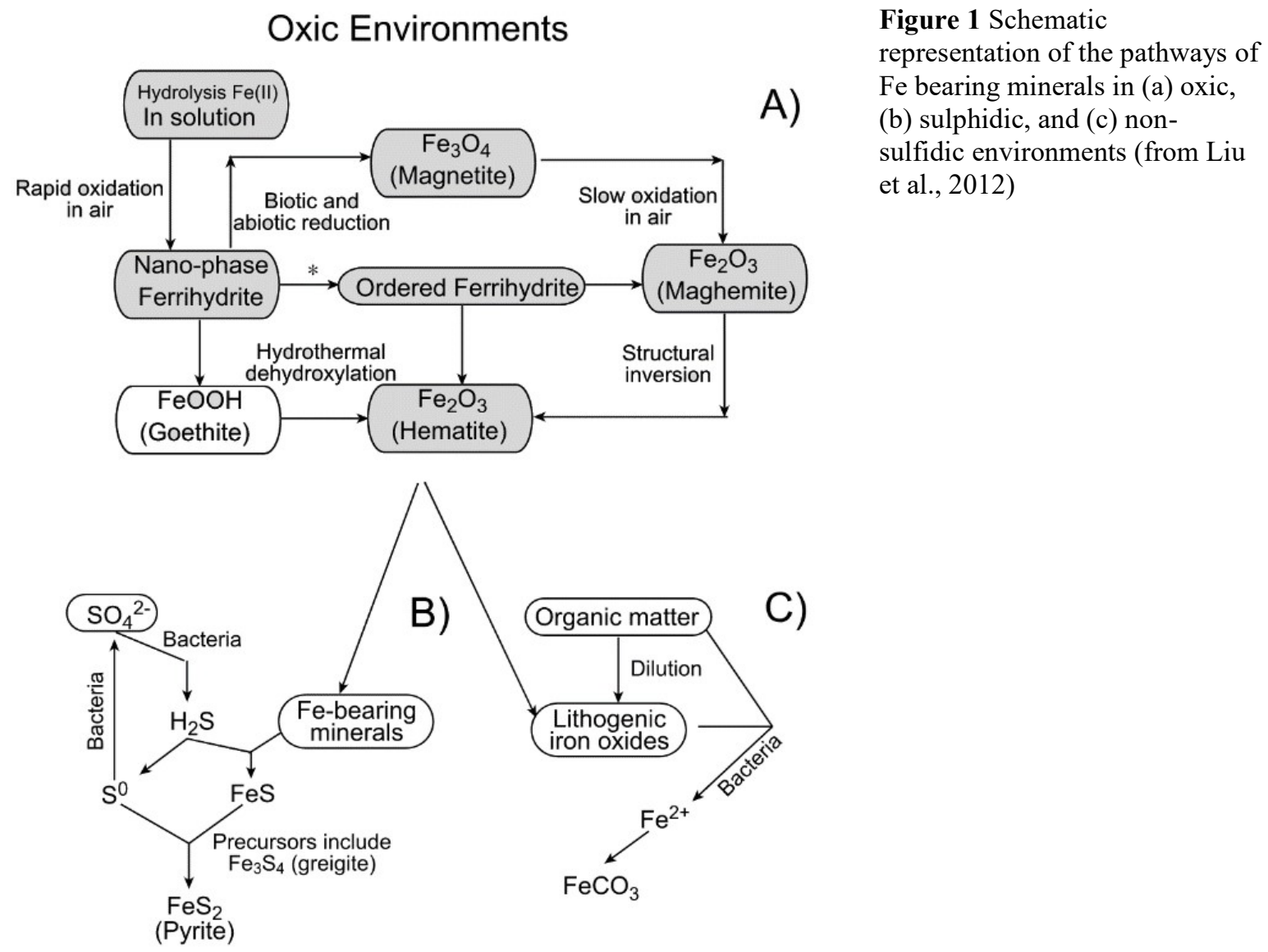

Sulfidic Environments Non-Sulfidic Environments

deserts (Martin and Fitzwater 1988). In the last few years, the study of relative abundance of biogenic magnetite, produced by magnetotactic bacteria, has become an increasingly important parameter to assess variations in paleoproductivity (e.g. Jovane et al., 2012, Savian et al., 2014, 2016).

Magnetotactic bacteria (MTB) are a polyphyletic group of prokaryotes that biomineralize membrane-bound magnetic minerals (Bazylinski, 1993; Bazylinski and Frankel, 2004). These sub-micrometer magnetite $\left(\mathrm{Fe}_{3} \mathrm{O}_{4}\right)$ or greigite $\left(\mathrm{Fe}_{3} \mathrm{~S}_{4}\right)$ crystals are aligned in chains within a phospholipid bilayer that forms an organelle called a magnetosome (Figure 2). The magnetic chain enables the bacterium to move parallel to magnetic field lines in a function known as magnetotaxis. The dimensions of crystals are optimized for ideal stable single-domain (SD) magnetic behavior. Their spatial organization means that the magnetic flux of individual particles is linked along the chain to produce a strong overall magnetic anisotropy so that a magnetosome chain behaves like a single long non-interacting SD particle (Dunin-Borkowski 
et al., 1998). This non-interacting SD fingerprint is used extensively to identify magnetically the inorganic fossilized remains of MTB (magnetofossils) in sediments (Kruiver and Passier, 2001; Egli, 2004a; Egli et al., 2010). Once MTB die, magnetofossils can remain preserved for millions of years (Chang and Kirschvink, 1989).

The biogenic magnetite was recognized, in the recent decades, as one of the main mineral carriers of paleomagnetic signal. Its importance stems from the fact that biogenic magnetite is a perfect recorder of the magnetic directions of the geomagnetic field at the time of deposition. This fact is related to the perfect size, shape, and chemical composition to preserve the original magnetic directions over long time scales $\left(>10^{7}\right.$ years $)$

Presence of biogenic magnetite as magnetofossils has been linked to global warming and events of high primary productivity (Schumann et al, 2008; Roberts et al, 2011, 2012; Chang et al, 2013; Larrasoaña et al, 2012). The study of these bacteria and of their magnetofossils in ocean sediments (Housen and Moskowitz, 2006; Tarduno et al, 1998) could be used as an indicator for climatic conditions because of the very restrict conditions where they survive. Magnetofossils provide important information on past environmental conditions, and they can be the main source of paleomagnetic signals in marine and terrestrial environments. MTB occur commonly in water-logged soils and lakes; however, marine forms are paleoclimatically important because their abundance can be related directly to climate variations, ecosystem changes, nutrient production, and organic matter concentration during diagenesis (Roberts et al., 2011, 2013; Jovane et al., 2012; Yamazaki and Ikehara, 2012; Savian et al., 2014; 2016).

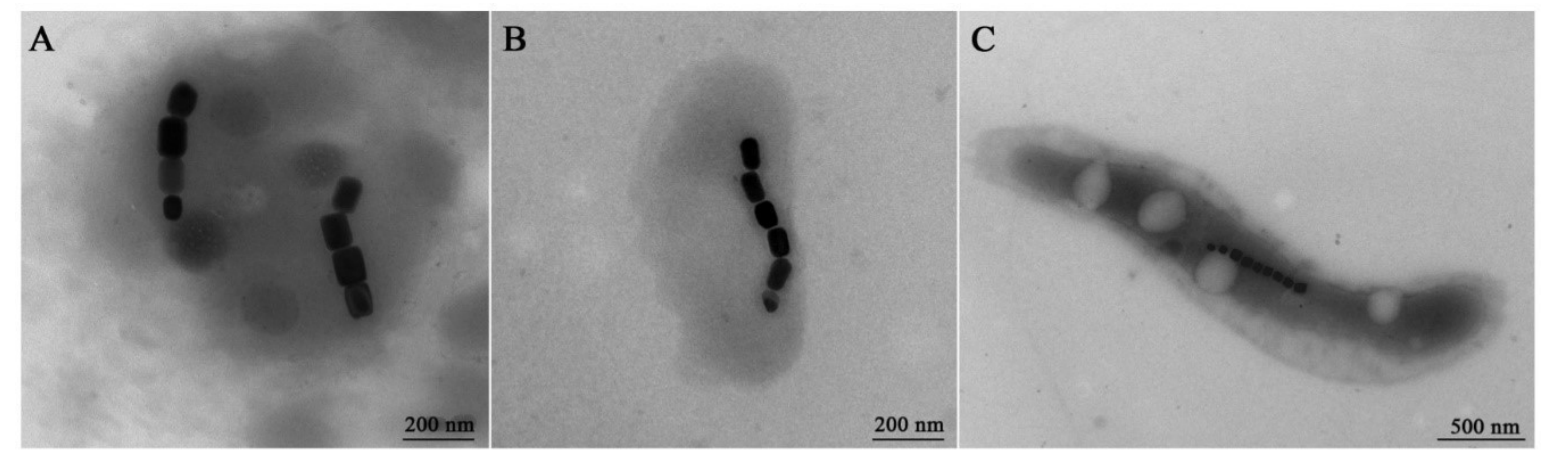

Figure 2 Magnetotactic bacteria morphotypes observed in sediments of Mamanguá Ría (RJ, Brazil). Transmission electron microscope images of a coccus with two magnetosome chains (A), a vibrio (B) and a spirillum (C) with one magnetosome chain. 


\subsection{Summary of Cenozoic paleoclimate}

The Cenozoic is a period of the Earth's history that includes various important paleoclimatic events. During this time, the planet shifted from a greenhouse state, stablished since the Mesozoic, to an icehouse climate. Global warming and cooling climatic conditions appear at different time scales, each in response of several processes such as tectonic evolution $\left(\sim 10^{6}\right.$ years) and orbital forcing $\left(10^{4}-10^{5}\right.$ years) (e.g. Zachos et al., 2001; 2008) (Figure 3). On shorter timescales $\left(10^{3}\right.$ years $)$ rapid, transient, extreme climatic events, most of them called hyperthermals, dotted the climatic record.

\subsubsection{Eocene}

The Eocene represents an important period in the paleoclimatic history of the Earth. In this epoch, the warming trend that began during the late Paleocene transitioned into a cooling phase from the Early Eocene Climatic Optimum (EECO, 50-52 Ma) as revealed by deep-sea oxygen isotope records, to the end of the Eocene Epoch (e.g. Miller et al., 1991; Zachos et al., 2001, 2008). After the EECO, the climate system shifted from greenhouse conditions to icehouse conditions. Superimposed to this long-term cooling trend, short-term fluctuations occurred, with cooling (e.g. Tripati et al., 2005) and warming events (e.g. Bohaty and Zachos, 2003; Jovane et al., 2010; Bohaty et al., 2009).

In this view, the most relevant event is the Middle Eocene Climatic Optimum (MECO, Bohaty and Zachos., 2003; Jovane et al., 2010; Bohaty et al., 2009; Edgar et al., 2010; Savian et al., 2014). The MECO event is interpreted as a period of global warming (Bohaty et al., 2009), and is marked by negative excursions of benthic foraminiferal $\delta^{13} \mathrm{C}(\sim 1.0 \%)$ and $\delta^{18} \mathrm{O}$. This event, which encompasses several different phases (Savian et al., 2014), began at $40.7 \mathrm{Ma}$ and ended at $\sim 39.6 \mathrm{Ma}$ (Jovane et al., 2007). Reconstruction of $\mathrm{pCO}_{2}$ suggests a warming of sea-

temperatures of about $5^{\circ} \mathrm{C}$ (Bijl et al., 2010). The trends of $\delta^{13} \mathrm{C}$ and $\delta^{18} \mathrm{O}$ of the MECO event differ significantly from those of the previous hyperthermals (Sluijs et al., 2013). The duration of this event indicate that the $\mathrm{CO}_{2}$ rise originated from a long-term imbalance between input and burial of carbon in the system. Discrepancies exist between the field data and theory, such as the predicted increase in weathering due to higher temperatures, leading to a higher alkalinization and carbon saturation state, resulting in a deepening of lysocline and CCD, while 
field data suggest a shallowing of the CCD, with a reduction of carbonate sediments (Sluijs et al., 2013).

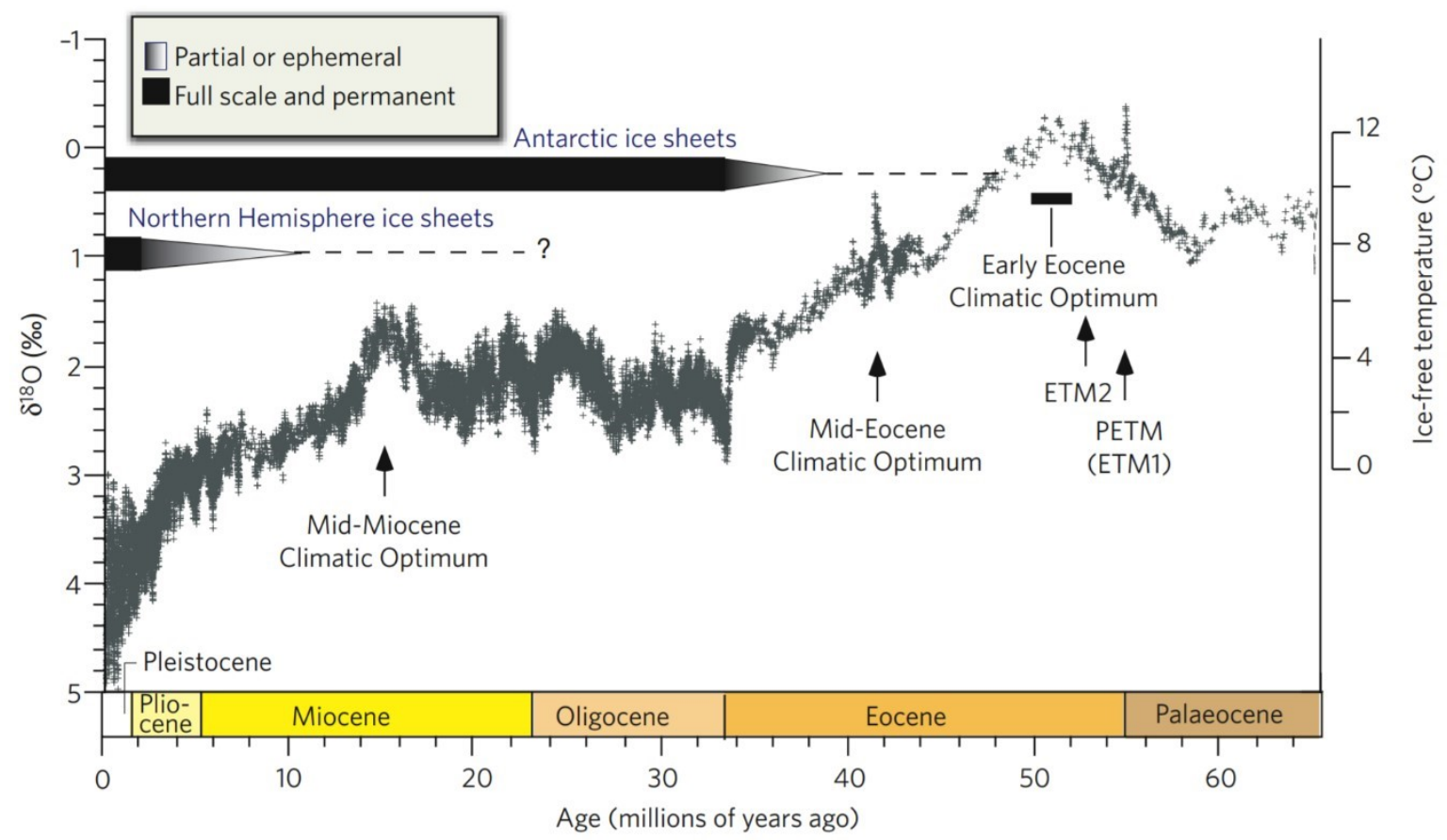

Figure $3 \delta^{18} O$ curve for the Cenozoic, with major paleoclimatic events marked. From Zachos et al. (2008)

\subsubsection{Oligocene}

Earth climate saw a major shift from greenhouse to icehouse conditions since the early Eocene, that culminated with the permanent onset of continental scale Antarctic ice sheet at ca. $34 \mathrm{Ma}$ (event Oi-1a), marked in the geological record by a 4\%o positive shift in benthic foraminifera $\delta^{18} \mathrm{O}$ (Miller et al., 1991; Zachos et al., 2001), representing a significant cooling in sea surface and deep temperatures (Zachos et al., 2001; Villa et al., 2008; Boahty et al., 2012). The Eocene Oligocene boundary is marked by the development of large, perennial, ice sheets in Antarctica (Shackelton and Kennet, 1976; Zachos et al., 1996; Coxall et al., 2005; Lear et al., 2008). The opening of oceanic gateways around the Antarctic continent that would form the Southern Ocean may have played an important role in the onset and stabilization of the Antarctic ice sheet (Exon et al., 2004; Barker and Knorr., 2007). This impressive climate shift was associated with reduction of atmospheric $\mathrm{CO}_{2}$ (Pearson et al., 2009), deepening of the CCD and increased ocean alkalinity (Coxall et al., 2005). During the early Oligocene Antarctica expanded, reaching from modern-time size (Liu et al., 2009) up to 25\% bigger (Wilson et al., 2013). This 
expansion is connected to an estimate relative sea level fall of approximately $70 \mathrm{~m}$ (Miller et al., 2005).

During the Oligocene, global temperatures and the expanse of Antarctic ice sheets fluctuated on short ( $<500 \mathrm{Kyr})$ and long (2-3 Myr) timescales (Lear et al., 2008), terminating with a major increase in size of the latter at the Oligocene-Miocene transition (23 Myr, event Mi-1). The causes of such fluctuations are still not fully understood, but is accepted influenced by orbital parameter variations (Ladant et al., 2014). Orbital phasing between glacial cycles and marine $\delta^{13} \mathrm{C}$ records indicates that carbon cycle feedbacks contributed to $\mathrm{CO}_{2}$ variations and amplification of short- and long-period eccentricity-paced glacial-interglacial cycles in the Early Oligocene (Galeotti et al., 2016).

\subsubsection{Miocene}

The Miocene is characterized by the alternation between extreme climactic optima and longterm climatic coolings (Zachos et al., 2001).

The Early Miocene is characterized by major long-term changes in deep-water circulation, sea level and climate changes. The late Early Miocene shows a strong shoaling of the CCD ("carbonate famine") followed by a distinct fall in the early Middle Miocene. This deepening of the CCD in the Pacific Ocean was terminated by shoaling at $10.5 \mathrm{Myr}$ ago, in a rapid “carbonate crash" event (Lyle et al., 1995). In addition, during the early Miocene (Burdigalian) the gateway between the Indian Ocean and the Mediterranean became restricted (e.g., Reuter et al., 2009) and was closed in the early Middle Miocene (Langhian; e.g., Karami et al, 2011). The closure of the Tethyan Seaway had important consequences since it possibly affected the meridional heat transfer and global thermohaline circulation (Bryden and Kinder, 1991) and has been suggested to play an important role in the middle Miocene global cooling (e.g., Woodruff and Savin, 1989; Flower and Kennett, 1993). Also, narrowing of the Tethys seaway in the early Miocene, concomitantly with widening of the Drake Passage, reversed the flow in the Panama Seaway (von der Heydt and Dijkstra, 2006). The middle Miocene represents an important stage in the Cenozoic history because of the extremely warm conditions, followed by a rapid cooling between 14.2 and 13.8 Ma (Lewis et al., 2007). At the end of the Miocene, the Miocene Cooling Trend (MCT) represented a definitive increase of cooler conditions in the East Antarctic Ice Sheet (EAIS) and is characterized by sea level changes and variations in the 
bottom circulation (Shevenell et al., 2004). The long-term cooling trend happened stepwise, generating the so-called Mi-Events (Miller et al., 1991) that correspond with positive oxygen isotope shifts. Besides the oxygen isotope excursions, carbon isotopes exhibit a series of positive excursions, culminating in the so-called Monterey Event or Monterey Excursion (e.g., Vincent and Berger, 1985) between 16.9 and 13.5 Ma. These positive excursions exhibit a cyclic nature related to eccentricity variations (e.g., Holbourn et al., 2007). The Monterey Event is considered to be of global occurrence but the Atlantic record is nearly missing so far. The Middle Miocene Climatic Optimum (MMCO) was a global warming event at $\sim 15 \mathrm{Ma}$ (14.5-17 Ma), when global annual mean surface temperature reached $18.4^{\circ} \mathrm{C}\left(\sim 6^{\circ} \mathrm{C}\right.$ higher than today) (Shackleton and Kennett, 1975; Savin et al., 1975; Herold et al., 2009), sea-level was 25 to 40 meters higher than at present, and concentration of atmospheric $\mathrm{CO}_{2}$ was approximately 460-580 ppmv (You et al., 2009). These conditions are similar to those predicted for the next century, when temperature values can potentially increase by $3^{\circ} \mathrm{C}$ (Adams et al., 1990). Warny et al. (2009) recognized terrestrial palynomorphs in AND-2A typical of a $10^{\circ} \mathrm{C}$ environment between 15.5 and $15.7 \mathrm{Ma}$. There is an open debate in relation to the bias between higher temperatures and lower values of $\mathrm{CO}_{2}$, which seem decoupled along this event (Pagani et al., 1999; Pearson and Palmer, 2000; Kurschner et al., 2008; Herold et al., 2009). Marine and terrestrial temperatures were warmer than today and higher than at any time after the Eocene/Oligocene boundary (33.7 Ma) (Zachos et al., 2008), and although relatively warm temperatures are reasonably well documented in low and middle latitudes, they are unknown for high latitudes. 


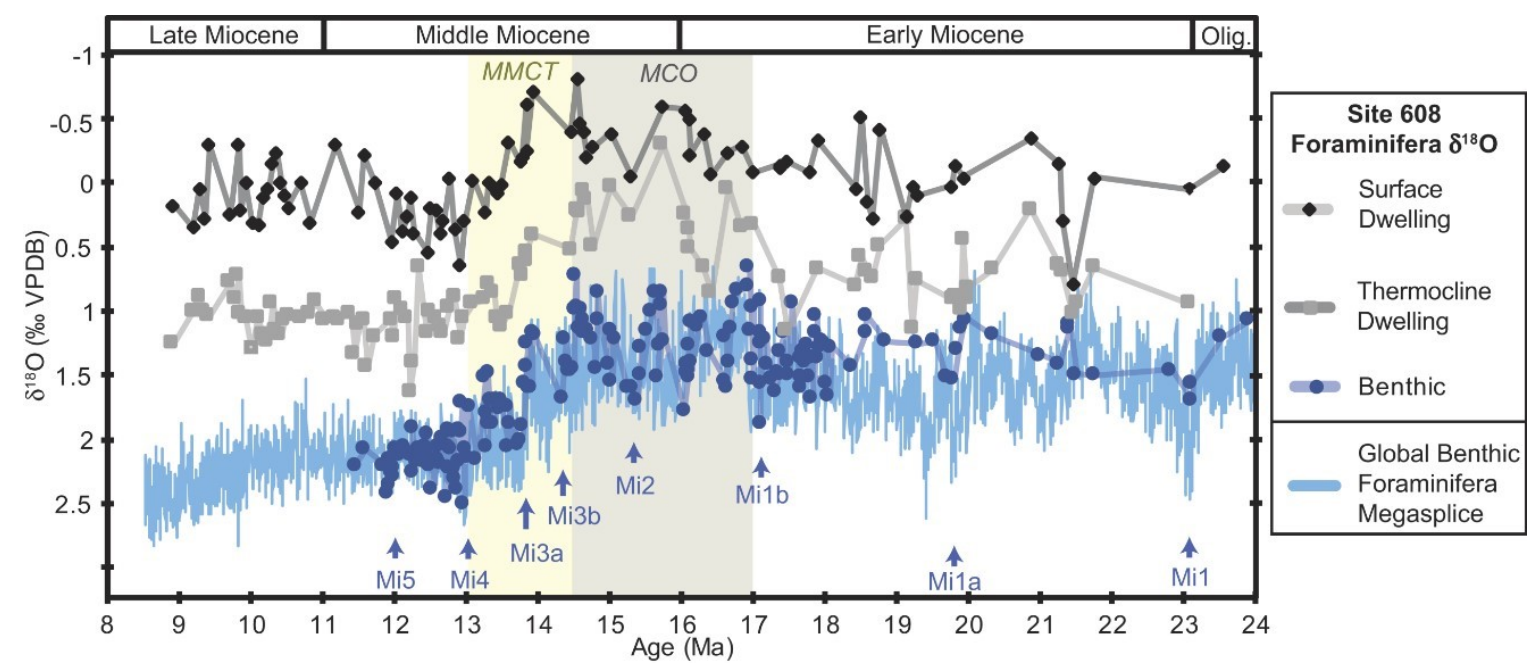

Figure $4 \delta^{18} \mathrm{O}$ data from planktonic and benthic foraminifera from Deep Sea Drilling Project (DSDP) Site 608 (after Pagani et al., 1999; Miller et al., 1991; Diester-Haass et al., 2009), plotted with a global benthic foraminifera splice (De Vleeschouwer et al., 2017) (time scale after Gradstein et al., 2012). Blue arrows indicate Miocene oxygen isotope events (Mi) (Miller et al., 1991; Miller and Mountain, 1996). Abbreviations: MMCT-Middle Miocene Climatic Transition; MCO_Miocene Climatic Optimum; VPDB-Vienna Peedee belemnite. From Super et al., 2018. 


\subsection{Objectives}

This work will address three main topics related to the application of paleomagnetic techniques to paleoceanography and paleoclimatology.

The concept that biogenic magnetite is highly sensitive to environmental conditions during both deposition and diagenesis is being discussed since the discovery of MTB, but until now, no conclusive quantitative studies have been performed to determine the effects of diagenesis on biogenic magnetite. Secondarily to this study, biogenic Magnetite represent one of the main carriers of paleomagnetic signal, and its preservation and stability over long time scales is of paramount importance for the preservation of the original magnetic directions. Chemical alteration could affect the stability of the magnetic record. For this reason, it is fundamental to quantify how biogenic magnetite responds to varying environmental conditions.

- The first object of this work is to assess if the relationship between MTB and environmental conditions can be measured with rock magnetic techniques, and whether this relationship can be expanded into a proxy for paleo-concentration of oxygen in the sediments.

Based on the hypothesis that the closing of the gateway between the Arabian and Eurasian plates, through coupling of sea-level changes, could represent the threshold or one of the triggers that caused the palaeoceanographic variations in the Neo-Tethys and in global ocean circulation patterns during the end of the Eocene (Jovane et al., 2009), the main objects of the study are to test:

- If the variability in magnetic properties are linked to changes of influx of deep iron-rich currents from the Indian Ocean thought the Neo-Tethys into the Atlantic Ocean

- if environmental magnetic parameters can prove that this modifying circulation at low latitudes may have caused deep palaeoceanographic changes in the Southern Ocean and consequently the freezing of Antarctica. 
The study of the paleomagnetic data that have been collected cover two main topics:

- Establish a chronostratigraphic framework for the time interval between middle Eocene/early Oligocene (from Lutetian through early Rupelian) which was used to integrate the other climatic components of the proposed research. This was accomplished through the integration of new and existing magneto- bio-, cyclo-, and stratigraphic data. The ultimate goal was to obtain a high-resolution age model that provided mean and specific sedimentary rates throughout the sections.

- Acquiring and analyzing magnetic records for the middle Eocene/Miocene with improved temporal resolution.

\subsection{General Outline}

\section{Chapter 3. Can biogenic magnetite be used as an oceanographic proxy?}

Living magnetotactic bacteria (MTB) synthesize chemically pure magnetite and greigite crystals in the presence of low oxygen concentrations in the water column or uppermost sediment. The magnetic characteristics of biogenic magnetite have been thoughtfully studied in the recent past, and its environmental significance is increasingly more recognized.

In this chapter, I report the findings relative to the characteristics of biogenic magnetite synthetized by living magnetotactic bacteria present in the sediment collected from the Mamanguá ría (Paraty, RJ, Brazil). These results are the first to directly quantify the boundary conditions (lithology, mineralogy, pore water chemistry) that control the growth and preservation of biogenic magnetite in sediments. The results are accompanied by iron chemistry data obtained through high energy X-ray absorption spectroscopy of both local MTB and cultivated specimens, used as an internal standard.

The conclusions of this particular study were applied to case studies relative to ancient sedimentary sequences, in order to better characterize the relationship between magnetic minerals and paleoenvironments.

The study of X-Ray absorption spectra and rock magnetic properties of discrete samples led to the publication of the following paper: 
Rodelli, D., Jovane, L., Roberts, A. P., Cypriano, J., Abreu, F., \& Lins, U. (2018). Fingerprints of partial oxidation of biogenic magnetite from cultivated and natural marine magnetotactic bacteria using synchrotron radiation. Environmental microbiology reports. 10(3), 337-343.

My contribution in this research was coordination of the paper, the measurements of magnetic properties and XANES spectra, and interpretation of data.

Contributions from the co-authors:

L. Jovane: interpretation of the data

A.P. Roberts (ANU): interpretation of the data

A.P Cypriano (UFRJ): cultivation of magnetotactic bacteria, TEM imaging, interpretation of data

F. Abreu (UFRJ): cultivation of magnetotactic bacteria, TEM imaging, interpretation of data

U. Lins (UFRJ): cultivation of magnetotactic bacteria, TEM imaging, interpretation of data

\section{Chapter 4. Case study 1: Effects of the closure of the Neo-Tethys on currents from the Indian Ocean to the Atlantic Ocean: an example from a newly descripted section from central Turkey (Elazı̆g Province)}

In Chapter 4, I present a high-resolution integrated magnetobiostratigraphy of a new Middle Eocene sedimentary section from the Elazı̆g Province (eastern Turkey). The continuous, undisturbed, and undeformed sedimentary record, together with preserved geomagnetic signal and fossil assemblages, allowed the establishment of a detailed age model, which spans from the upper part of Chron C19n.1r to the base of Chron C17n.1n (42.4 to $37.8 \mathrm{Ma}$ ). Field observations, paleontological, and paleomagnetic data showed that the section had not been affected by the widespread tectonic deformation that characterizes the region. We suggest that the magneto- and biostratigraphically calibrated Baskil section represents a new, shallowtodeep marine sequence that enables outstanding paleoceanographic and paleogeographic studies for the Middle Eocene.

The integrated magnetobiostratigraphic study of this new section resulted in the publication of the following paper:

Rodelli, D., Jovane, L., Özcan, E., Giorgioni, M., Coccioni, R., Frontalini, F.,Rego, E.R., Brogi, A., Catanzariti, R., Rostami, M. A. (2018). High-resolution integrated 
magnetobiostratigraphy of a new middle Eocene section from the Neotethys (Elazığ Basin, eastern Turkey). GSA Bulletin, 130(1-2), 193-207.

My contribution for this paper was field sampling, paleomagnetic measurements, interpretation of data, and coordination of the paper

Contributions from the co-authors:

L. Jovane: field work, preliminary paleomagnetic measurements, interpretation of data

E. Özcan: field work, large benthic foraminifera biostratigraphy, interpretation of data

M. Giorgioni: field workd, interpretation of data

Fabrizio Frontalini: biostratigraphy, discussion and interpretation of data

Eric Rego Siciliano: fieldwork and discussion of data

Andrea Brogi: discussion of tectonic issues.

Rita Catanzariti: biostratigraphy, discussion and interpretation of data

György Less: biostratigraphy, discussion of biostratigraphic data

Masoud Asgharian Rostami: biostratigraphy, interpretation of data

Chapter 5. Case study 2: Antarctica ice sheet during the Late Eocene - Middle Miocene through environmental and rock magnetic studies

In Chapter 5, I present a revision and improvement of the age model for a Late Eocene - Middle Miocene core from the Ross Sea (DSDP Site 274). The age model is used to calibrate in time the environmental and rock magnetic properties of the core. The Ross Sea represents a perfect spot to study the influence of past climatic changes on the development and evolution of the Antarctic ice sheet and its effects on the sedimentation, and on biogenic magnetite, that resulted to be extremely sensible to variations in nutrients supply and oxidation state of the water, especially during the Late Eocene to Middle Miocene period, where the Antarctic ice sheet became a permanent feature of the Continent, and its fluctuation if terms of volume and extension into the Ocean played a major role in controlling the sedimentation in the Ross Sea.

\section{CHAPTER 2. METHODOLOGIES}

In this chapter are resumed the paleomagnetic techniques employed in this work, that are common to all case studies presented in this thesis. Other methodologies relative to specific case studies are described separately in each relative chapter. 


\subsection{Magnetostratigraphy}

The first step in the study of a sedimentary record is a confiable age versus depth model in order to date any specific event. The age model was constructed based on magnetostratigraphy, integrated with biostratigraphic data.

Oriented samples were used for paleomagnetic studies. Samples were either cut in laboratory from hand-size samples collected from outcrops or directly obtained from split cores, in both cases the obtained samples were of roughly $8 \mathrm{~cm}^{3}$ in volume, with size of $2 \times 2 \times 2 \mathrm{~cm}$. Magnetic susceptibility $(\chi)$ was measured on every sample using a KF1 model or MFK model Kappabridge (Agico) prior to any other analysis.

Natural Remanent Magnetization (NRM) was measured with a 2G Enterprises Long Core Squid Magnetometer, located in a shielded room in order to avoid noise from the Earth magnetic field. To remove any secondary magnetic component, which could mask the original magnetic signal, an Alternate Field (AF) demagnetization technique was employed, with stepwise demagnetizations of $2.5,5,10,15,20,30,40,50,60,70,80,90$, and $100 \mathrm{mT}$.

I used vector component diagrams to display the stepwise demagnetization data (Zjiderveld, 1967; Dunlop, 1979) with the PuffinPlot software by Lurcock and Wilson (2012). After recognizing the Characteristic Remanent Magnetization (ChRM), which was considered the primary component, the ChRM directions were calculated using the principal component analysis developed by Kirschvink (1980).

The data were screened and a common standard was selected in order to exclude samples of low quality: samples have been excluded if the Mean planar Deviation Angle (MAD) was greater than $12^{\circ}$ (in the figures these samples are marked as "poor quality"), samples showing a ChRM with an inclination in the opposite direction relative to those of the nearest samples were marked as "outliers"; samples with an inclination shallower than $\pm 10^{\circ}$ were excluded too, and marked as "low Inc".

\subsection{Environmental Magnetism}

Magnetic properties were studied on all the samples in order to obtain information on the variation of characteristics of the magnetic minerals present throughout the section. Magnetic 
susceptibility $(\chi)$ was measured on every sample using a KF1 model or MFK model Kappabridge (Agico) prior to any other analysis.

Artificial magnetic fields of known characteristics were used in order to study the response of the samples in different conditions, the techniques involving such artificial fields are:

-The anhysteretic remanent magnetization (ARM), measured imposing a low intensity, constant, magnetic field of $0.005 \mathrm{~T}$ while performing $\mathrm{AF}$ demagnetization in three steps $(100 \mathrm{mT}, 300 \mathrm{mT}, 900 \mathrm{mT})$;

-The study of isothermal remanent magnetization (IRM), performed imposing first a pulsed magnetic field of $0.9 \mathrm{~T}$ in one direction, then, after measuring the acquired magnetization, new fields of lower intensity, at $100 \mathrm{mT}$ and $300 \mathrm{mT}$ in the opposite direction.

These analyses can give information about the relative abundance of magnetic minerals in the samples.

From these measurements various indirect parameters were calculated, describing the magnetic mineralogy:

- S-Ratios (as S-Ratio300: IRM@300/IRM@-900, andS-Ratio100 IRM@100/IRM@900) which give information on the relative abundance between low and high coercivity minerals;

- hard coercivity remanent magnetizations (HIRMs, defined as HIRM300 (IRM@300+IRM@-900)/2 and HIRM100 (IRM@100+IRM@-900)/2), which give information about the relative concentration of high coercivity minerals.

- Magnetic grain size (calculated as the ratio between ARM and IRM), which gives information about the relative grain size of the magnetic particles.

The environmental and magnetic mineralogy interpretations of the parameters follow the definitions of Thompson and Oldfield (1986), Oldfield (1991), and Walden et al. (1999). (See Liu et al., 2012, for a more complete definition of the parameters).

\subsection{Rock Magnetism}

Selected samples were used to study in more detail the magnetic mineralogy, in order to measure or calculate with precision the abundance and characteristics of the magnetic mineral assemblage of the sample. Also, the definition of the magnetic minerals that carry primary 
$(\mathrm{ChRM})$ and secondary magnetic components is useful to better understand the magnetization processes that result in the definition of the magnetic zonations.

The samples chosen for this analyses were powdered and about $1 \mathrm{~g}$ of material put in a gelatin capsule to perform the following analyses:

- $\quad$ Acquisition of IRM, with samples put in progressively higher magnetic field until the IRM reached saturation (SIRM), in a maximum field of $1.8 \mathrm{~T}$, with 100 acquisition steps. IRM curves were separated into discrete coercivity components (e.g. Robertson and France, 1994) with cumulative log-Gaussian (CLG) functions using the software of Kruiver et al. (2001). The software lists different characteristics of the magnetic minerals associated with each component, such as saturation IRM, coercivity spectrum, and relative percentage.

- Hysteresis loops: samples are put in artificial field progressively increasing to a maximum value of $1.8 \mathrm{~T}$ and then decreasing until reaching a magnetic field with opposite direction and equal intensity (1.8T). From the hysteresis loops, values of magnetic remanence $\left(\mathrm{M}_{\mathrm{r}}\right)$, magnetic coercivity $\left(\mathrm{H}_{\mathrm{c}}\right)$, and magnetic saturation $\left(\mathrm{M}_{\mathrm{s}}\right)$ were calculated.

- Thermomagnetic curves: the samples are incrementally heated up to $700^{\circ} \mathrm{C}$ and their susceptibility measured at regular intervals. This analysis is used to measure the Curie (or Neel) temperature of the magnetic minerals, which is unique for each kind of magnetic phase. Also, mineralogical transitions (e.g. maghemite to magnetite or hematite) can be studied.

- $\quad$ First Order Reversal Curve (FORC): these are a class of partial hysteresis curves plotted as a two-dimensional distribution function (Roberts et al., 2000), where the horizontal dimension represents the coercivity distribution and the vertical dimension the magnetic interaction between the single magnetic particles. The diagrams were produced using the software Forcinel 3.0, developed by Harrison and Feinberg (2008). The input parameters are the following: $\mathrm{H}_{\mathrm{c} 1}=0 \mathrm{mT}, \mathrm{H}_{\mathrm{c} 2}=110 \mathrm{mT} ; \mathrm{H}_{\mathrm{u} 1}=-15 \mathrm{mT}, \mathrm{H}_{\mathrm{u} 2}=+15 \mathrm{mT}, 297$ cycles (Egli, 2004c), with stacks of at least 5 measurements per sample in order to reduce the noise to signal ratio. Low resolution FORC measurement (100 cycles instead of 297) were performed on selected samples in order to perform a principal component analysis, to separate the contributions of the different end members to the final FORCs, giving information about the relative and absolute contribution of each member to the total magnetic signal. The samples have been selected based on the interpretation of the environmental and rock magnetic analyses, focusing on part of the sections where marked changes in magnetic composition and concentration have been recognized. PCA analysis of FORC diagrams focused in isolating the 
contribution of biogenic magnetite with respect of detrital magnetite. Variations in these parameters were tentatively interpreted as variations in the abundance of sediment transportation or origin, and fertilization of the water.

These measurements were performed using a LakeShore Vibrating Sample Magnetometer (VSM)

\subsection{X-Ray Absorption Near-Edge structure (XANES)}

XANES spectra are used to study and quantify the crystalline structure and oxidation of elements. The technique involves the response of electrons of the outer shell of an atom as a function of absorption and re-emission of X-ray photons. (Stern et al. 1983; Konignsberg et al., 1988).

Fe XANES spectra were recorded at the XRF beam line at the Laboratorio Nacional de Luz Sincrotron (National Laboratory of Synchrotron Light), in Campinas, Brazil. A Si single crystal monochromator was used, with X-ray beam spot size of 10 x $20 \mu \mathrm{m}$. Spectra were collected with $0.5 \mathrm{eV}$ energy intervals, with averaging of $4 \mathrm{~s}$ per point from $7090 \mathrm{eV}$ to $7250 \mathrm{eV}$. At least 6 spectra per sample were measured to increase the signal to noise ratio after stacking. The spectra were processed (stacking and smoothing) with the Athena 0.8 software (Solé et al., 2007). Samples of M. australis, originally collected from water from Itaipu Lagoon (Rio de Janeiro, Brazil), were cultivated at the Instituto de Microbiologia at the Universidade Federal de Rio de Janeiro (Brazil), and used as an internal standard to compare the characteristics of uncultivated magnetotactic bacteria separated from sediment samples. The samples were washed with sodium hypochloride and were then dried. Magnetic particles were concentrated and separated from the sediment using rare Earth magnets. The samples were handled in a controlled, nitrogen atmosphere to prevent oxidation of the material. The magnetic fraction was then mounted between two layers of kapton film (with has negligible Fe).

Chapter 3. Biogenic magnetite as a possible indicator of sedimentary chemical stratification: a comprehensive study of sediment from Mamanguá Ría, Brazil.

\subsection{Introduction}

Magnetite produced by MTB has specific characteristics in terms of stoichiometry, crystal structure, morphology, size, and spatial organization (Mann et al., 1984; Egli, 2004b; Kopp 
and Kirschvink, 2008; Yan et al., 2012; Chen et al., 2014). The magnetic properties of biogenic magnetite have been studied extensively in recent years (Moskowitz et al., 1993; Kruiver and Passier, 2001; Egli, 2004b, 2010; Roberts et al., 2011; Jovane et al., 2012; Savian et al., 2014; 2016), which provide a range of ways to recognize and characterize such crystals. Environmental magnetic studies can be a rapid and reliable way to track the spatial distribution of MTB, which has the potential to enable reconstruction of oxygen gradients in natural environments, where other proxies or methods of study are not available.

Many studies have suggested that the frequently identified biogenic soft (BS) and biogenic hard $(\mathrm{BH})$ magnetite types are associated with equant and more elongated morphologies, respectively, and that their abundance varies in accordance with sedimentary oxygen content, where MTB that produce the BH component live in less oxygenated environments (Egli, 2004a, 2004b, 2004c; Yamazaki, 2012; Yamazaki and Shimono, 2013; Chang et al., 2013;

Usui et al., 2017). Despite the potential value of such proxy information, magnetic proxies for $\mathrm{BS}$ and $\mathrm{BH}$ magnetite have not been assessed adequately in relation to direct pore water determinations of sedimentary oxygenation. The aim of this study is to provide a direct test of whether the $\mathrm{BS}$ and $\mathrm{BH}$ magnetite types can be used to provide proxy information about sedimentary oxygenation.

This chapter presents an integrated study of magnetic properties, pore water chemistry, and lithological analyses of surface sediments from a coastal ría environment in the Saco do Mamanguá (Rio de Janeiro (RJ), Brazil). This work represents a comprehensive analysis of the boundary conditions for geological preservation of biogenic magnetite; XANES measurements have been performed on MTB to study the synthesis of biogenic magnetite from a phosphaterich ferric hydroxide precursor (Fdez-Gubieta et al., 2013; Baumgartner et al., 2013, 2016), but no previous analyses have been performed on biogenic magnetite isolated from natural sediment. We use our results from M. australis spectra as an internal standard to compare XANES data from natural isolated magnetic particles from recent sediment from Mamanguá Ría (Ilha Grande Bay, Brazil; Benites et al., 2015) to confirm the presence of MTB and the state of the magnetite they produce. XANES data are integrated with transmission electron microscope (TEM) observations and a range of magnetic measurements.

The main objective is to characterize chemical stratification in the sediment column in a small, enclosed basin, with limited oceanic influx by comparing direct (pore water chemistry, lithology) and indirect (magnetic) methods to assess whether magnetic properties can provide 
proxies for geochemical and oceanographic conditions in the geological record. These results should be helpful in gaining new insights into links between metabolic processes of MTB and their environment.

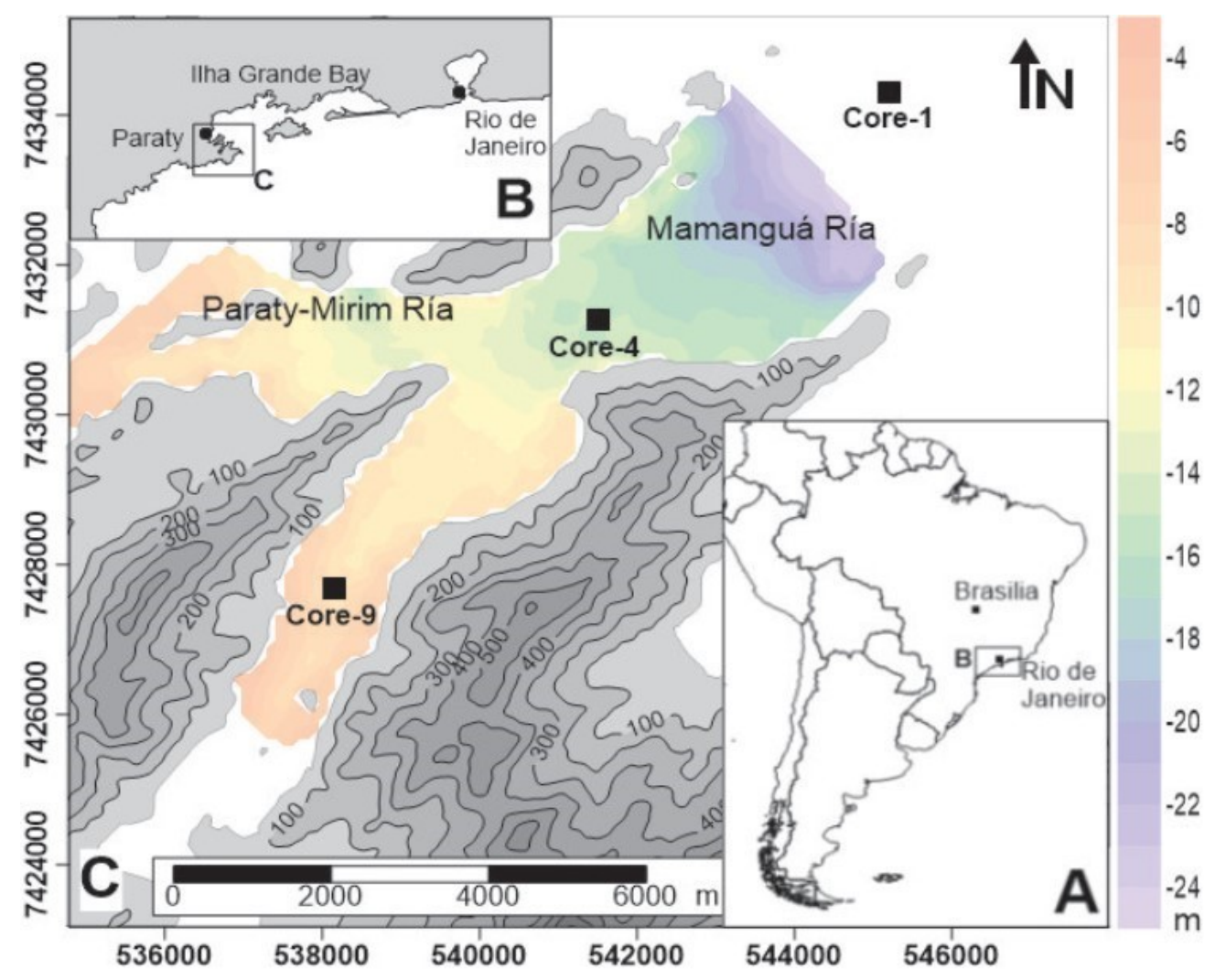

Figure 5 Map of Mamanguá Ría and surrounding areas, with the positions of the three studied sediment cores marked with black squares (modified from Benites et al., 2015)

\subsection{Environmental setting}

Mamanguá is located in Ilha Grande Bay and is part of the Municipality of Paraty (RJ, Brazil). It is elongated ( $\sim 11 \mathrm{~km}$ long and $\sim 2 \mathrm{~km}$ wide) and is flanked by relatively steep mountains (Figure 5). It is, thus, morphologically considered a "ría" (i.e., an ancient river valley drowned due to Holocene sea level rise (Castaing and Gulicher, 1995)). Mamanguá Ría has restricted circulation and low intensity tidal variation, which ranges between 64 and $125 \mathrm{~cm}$ (Bernardes, 1996). The inner ría receives organic matter from land, like in an estuary, while the outer ría is influenced by marine production (Spera, 2012). Surface sediments are predominantly 
composed of clay and silt and are water saturated. High organic phosphorus contents (199-324 $\mathrm{mg} / \mathrm{g}$ ) indicate a significant nutrient supply from local soil erosion (Teixeira, 2009). Gas (possibly methane) seepage has been reported from shallow depths below the seafloor (Benites et al., 2015).

The ría margins are composed of granites linked to the Araçuaí orogen (Almeida, 1977; Pedrosa-Soares et al., 2007). Peraluminous granites are dominant on the NE ría flank, while alkaline granites and gneissic leucogranites crop out on the SW flank. Structurally, the region is characterized by an extensive SW-NE and SE-NW oriented orthogonal fault and fracture system. Atlantic forest covers most of the area and has contributed to formation of extensive lateritic soils.

\subsection{Materials and Methods}

\subsubsection{M. australis culture and microscopy}

M. australis strain IT-1 was cultured in a semisolid, heterotrophic medium using sodium acetate and sodium succinate as carbon sources (Morillo et al., 2014). For whole-mount transmission electron microcope (TEM) observations, cells were deposited directly over formvar-coated 300 mesh copper grids, rinsed with distilled water, air-dried and imaged with a Morgagni TEM (FEI Company, Hillsboro, OR, USA) at $80 \mathrm{kV}$. High-resolution TEM and scanning TEM observations were performed using a FEI TECNAI G2 TEM operated at 200 $\mathrm{kV}$. Energy dispersive X-ray microanalysis was done with a Thermo Scientific silicon drift EDS detector system. Fast Fourier Transform (FFT) spectra were obtained from magnification calibrated images and were indexed using Digital Micrograph software (Gatan Inc.). 3D crystal models were made with the KrystalShaper software (http://www.jcrystal.com/products/krystalshaper/).

$\begin{array}{llccc}\text { site } & \text { latitute S } & \text { longitute W } & \text { water depth } & \begin{array}{l}\text { Table 1 Latitude, longitude, } \\ \text { and water depth of the } \\ \text { analyzed cores. }\end{array} \\ 1 & 23^{\circ} 11^{\prime} 57^{\prime \prime} & 44^{\circ} 33^{\prime} 18^{\prime \prime} & 26.4 & \\ 4 & 23^{\circ} 13^{\prime} 37^{\prime \prime} & 44^{\circ} 35^{\prime} 52^{\prime \prime} & 15.4 & \\ 9 & 23^{\circ} 16^{\prime} 33^{\prime \prime} & 44^{\circ} 38^{\prime} 6^{\prime \prime} & 7.2\end{array}$




\subsubsection{Pore water chemistry}

Pore waters were extracted along the cores at $10 \mathrm{~cm}$ intervals using Rhizon filters (membrane with $0.12-0.18-\mu \mathrm{m}$ pores) connected to a syringe (http://www.rhizosphere.com/rhizons). A maximum of $10 \mathrm{ml}$ of water was extracted for most samples. Soon after collection, $\sim 2 \mathrm{ml}$ of pore water was placed in a transparent glove box with an inert atmosphere for measuring dissolved oxygen (DO) concentration, $\mathrm{pH}$, electrical conductivity (EC), and oxidation-reduction potential (ORP). DO was measured with a DO probe connected to a VWR sympHony benchtop meter, while $\mathrm{pH}, \mathrm{EC}$, and ORP were measured with a HACH SensION portable meter. Pore water sampling was performed with rhizons (polymer filter with $0.1 \mu \mathrm{m}$ pore size; SeebergElverfeldt et al., 2005). Every $10 \mathrm{~cm}$, holes were drilled into the core liners. All samples were filtered and diluted to $10 \mathrm{ml}$ with $\mathrm{HNO}_{3} 5 \%$ solution in ultrapure water (Milli-Q) and were analyzed using inductively coupled plasma optical emission spectrometry (ICP-OES).

\subsubsection{Mineralogy, grain size, and physical properties}

Samples were prepared for powder X-ray diffraction (XRD) analysis at $10 \mathrm{~cm}$ stratigraphic intervals (40 samples were analyzed). Samples were prepared by crushing and pulverizing $\sim 0.2 \mathrm{~g}$ of bulk sediment in a mortar. Samples were analyzed with an Olympus ${ }^{\circledR}$ BTX diffractometer using Co-K radiation, operated at $30 \mathrm{kV}$ and $0.326 \mathrm{~mA}$, over the $2 \theta$ range of $5-60^{\circ}$, with a step size of $0.05^{\circ}$ and 60 exposures. Mineral identification and analysis was carried out using the XPowder software (Version 2010.01.15 PRO), which uses the PDF-2 International Centre for Diffraction Data (ICDD) database. XRD identification criteria are based on Biscaye (1965), Moore and Reynolds (1989), and Hillier et al. (2003). Semi-quantitative analyses were performed through the reference intensity ratio (RIR) method, which is based on scaling all data to diffractions from standard reference materials, according to Chung (1974). About $5 \mathrm{~g}$ of sample from $10 \mathrm{~cm}$ stratigraphic intervals were used for grain size analyses. Samples were treated with $10 \%$ hydrogen peroxide to remove organic matter, and with $0.05 \mathrm{~g}$ of pyrophosphate added to each sample to avoid clay mineral flocculation. The measurements were performed with a Bluewave Microtrac system.

Petrophysical properties of core 9 were measured using a GEOTEK multisensor core logger (MSCL), equipped with piezo-electric ceramic transducer for P-wave velocity measurements, Bartington loop sensor for magnetic susceptibility, and natural gamma-ray counters for natural gamma-ray spectroscopy, density and porosity measurements. 


\subsection{Results}

\subsubsection{Age model}

An age model for core 9 was constructed using ${ }^{14} \mathrm{C}$ datings (Figure 6). Sediments from the bottom of the core were deposited at 3,720 yr B.P. Ages calculated from all dated samples lie on an almost straight line $\left(\mathrm{R}^{2}=0.984\right)$, where the sedimentation rate averages $0.11 \mathrm{~cm} / \mathrm{yr}(1.1$ m/kyr). (data courtesy of Flaminia Cornaggia)

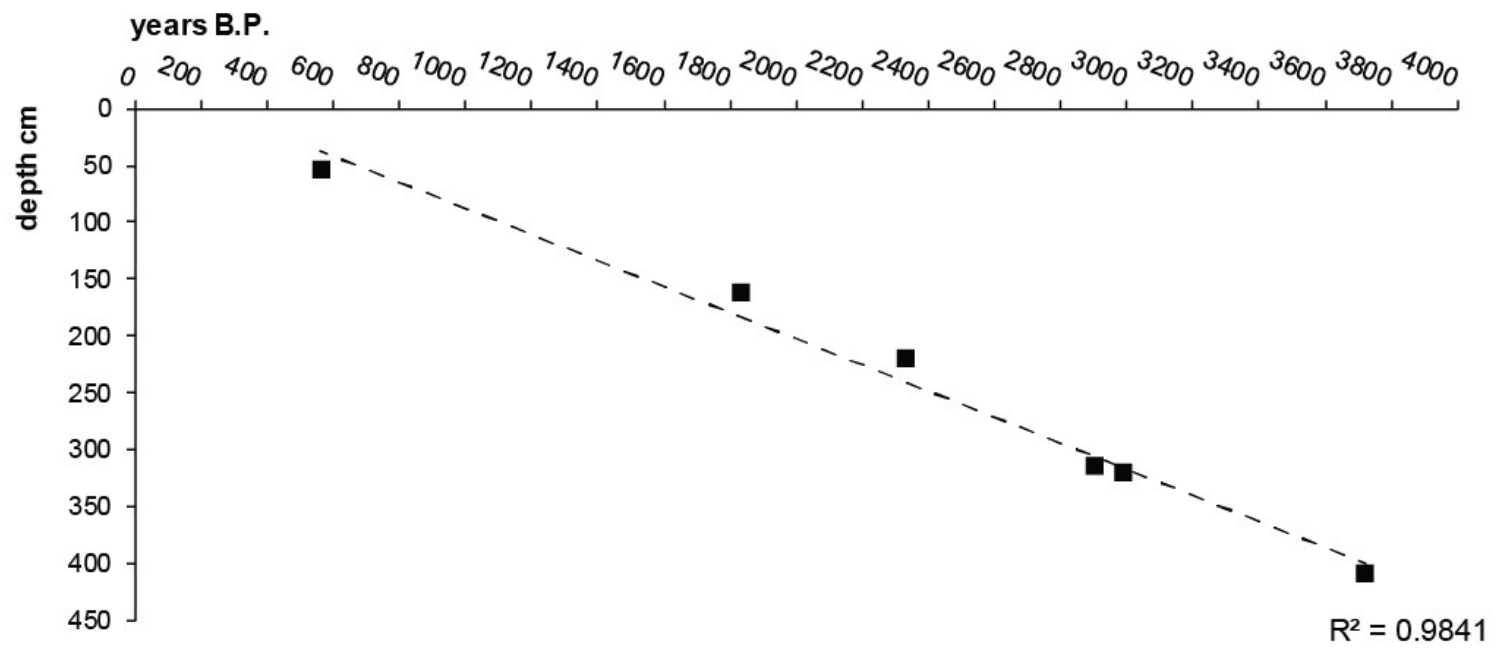

Figure 6 Age model for core 9 based on ${ }^{14} \mathrm{C}$ dating. Ages are Years Before Present

\subsubsection{Environmental and rock magnetism}

Down-core environmental magnetic variations for core 9 indicate high NRM, ARM, and IRM values in the uppermost $35 \mathrm{~cm}$ of the core (Figure $7 \mathrm{~b}-\mathrm{d}$ ). Parameter values then drop abruptly and maintain almost constant and low values, decreasing by a factor of 10 to 100 . The S-ratio (Figure 7e) gives information about the relative concentration of high and low coercivity minerals. Its mean value for the uppermost $35 \mathrm{~cm}$ is 0.97 , below which it drops to 0.4 at 40 $\mathrm{cm}$, and then returns to values of $\sim 0.8$ throughout the core. S-ratio values are consistent with the dominance of magnetite, except at $40 \mathrm{~cm}$, which is consistent with a dominance of hematite (Bloemendal et al., 1992; Frank and Nowaczyk, 2008). HIRM (Figure 7f), which provides information about the absolute concentration of high coercivity minerals, has similar characteristics to NRM, susceptibility, ARM, and IRM. Consistently high values of NRM, 
ARM, and IRM, indicate high magnetic mineral concentrations. ARM/IRM is sensitive to magnetic grain size and high values indicate a high fraction of SD to coarser particles (Evans and Heller, 2003). The magnetic property shift below $40 \mathrm{~cm}$ is consistent with rapidly decreasing magnetic mineral concentrations and increased magnetic particle sizes. S-ratio and magnetic grain size variations suggest that the transition is marked by increased relative contributions of high coercivity minerals (e.g., hematite).

IRM acquisition curves for discrete samples have different behavior above and below depths of 30-40 cm (Figure 8). Above this depth, samples can be fitted with four components: one has low coercivity (average $8 \mathrm{mT}$ ) and high dispersion $(0.31)$ that contributes $10 \%$ of the total signal and is interpreted to be detrital magnetite, or possibly the result of thermal activation of a superparamagnetic component within a broader SD distribution (Heslop et al., 2004,). A component with high coercivity $(242 \mathrm{mT})$ and high dispersion $(0.25)$ is interpreted to be hematite, which contributes $<4 \%$ of the magnetic signal. Two medium-coercivity components have values consistent with biogenic magnetite (mean coercivity of $32 \mathrm{mT}$ and dispersion of 0.23 , and mean coercivity of $61 \mathrm{mT}$ and dispersion of 0.15 ), which together account for $>84 \%$ of the magnetic signal of these samples. These components are assumed to represent the soft and hard biogenic magnetite components, respectively, of Egli (2004b, 2004c). Below depths of 30-40 cm, samples are more variable in terms of magnetic component characteristics and number of components. The medium coercivity components have higher dispersion $(>0.24)$, which indicates that the magnetite is either not biogenic or that the magnetite crystals have undergone some kind of alteration. The hematite contribution increases with depth up to about $40 \mathrm{~cm}$, and in some samples, a second high coercivity component appears, with a mean contribution of $8 \%$. Decomposition of IRM acquisition curves for samples from depths below $35 \mathrm{~cm}$ in the core can be non-trivial because of the weak magnetization and higher signaltonoise ratio due to the low magnetic mineral concentrations.

IRM components in samples from cores 1 and 4 are similar to those from core 9. Above the key transition depths $(10 \mathrm{~cm}$ and $30 \mathrm{~cm}$, respectively), samples were fitted with two components, one with low coercivity $\left(\mathrm{B}_{1 / 2}\right.$ of $\left.14 \mathrm{mT}\right)$ and one with medium coercivity $\left(\mathrm{B}_{1 / 2}\right.$ of $43 \mathrm{mT}$ ) and low DP values, with the medium coercivity component contributing almost $80 \%$ of the IRM. Below these depths, samples are more variable, with a third high coercivity component $\left(\mathrm{B}_{1 / 2}\right.$ of $\left.320 \mathrm{mT}\right)$ that contributes $>40 \%$ of the signal. The medium coercivity component has higher $\mathrm{B}_{1 / 2}$ values in these samples, with a mean of $60 \mathrm{mT}$. The low coercivity 
component can be interpreted as coarse detrital magnetite (Egli, 2004a; Savian et al., 2014). Coercivity and DP values for the second component are consistent with the narrow grain-size range of biogenic magnetite produced in-situ by magnetotactic bacteria (Kruiver and Passier, 2001; Egli, 2004b, 2004c; Roberts et al., 2012; Jovane et al., 2012; Savian et al., 2014). The higher DP and coercivity distribution of this component below 30-40 cm may be due to alteration of biogenic magnetite. The high coercivity component values are consistent with the presence of hematite. 


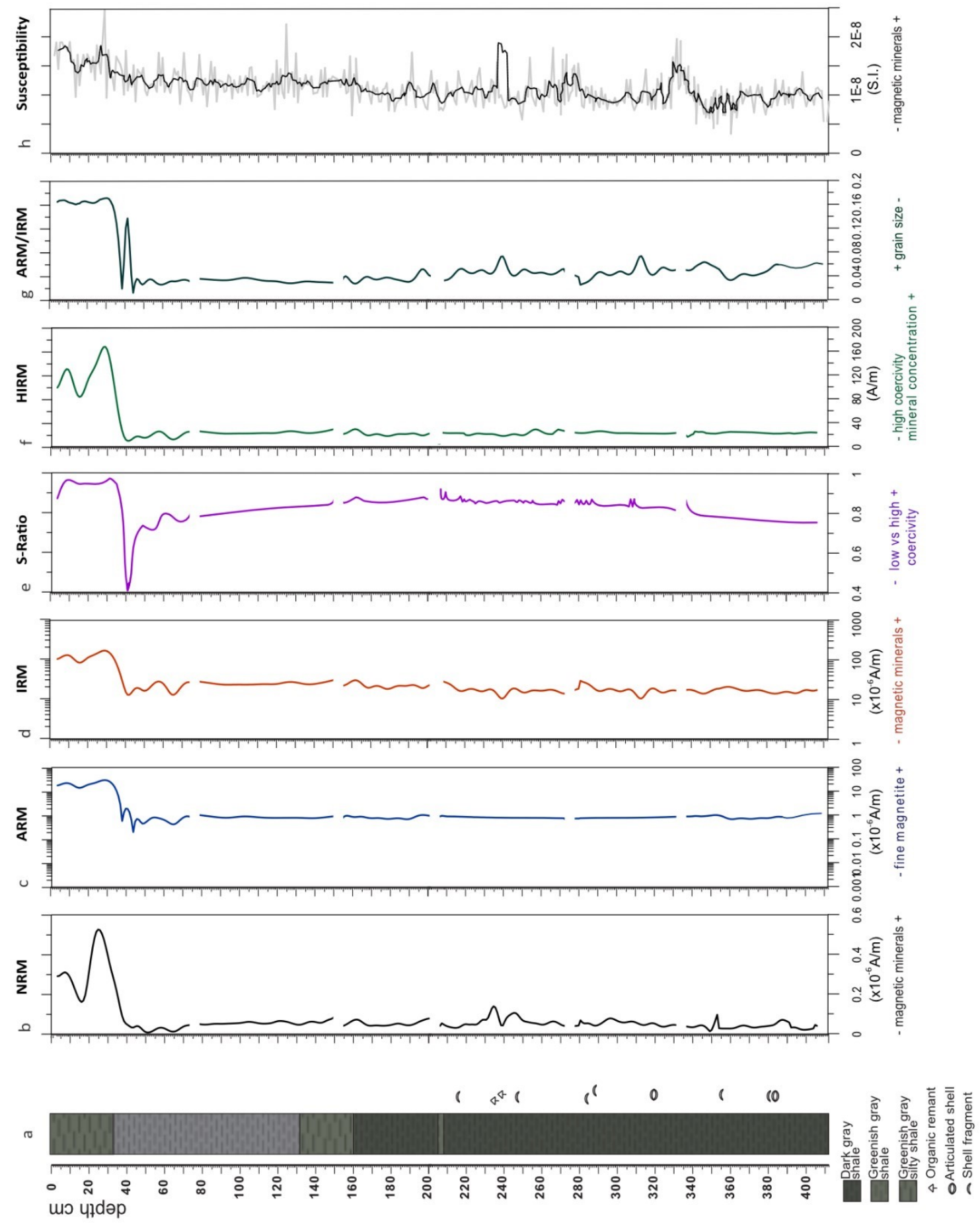

Figure 7 (previous page) Down-core magnetic parameter variations for core 9. (a) Lithological log, (b-h) environmental magnetic parameters. In (h) the raw magnetic susceptivity values are represented by the grey line, 
while the black line is the running average (period 3); (b-g) measured on u-channel, (h) measured on discrete samples with $1 \mathrm{~cm}$ spatial resolution.

Thermomagnetic curves for the four uncultivated samples are shown in Figure 9. An increase in magnetic susceptibility during heating from 20 to $250^{\circ} \mathrm{C}$ is interpreted as due to maghemite. The height of the peak increases with increasing depth, which suggests an increasing concentration of maghemite with depth. A sharp magnetic susceptibility decrease is visible at $571-581{ }^{\circ} \mathrm{C}$, which is due to magnetite (Thompson and Oldfield, 1986). The absence of a small susceptibility increase near the peak expected for pure magnetite (Hopkinson effect) suggests the absence of $\mathrm{Ti}$ in the magnetite structure (Lattard et al., 2006), as expected for stochiometrically pure biogenic magnetite.

Hysteresis loops have low coercivities that are typical of magnetite (e.g., Dunlop and Özdemir, 1997). $M_{r}$ and $M_{s}$ vary with similar trends as the magnetic concentration-dependent parameters in Figure 2, with high values above $35 \mathrm{~cm}$ and lower values below, while $\mathrm{B}_{\mathrm{c}}$ decreases to a minimum at $40 \mathrm{~cm}$ and then increases down-core to reach similar values as in the upper part of the core at about $100 \mathrm{~cm}$ (Figure 10a, b, c). Coercivity and magnetization parameters for cores 1 and 4 have similar behavior and parameter values as core 9 , with minimum values at depths of $10 \mathrm{~cm}$ and $30 \mathrm{~cm}$, respectively. Coercivity increases again to reach similar values to those of surficial sediments below these depths.

High-resolution FORC diagrams for selected samples from core 9 (Figure 11) have a distinct narrow horizontal central ridge that extends from near $\mathrm{B}_{\mathrm{c}}=0$ to maximum values at $\sim 30-40$ $\mathrm{mT}$, with negligible magnetostatic interactions (vertical axis). This ridge is prominent only in the uppermost $35 \mathrm{~cm}$ of the core. FORC diagrams for samples from cores 1 and 4 contain a similar central ridge for samples from the uppermost parts of the cores, which disappear at depths of $10 \mathrm{~cm}$ and 30, respectively (Figure 14, Figure 15). Below this depth, only a superparamagnetic (SP) component is visible (cf. Pike et al., 2001).

FORC diagrams for biogenic magnetite extracted from sediment have a wider coercivity distribution than for the cultivated sample, which implies that the sediment contains more than one type of MTB, because each species produces slightly different kinds of biogenic magnetite, with each MTB species synthesizing magnetic particles with specific crystal geometry (e.g. Faivre et al., 2008; Popa et al., 2009). 

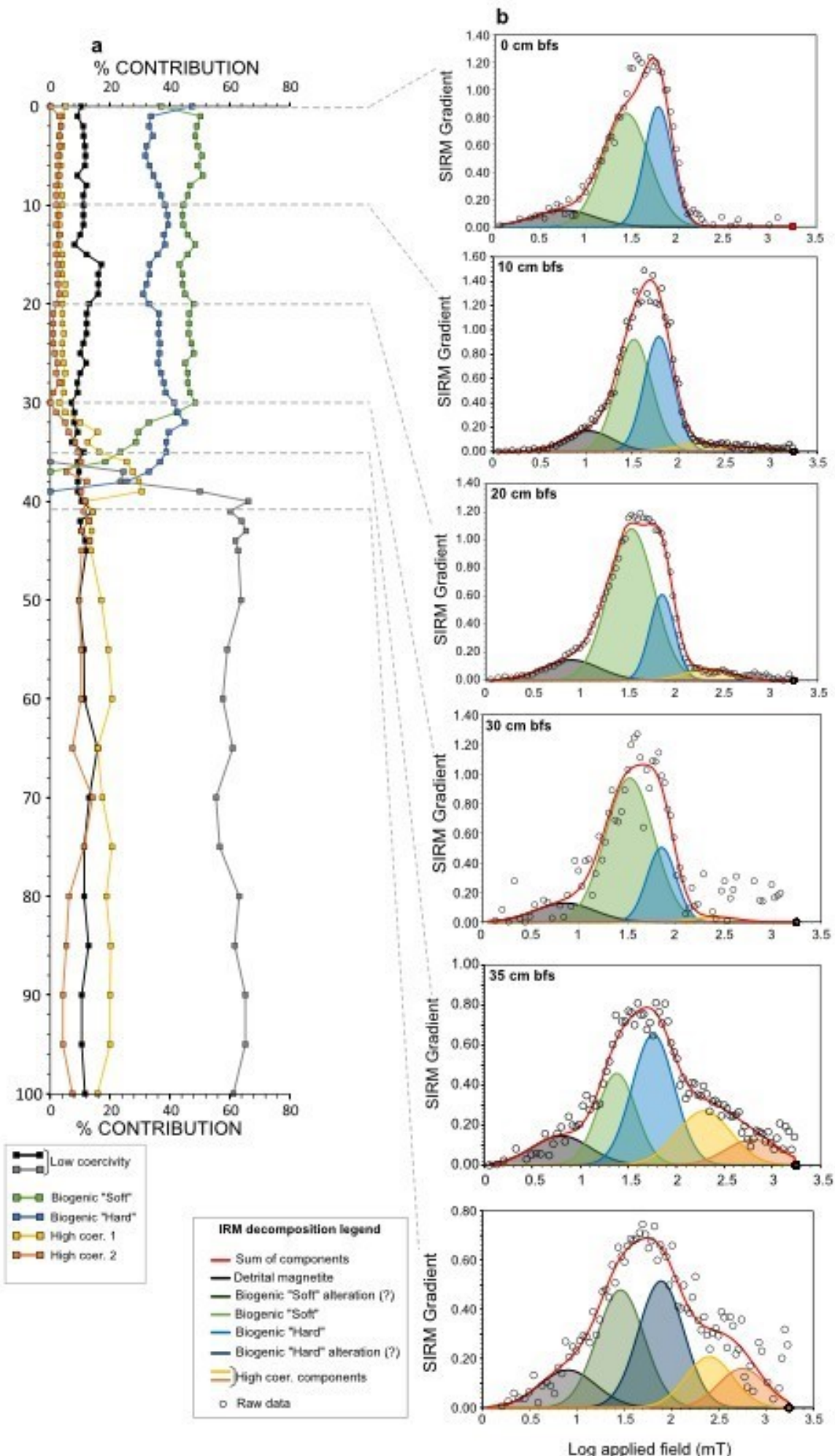

Figure 8 Relative concentrations of magnetic minerals for the uppermost $90 \mathrm{~cm}$ of core 9 from decomposition of IRM acquisition curves. (b) Gradient of IRM acquisition curves for representative samples at key depths; the raw data become increasingly noisy toward lower depths due to low magnetic mineral concentrations. 

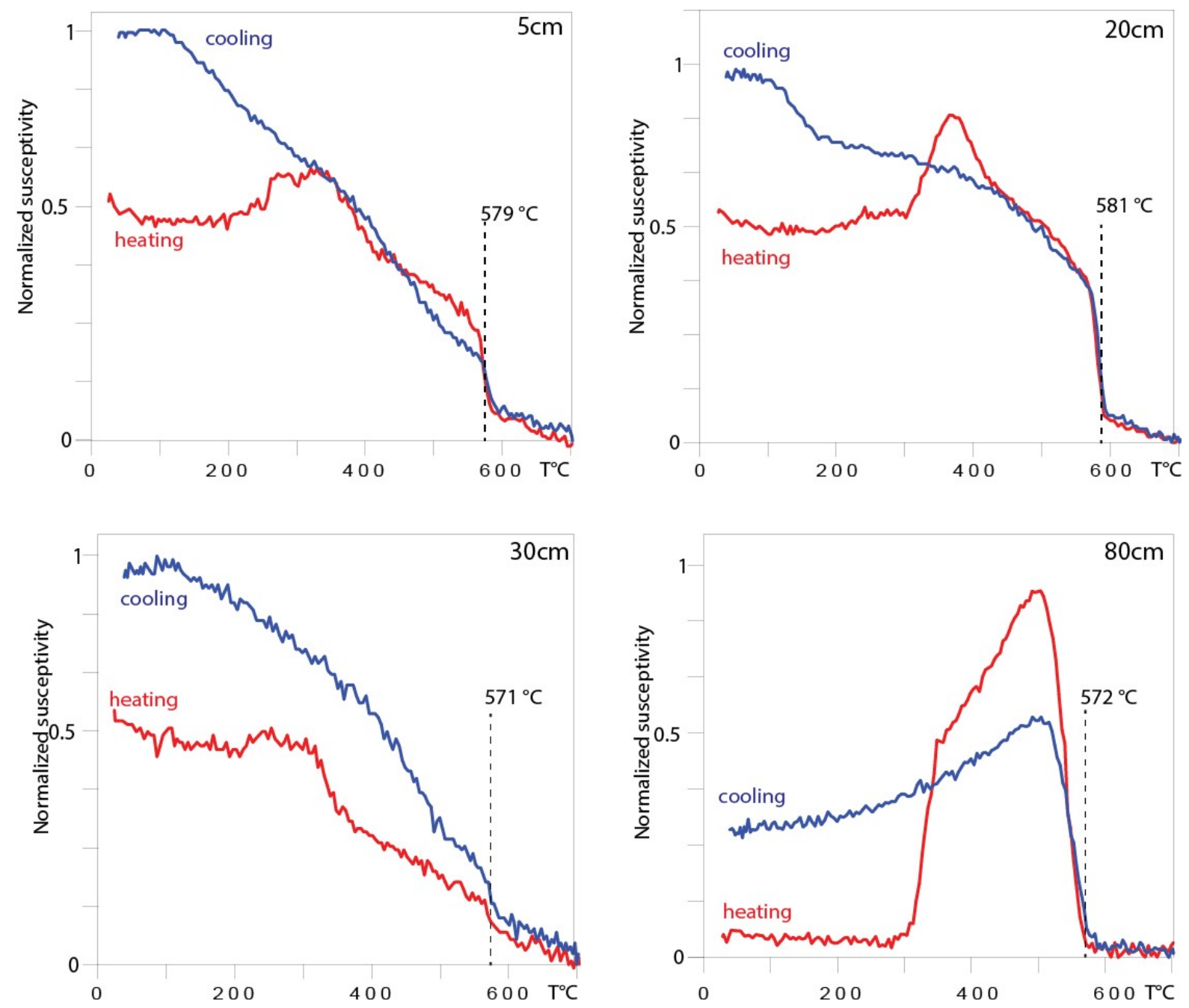

Figure 9 Thermomagnetic curves for the four samples from Mamanguá Ría. The red (blue) curves represent the heating (cooling) portions of the measurement. The indicated Curie temperature is relative to magnetite.

PCA analyses for the FORC dataset are reported in Figure 10d-f. The total low-resolution FORC signature can be divided into two end-members: one (EM 1) is consistent with noninteracting biogenic magnetite and a second (EM 2) represents SP material of probable detrital origin. Down-core variations of the two EMs are consistent with the observation that an important change occurs at depths of 10,30, and $35 \mathrm{~cm}$ in cores 1, 4, and 9, respectively. Above these depths, the major constituent is biogenic magnetite, which makes up $80 \%$ of the magnetic signal. Below these depths, the biogenic magnetite signal disappears abruptly, and only a SP component remains. Absolute values for each PCA EM and the total magnetization intensity indicate that, while the biogenic component disappears with increasing depth, the SP component is almost constant along the three cores. In addition, detrital magnetic mineral 
abundances are higher for core 1 than for cores 4 and 9, which suggests that detrital input is higher in the outer part of the Mamanguá Ría, and that the waters of the internal part are relatively isolated from Ilha Grande Bay.
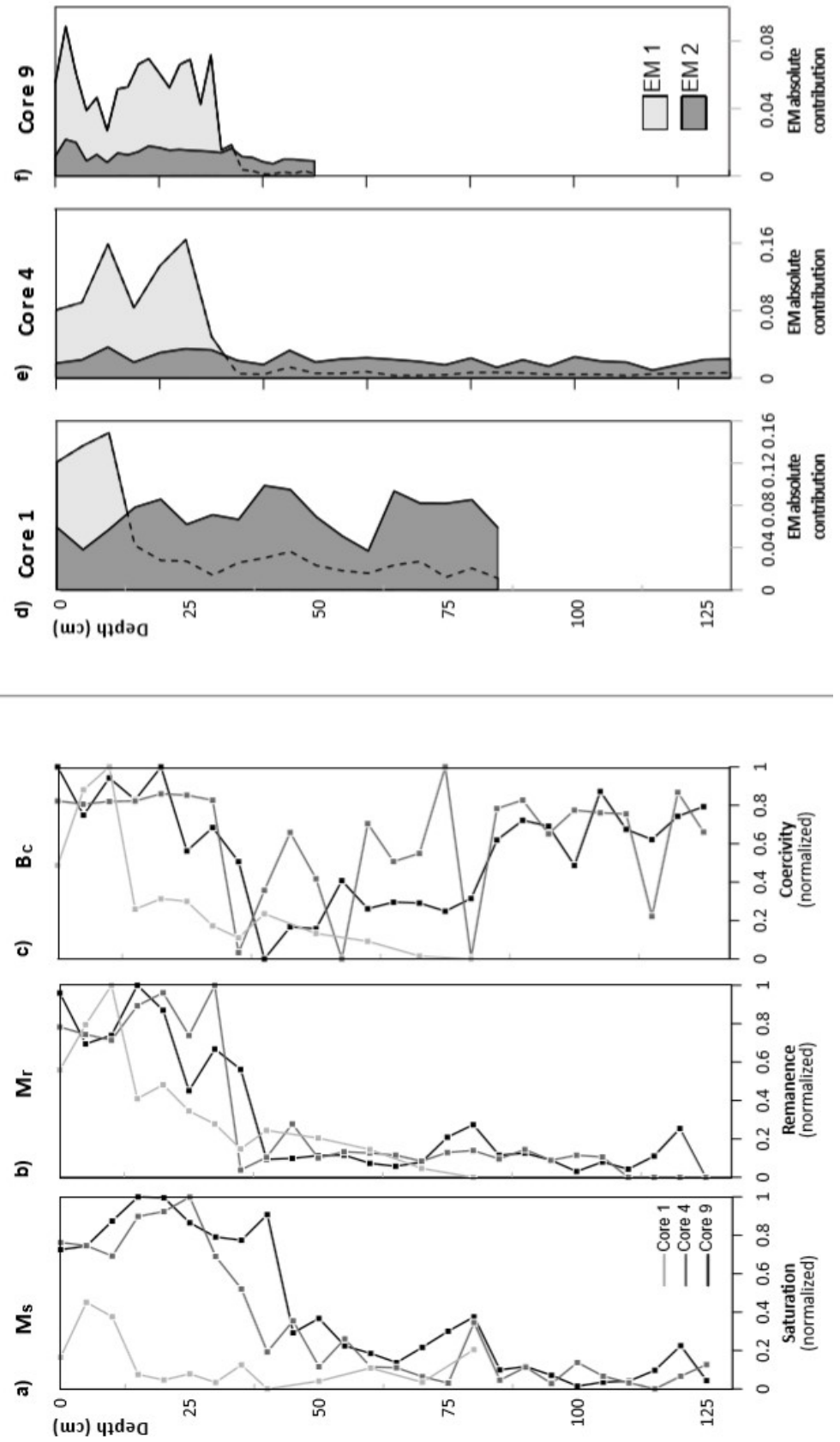

Figure 10 (previous page) Normalized values of rock magnetic properties of cores 1, 4, and 9: (a) Magnetic saturation (Ms), (b) magnetic remanence (Mr), (c) magnetic coercivity (Bc). (d to f) Principal component analysis of low-resolution FORC diagrams for the three cores, expressed as absolute contribtion relative to total magnetization: EM 1 represents noninteractic, SD magnetite, EM 2 represents interacting SP detrital magnetite.

\subsubsection{TEM observations of MTB}


Magnetofaba australis strain IT-1 cells are coccoid to ovoid in morphology (Figure 12 a). Each cell contains a single chain of less than 10 magnetosomes (Figure $12 \mathrm{a}$, white arrows) and amorphous granules (Figure 12 a) that are enveloped by a thin membrane (Figure 12 b, black arrows). High resolution transmission electron microscope (HRTEM) observations of whole mount cells were used to determine the mineral structure of the magnetosome crystals (Figure $12 \mathrm{c}$ ). Fast Fourier Transform (FFT) spectra were indexed based on a standard cubic system and are consistent with magnetite $\left(\mathrm{Fe}_{3} \mathrm{O}_{4}\right)$, following previous determinations (Morillo et al., 2014). Magnetosome morphology 111 was modelled using HRTEM data and was determined to be elongated octahedral magnetite (Figure $12 \mathrm{~d}$ ).

TEM observations of uncultivated MTB that were concentrated magnetically from Mamanguá sediments indicate the presence of at least four cell morphotypes (Figure $12 \mathrm{f}-\mathrm{i}$ ). MTB with coccoid to ovoid forms contain elongated octahedral (Figure $12 \mathrm{f}$ ) and cuboctahedral magnetosomes (Figure $12 \mathrm{G}$ ), a vibrioid cell with elongated cuboctahedral particles (Figure 12 h), and a spirillum with prismatic elongated magnetosomes (Figure 12 i) was observed at different depths in the samples. HRTEM imaging of the spirillum magnetosomes (Figure 12 e) indicates that the magnetite crystals are elongated along the $<111>$ crystallographic direction. Energy Dispersive X-ray microanalysis (EDS) confirms the presence of oxygen and iron in the magnetosomes (Figure $12 \mathrm{j}$ ). 
M. australis
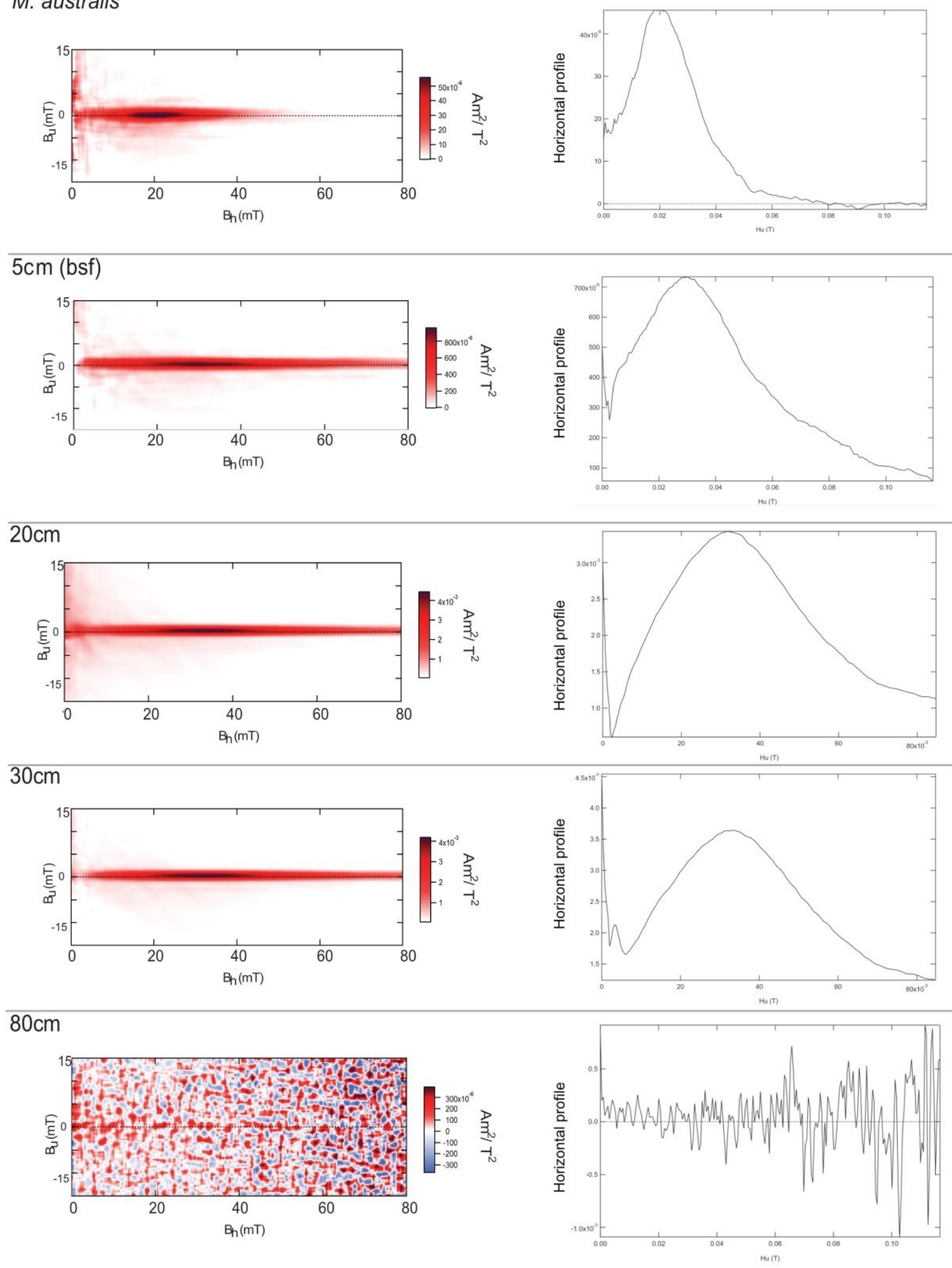

Figure 11 High resolution FORCs for cultivated Magnetofaba australi and four selected samples from Core 9, with the respective horizontal section (traced through $\mathrm{Bu}=0 \mathrm{mT}$ ). 


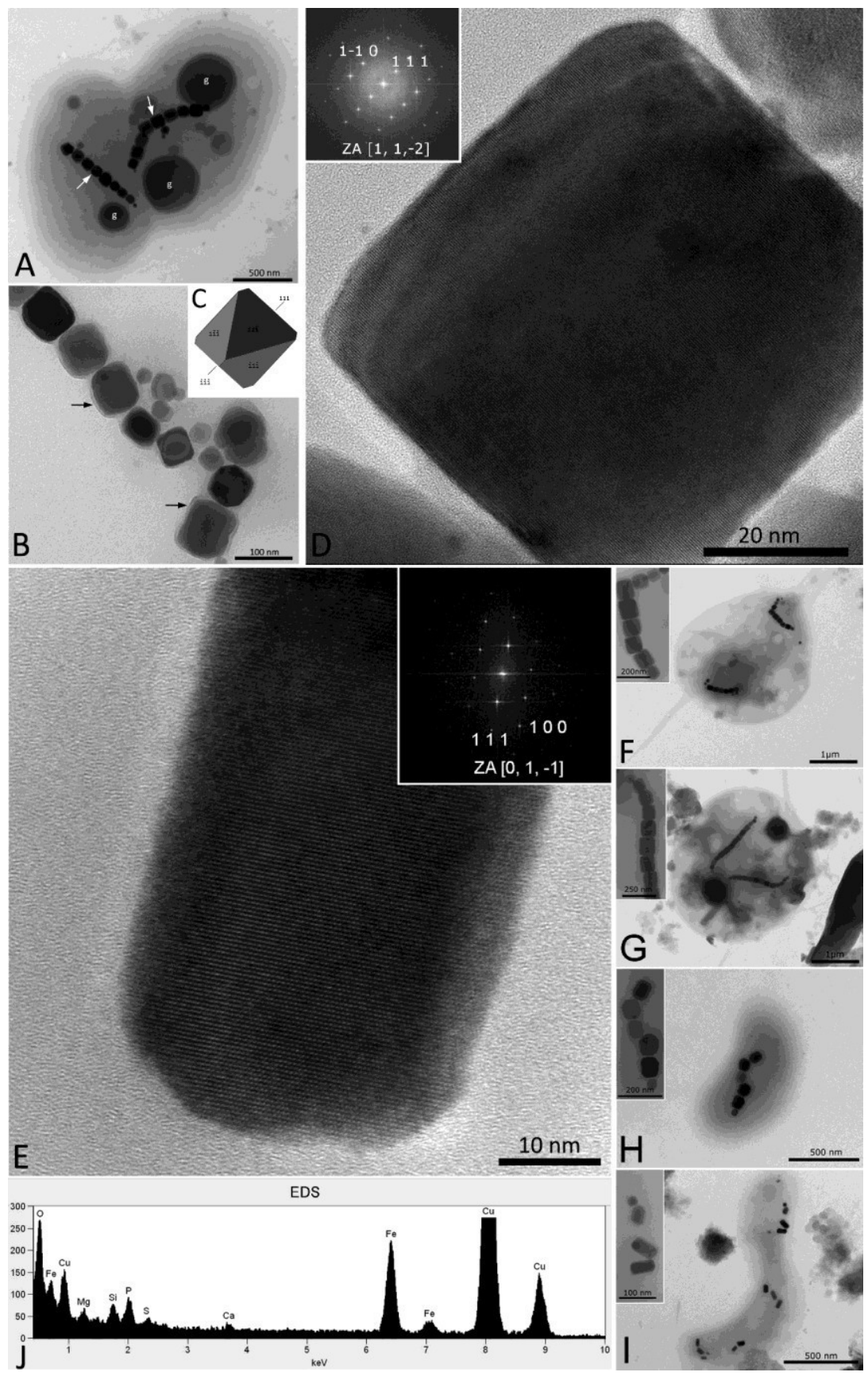

Figure 12 (A) TEM images of two M. australis strain IT-1 bacteria, with white arrows pointing to the magnetite chains (' $\mathrm{g}$ ' represents granules). (B) Detail of a magnetite chain, with black arrows indicating the magnetosome membrane. (C) HRTEM image and a Fast Fourier Transform (FFT at the top left) of a M. australis strain IT-1 magnetosome, with a well-defined octahedral crystal elongated in the 111 direction along the [1, 1, -2] zone axis. (D) 3D model of the elongated octahedral crystal in C. (E) HRTEM image, and FFT (top right) of a spirillum magnetosome, with a well-defined magnetite prismatic crystal elongated in the 111 direction along the [0, 1, -1] zone axis. (F, G, H, I) Different morphologies of uncultivated magnetotactic bacteria from Mamanguá sediments: ' $\mathrm{F}$ ' and ' $\mathrm{G}$ ' are coccoid to ovoid forms, ' $\mathrm{H}$ ' is a vibrioid and ' $\mathrm{I}$ ' is a spirillum form. (J) Energy-dispersive spectroscopy (EDS) of magnetosome crystal with large $\mathrm{O}$ and Fe peaks that confirm a magnetite (Fe3O4) crystal. 

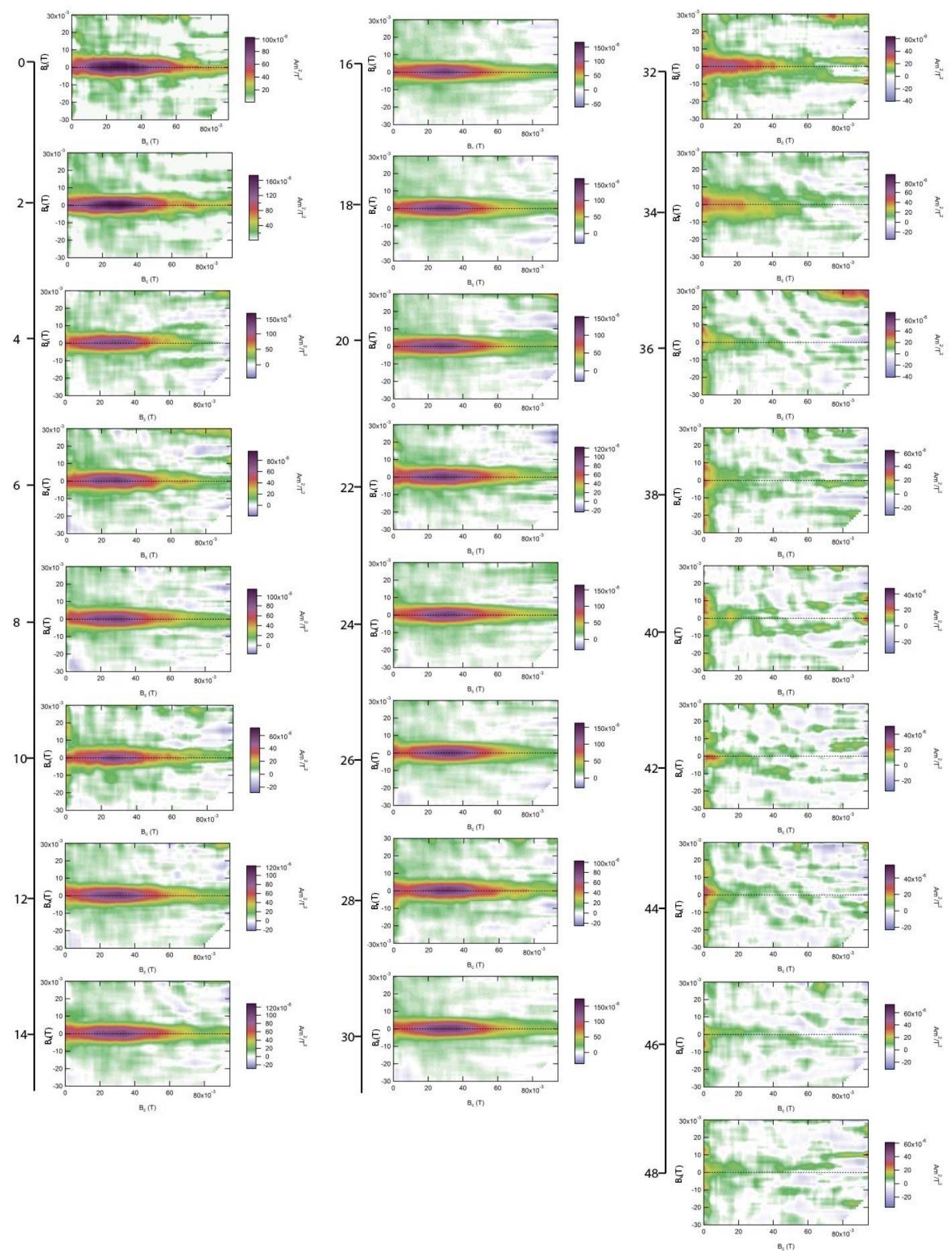

Figure 13 Low-resolution FORC diagrams of samples from core 9, used for FORC-PCA analysis. Measurement parameters are: $\mathrm{H}_{\mathrm{c} 1}=0 \mathrm{mT}, \mathrm{H}_{\mathrm{c} 2}=110 \mathrm{mT} ; \mathrm{H}_{\mathrm{u} 1}=-15 \mathrm{mT}, \mathrm{H}_{\mathrm{u} 2}=+15 \mathrm{mT}, 100$ FORCs 


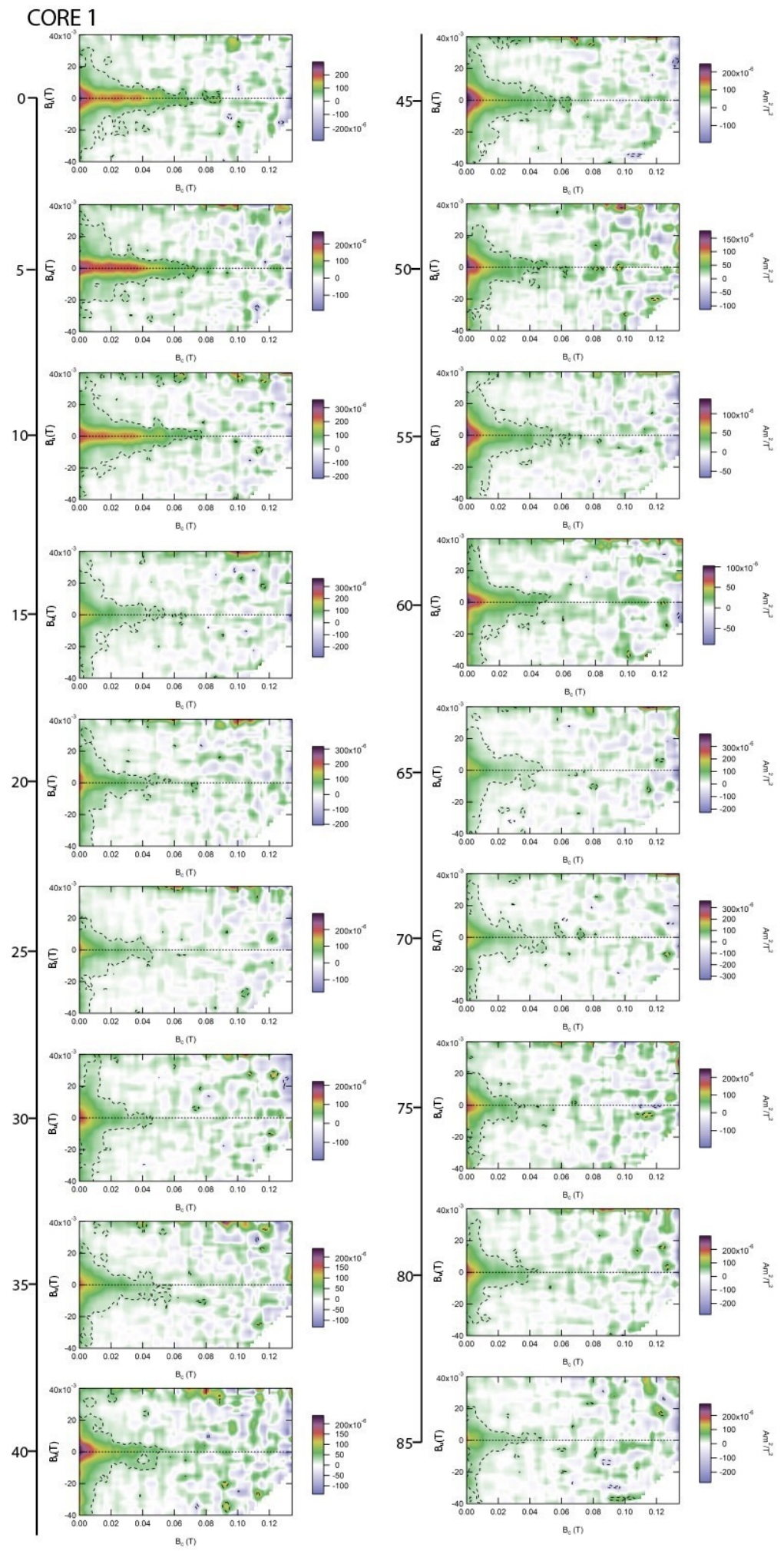

Figure 14 Low-resolution FORC diagrams of samples from core 1, used for FORC-PCA analysis. Measurement parameters are: $\mathrm{H}_{\mathrm{c} 1}=0 \mathrm{mT}, \mathrm{H}_{\mathrm{c} 2}=110 \mathrm{mT} ; \mathrm{H}_{\mathrm{u} 1}=-15 \mathrm{mT}, \mathrm{H}_{\mathrm{u} 2}=+15 \mathrm{mT}, 100$ FORCs. 
CORE 4
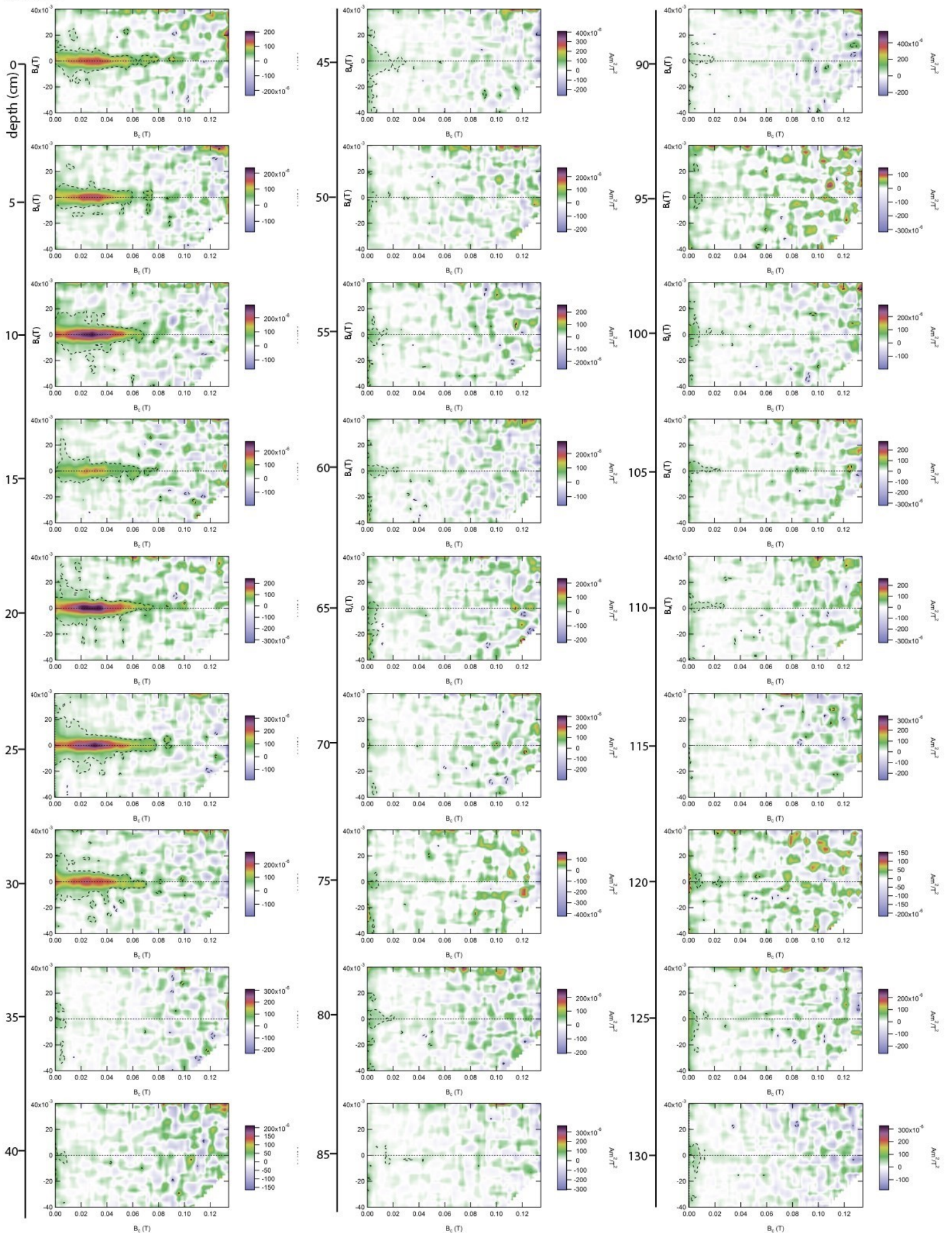

Figure 15 Low-resolution FORC diagrams of samples from core 4, used for FORC-PCA analysis. Measurement parameters are: $\mathrm{H}_{\mathrm{c} 1}=0 \mathrm{mT}, \mathrm{H}_{\mathrm{c} 2}=110 \mathrm{mT} ; \mathrm{H}_{\mathrm{u} 1}=-15 \mathrm{mT}, \mathrm{H}_{\mathrm{u} 2}=+15 \mathrm{mT}, 100$ FORC

\subsubsection{XANES spectra}


XANES spectra for M. australis (Figure 16 a) contain characteristic features of magnetite, with a pre-edge peak centered at $7114 \mathrm{eV}$. The structure is due to the $1 s$ to $\square d$ quadrupole transition, which indicates the presence of tetrahedrally coordinated Fe ions (Wilke et al., 2001, Balasubramanian et al., 2014). A strong principal peak at $7131 \mathrm{eV}$, and a smaller one at 7146 $\mathrm{eV}$ are present; these features are consistent with the findings of Baumgartner et al. (2013). The secondary peak $(7146 \mathrm{eV})$ has been recognized in compounds with $\mathrm{Fe}^{3+}$ in octahedral coordination (Voegelin et al., 2010). XANES spectra for samples from increasing sediment depths have some degree of variation (Figure $16 \mathrm{~b}$ ). The sample from a depth of $0.05 \mathrm{mbsf}$ has well-developed peaks at 7114, 7131, and $7146 \mathrm{eV}$ (black arrows in Figure 16 b). The intensity of the peak at $7114 \mathrm{eV}$ is lower and is shifted slightly to the right for samples from depths of 0.20 and $0.30 \mathrm{mbsf}$, which indicates a transition from tetrahedrally to octahedrally coordinated $\mathrm{Fe}$. This suggests that the crystals have undergone a partial structural reorganization. The peaks at 7131 and $7146 \mathrm{eV}$ are also shifted slightly to higher energies, and the secondary peak for the sample at $0.30 \mathrm{mbsf}$ has almost disappeared. These features indicate that some $\mathrm{Fe}^{2+}$ ions have been oxidized to $\mathrm{Fe}^{3+}$. The sample from $0.80 \mathrm{mbsf}$ no longer has a peak at $7146 \mathrm{eV}$, and the main peak is shifted to $7136 \mathrm{eV}$, which indicates further Fe oxidation. The peak at $7114 \mathrm{eV}$ is barely visible for this sample, and is shifted to $7116 \mathrm{eV}$, which indicates that the tetrahedraloctahedral structural transition is more pronounced here (Table 2. These shifts and transitions to a more octahedral structure indicate partial maghemite formation. In addition, the relative height of the pre-edge peak has been correlated with structural disorder (Joseph et al., 2010), which suggests that the oxidation has led to partial reorganization of the crystal structure.

The shift of XANES peaks to higher energies as biogenic magnetite oxidizes is consistent with the results of Baumgartner et al. (2013), who related the shift to a greater $\mathrm{Fe}^{3+}$ content in mixed valence magnetite. 
a)

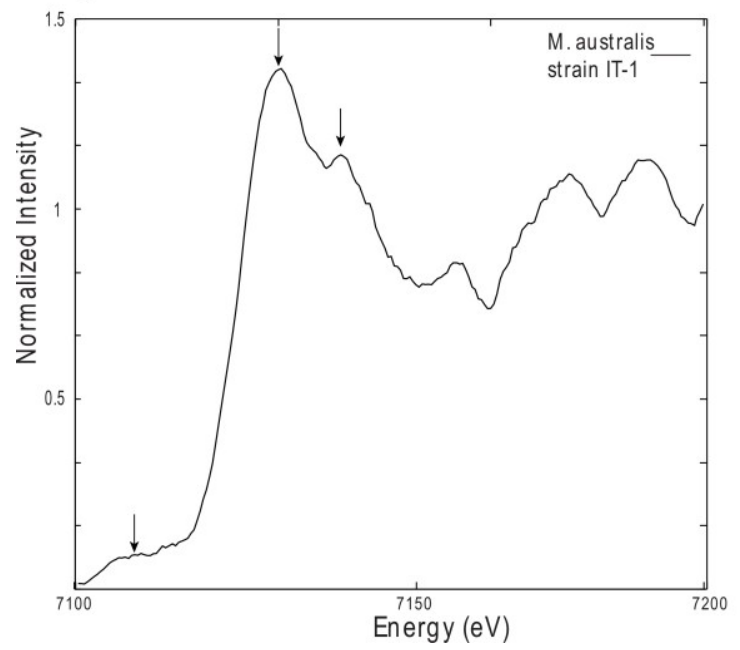

b)

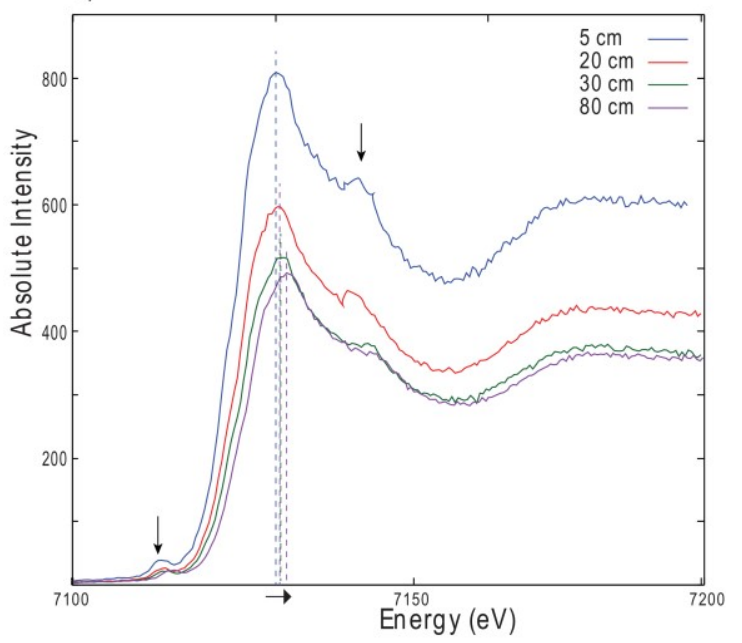

Figure 16 (a) XANES spectrum for Fe of cultivated specimens os Magnetofaba australis; the black arrows point to the feature peaks that were used for the comparison with uncultivated samples extracted from the sediment (b), the dotted vertical lines indicate the position in energy of the main peak of each sample, and their shift towards increasing energies with increasing depth.

\begin{tabular}{|c|c|c|c|c|c|c|}
\hline \multirow[t]{2}{*}{ SAMPLE } & \multicolumn{2}{|c|}{ XANES } & \multirow{2}{*}{$\begin{array}{c}\text { FORC } \\
\text { peak coercivity } \\
m T\end{array}$} & \multicolumn{3}{|c|}{ IRM } \\
\hline & $\begin{array}{c}\text { pre-edge } \\
\mathrm{eV}\end{array}$ & $\begin{array}{l}\text { edge } \\
\mathrm{eV}\end{array}$ & & component & $\begin{array}{c}\text { coercivity } \\
m T\end{array}$ & mean amplitude \\
\hline M. australis & 7114 & 7131 & 20 & & & \\
\hline \multirow[t]{2}{*}{$5 \mathrm{~cm}$} & \multirow[t]{2}{*}{7114} & \multirow[t]{2}{*}{7131} & \multirow[t]{2}{*}{30} & comp. S & 28.2 & 0.24 \\
\hline & & & & comp. H & 61.7 & 0.18 \\
\hline \multirow[t]{2}{*}{$20 \mathrm{~cm}$} & \multirow[t]{2}{*}{7114} & \multirow[t]{2}{*}{7131.5} & \multirow[t]{2}{*}{33} & comp. S & 33.1 & 0.24 \\
\hline & & & & comp. H & 69.2 & 0.13 \\
\hline \multirow[t]{2}{*}{$30 \mathrm{~cm}$} & \multirow[t]{2}{*}{7115} & \multirow[t]{2}{*}{7132.5} & \multirow[t]{2}{*}{35} & comp. S & 33.1 & 0.25 \\
\hline & & & & comp. H & 70.7 & 0.15 \\
\hline \multirow[t]{2}{*}{$80 \mathrm{~cm}$} & \multirow[t]{2}{*}{7116.5} & \multirow[t]{2}{*}{7133.8} & \multirow[t]{2}{*}{-} & comp. 1 & 23.9 & 0.43 \\
\hline & & & & comp. 2 & 138.4 & 0.11 \\
\hline
\end{tabular}

Table 2 Energy of the main XANES peaks, main coercivity peak of the FORC distribution, and coercivity values and mean amplitude of coercivity spectra obtained from IRM acquisition curve decomposition. Note: comp. S: soft biogenic magnetite; comp H.: hard biogenic magnetite; comp. 1: low-coercivity detrital magnetite; comp.2: high coercivity detrital hematite 


\subsubsection{Pore water chemistry}

Pore water chemistry was analyzed on longer gravity cores from Site $4(210 \mathrm{~cm})$ and on a shorter core from Site $9(170 \mathrm{~cm})$ because vibracoring is likely to disturb the sedimentary pore water zonation. DO and ORP for the two cores (Figure $17 \mathrm{a}-\mathrm{b}$ ) have higher values in the uppermost $35 \mathrm{~cm}$ to $45 \mathrm{~cm}$ and lower values in the lower part of the cores. The down-core patterns are consistent at both sites. However, at Site 4 the values decrease more gradually to a minimum at $35 \mathrm{~cm}$, while at Site 9 they drop sharply below $50 \mathrm{~cm}$. Mean values for DO and ORP for core 4 are $2.65 \mathrm{mg} / 1$ and $-171 \mathrm{mV}$, respectively, for the top $30 \mathrm{~cm}$ of the core, while from this depth to the bottom, mean values are $0.80 \mathrm{mg} / 1$ and $-291 \mathrm{mV}$. Values for the top 40 $\mathrm{cm}$ of core 9 are $3.37 \mathrm{mg} / 1$ for DO and $-146 \mathrm{mV}$ for ORP, while from $40 \mathrm{~cm}$ to the bottom they are $0.72 \mathrm{mg} / 1$ and $-272 \mathrm{mV}$, respectively. Dissolved pore water iron contents for cores 4 and 9 are shown in Figure $17 \mathrm{c}$. Values are fairly constant along the cores (with some spikes in the upper part of core 9), with mean values of $4.6 \mu \mathrm{mol} / 1$ for core 4 and $8.0 \mu \mathrm{mol} / 1$ for core 9 .

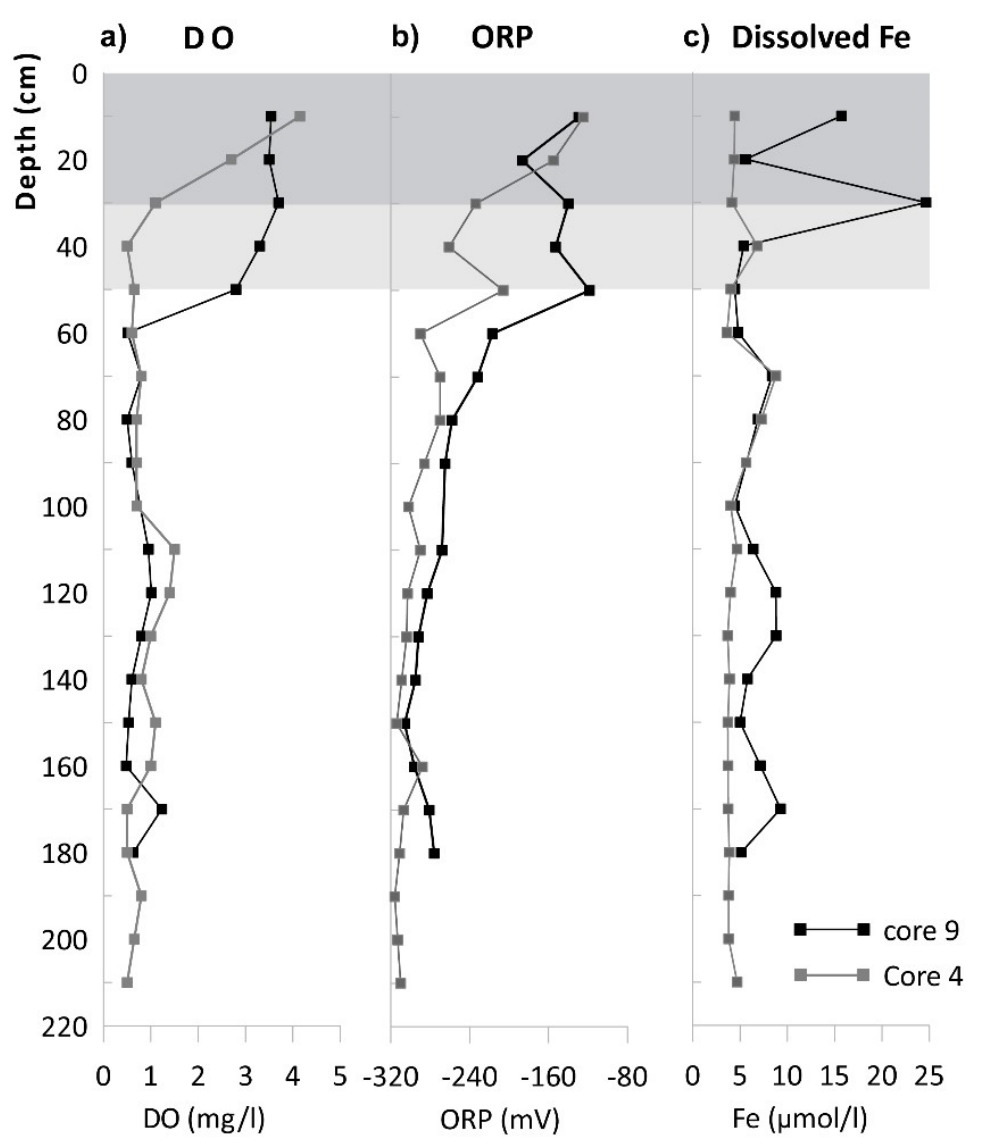

Figure 17 Dissolved oxygen (DO), (b) oxi-reduction potential (ORP), (c) dissolved iron from pore water extracted from core 4 and core 9 . The dark grey and light grey shaded areas indicate the parts enriched in magnetotactic bacteria in core 4 and core 9 , respectively

3.4.6 Mineralogy, grain size, and physical properties

XRD patterns indicate the presence of 4 principal mineral phases: quartz, Na-feldspar, kaolinite, and illite (Figure 6b). The proportion of these phases does not vary significantly down-core, with mean concentrations of $45 \%, 23 \%$, $12 \%$, and $20 \%$, respectively. This constant

mineralogical composition suggests that sediment provenance did not change throughout the studied time 
interval. Grain size analyses indicate that the sediment is composed predominantly of clay and silt, with a small fraction of sand (Figure 18a-c). Down-core variations are minimal, with a few intervals with slightly greater sand contents, at $\sim 40$ and $\sim 70 \mathrm{~cm}$ bsf.

MSCL measurements are shown in Figure 18d-g. The mean value for P-wave velocity is 1437 $\mathrm{m} / \mathrm{s}$, for most of the core. In the first $25 \mathrm{~cm}$ of sediment the mean P-wave velocity is slightly lower, at $1262 \mathrm{~m} / \mathrm{s}$, probably due to higher water content in the sediment. The values are in some parts lower that the speed of sound in water $(\sim 1530 \mathrm{~m} / \mathrm{s}$, Weast, 1969$)$, probably due to high water content and high porosity of the medium. Density values follow the same pattern, with values that increase from about $1.4 \mathrm{~g} / \mathrm{cc}$ to a steady value of $1.99 \mathrm{~g} / \mathrm{cc}$. Long-core susceptivity values are almost stable at about 3.4 (adimensional). Values decrease towards the tips of the core, for about $20 \mathrm{~cm}$, due to the edge effect of the measurement. Natural gamma ray have low countings per second, with mean value of $64.8 \mathrm{cps}$, with slightly higher counts (68) in the top $5 \mathrm{~cm}$, and a maximum of 71 at $2.3 \mathrm{mbsf}$. 

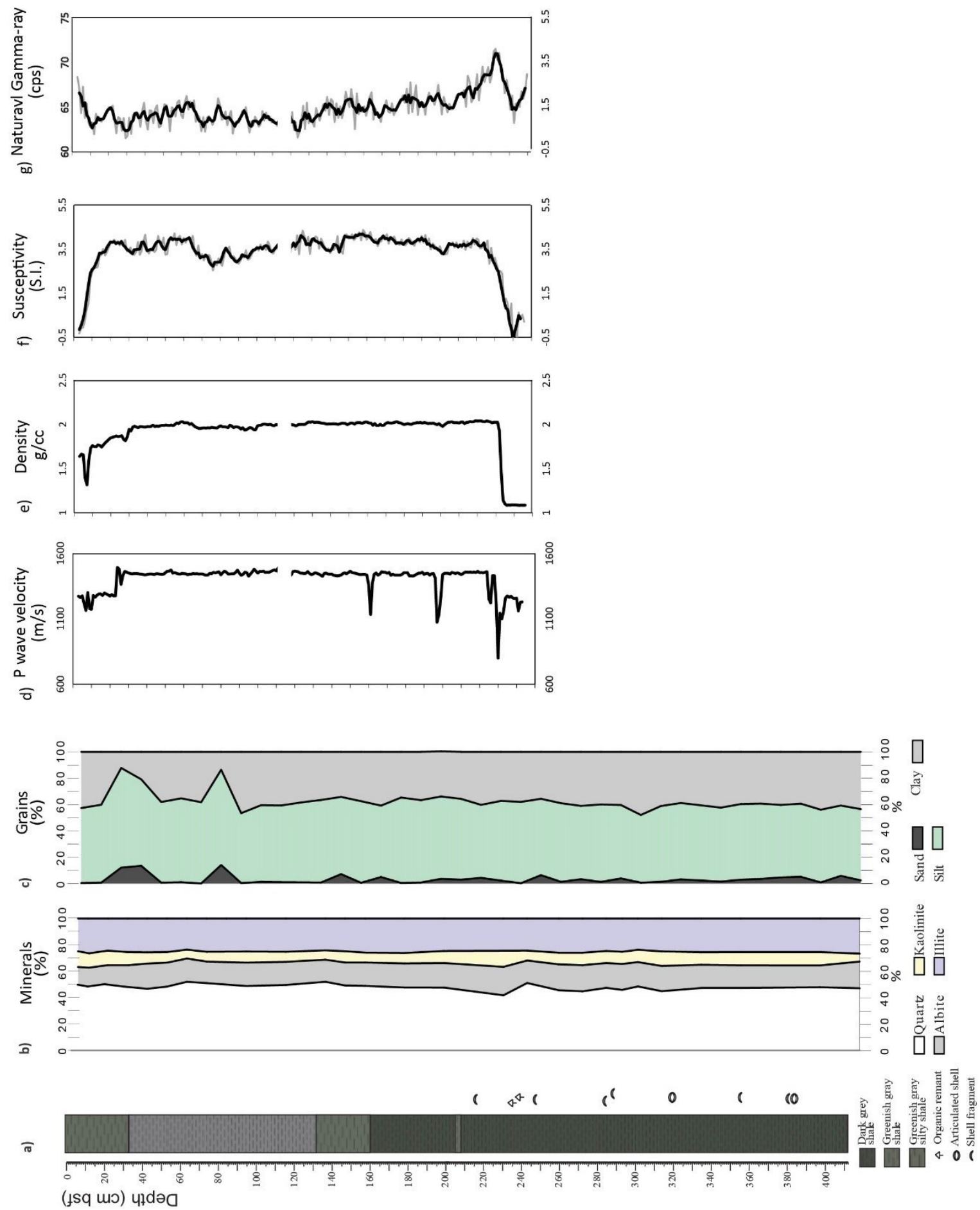

Figure 18 lithological and physical properties of Core 9. (a) Lithological log, (b) relative abundance of the four main mineral constituents, and (c) grain size distribution down the core, expressed as a percentage of the total sediment; (d-g) Multisensor core log for core 9, the dotted gray line represents the point where the core was cut into 2 parts in order to fit in the equipment, grey lines in the susceptibility and natural gamma ray represent the raw data, the black line in these graphs is a running average (step 3). 


\subsection{Discussion}

Environmental magnetic variations indicate that the uppermost $10-40 \mathrm{~cm}$ of sediment from Mamanguá Ría is rich in biogenic magnetite. This magnetite would have been produced in situ by magnetotactic bacteria, and is mixed with a small percentage of detrital magnetite and hematite sourced from weathering of local granites. Magnetite and hematite can also be produced during pedogenesis, and soil particles will have been transported into the basin and contributing to sedimentary magnetic properties. High concentrations of oxygen in the sediments are expected to cause oxidation of magnetite crystals. Nevertheless, biogenic magnetite can be stable in oxidizing environments such as the uppermost Mamanguá Ría sediment column because magnetosome crystals in living magnetotactic bacteria are encapsulated by a protein membrane (Bazylinski et al., 1993).

In order to understand the relationship between the characteristics of biogenic magnetite and the environment where it forms, we studied different variables that could have affected its formation and preservation. Lithology (assessed through mineralogy, granulometry, density, and natural gamma ray analyses) and sedimentation rate were shown to be constant along the core, therefore, the variation of concentration and characteristics of biogenic magnetite cannot depend on them.

Dissolved iron and oxygen contents in the water column are known limiting factors for magnetite biosynthesis (Liu et al., 2010). The steady sedimentation rate, the relatively constant detrital magnetic mineral abundance, and the homogeneous lithology and grain size, indicate that the sediment supply did not change significantly throughout deposition. Therefore, the influx of key nutrients, such as $\mathrm{Fe}$, is likely to have been relatively constant throughout the studied interval. Consequently, the absence of biogenic magnetite at depths below 10,30, and $35 \mathrm{~cm}$ (cores 1, 4, and 9, respectively) is best explained by reduced oxygen concentrations. The dissolution of magnetite should lead to an increase of dissolved Fe in the pore water, but of such phenomenon was not observed in our data. The lack of increase in dissolved Fe in the water column with depth, could be due to reduction of electron acceptor s such as $\mathrm{O}_{2}, \mathrm{NO}_{3}$, $\mathrm{Mn}(\mathrm{IV}), \mathrm{Fe}\left(\mathrm{III}\right.$ ), and $\mathrm{SO}_{4}$ (Zhang et al., 1996). Fe from the dissolution of biogenic magnetite could by promptly sequestrated by sulfate reduction bacteria present in the sediment, that are known to precipitate various metals like $\mathrm{Fe}, \mathrm{Pb}, \mathrm{Zn}, \mathrm{Cu}$, and $\mathrm{Cd}$ as insoluble phases (Morse 
and Luther, 1999). The sulfide used by these bacteria likely comes from the degradation of organic matter (Charriau et al., 2011).

The disappearance of biogenic magnetite with depth, together with an almost constant amount of detrital magnetic minerals suggest that the terrestrial detrital input is constant in terms of quantity of transported material through deposition of the studied interval, which is consistent with the constant sedimentation rate indicated by the age model.

The diagram for the stability of Fe minerals as a function of $\mathrm{pH}$ and ORP (Figure 19, Pourbaix and Zubov, 1963), shows that samples of the topmost part of the cores fall in the area of stability of Fe as hydroxide, in this case goethite. It is important to stress the fact that biogenic magnetite in living bacteria is protected by phospholipidic membranes, therefore does not need to be in chemical equilibrium with the external environment. Samples in the diagram form a trajectory, as the depth increases, that tends toward the area of stability of $\mathrm{Fe}^{+2}$ in solution. The oxygen gradient measured in the pore water profiles reflects the decomposition of organic matter, which consumes most of the oxygen within the uppermost tens of centimeters of sediment. This has a direct effect on biogenic magnetite preservation. A negative spike in the S-ratio, which is interpreted to reflect a rapid relative increase in higher coercivity magnetic minerals contribution (maghemite or hematite), occurs at the transition from oxic to ferruginous conditions, where the oxygen concentration decreases so rapidly that magnetotactic bacteria cannot survive.

The rapid decrease of D.O. and ORP at $\sim 40 \mathrm{~cm}$ depth (from $3 \mathrm{mg} / 1$ to $0.5 \mathrm{mg} / 1$ for D.O. and from $-160 \mathrm{mV}$ to $-260 \mathrm{mV}$ for ORP) suggests that the oxidizing local redox environment in the upper part of the sediment column is responsible for the rapid shift from magnetite to maghemite. As MTB die, the phospholipid membrane that encases crystals in live bacteria degrades and exposes the crystals to the external environment. MTB in Mamanguá Ría appear to thrive where D.O. values are higher than $2.5 \mathrm{mg} / \mathrm{L}$ and die at lower levels. Regardless, D.O. concentrations below $\sim 40 \mathrm{~cm}$ depth may still be high enough for magnetite to undergo partial oxidation. 


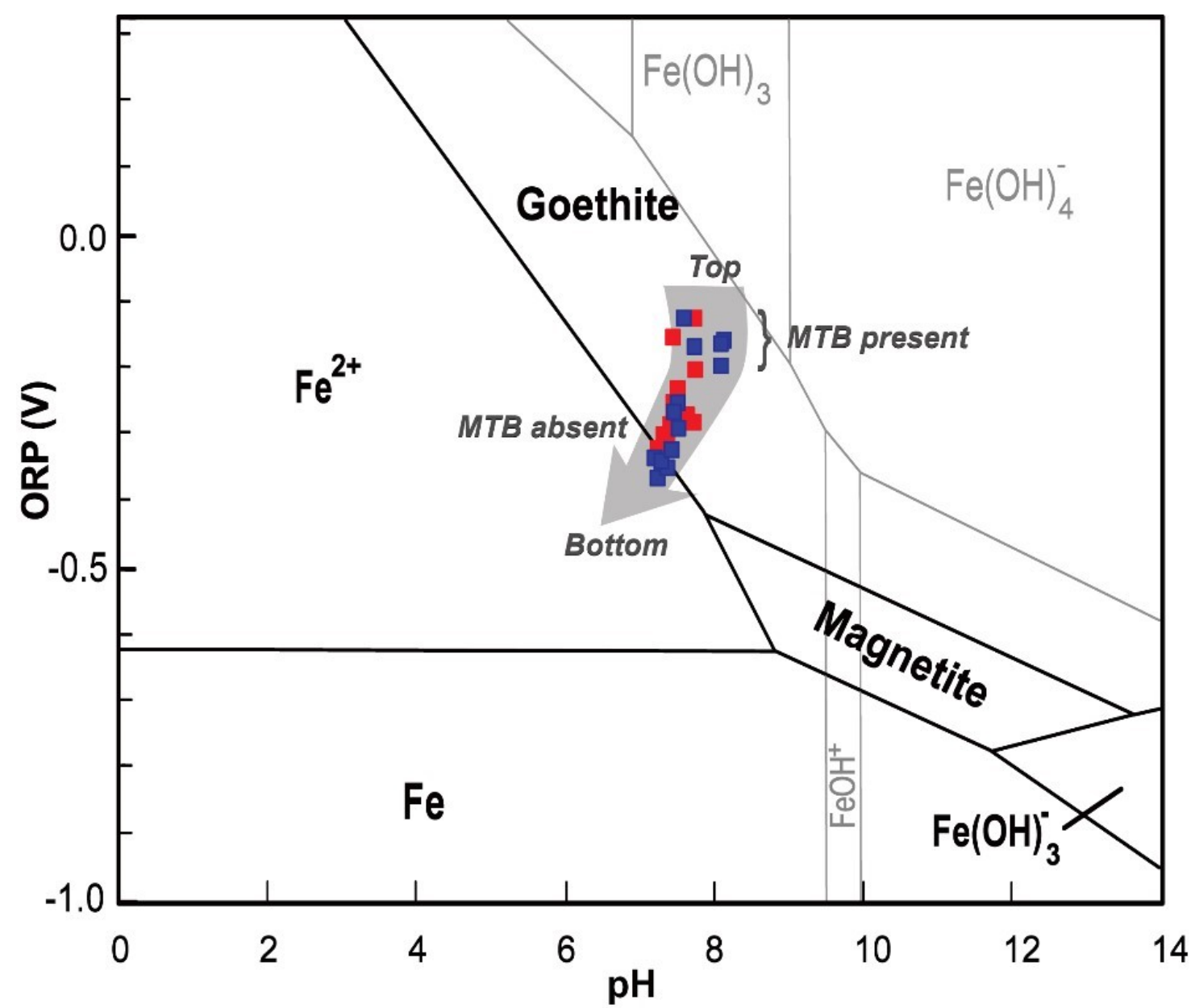

Figure $19 \mathrm{pH}$ versus ORP diagram for Fe in acqueous solution (Poubaix and de Zubov, 1963) of core 9 (blue squares) and core 4 (red squares). The light gray arrow indicates the average direction, from the top of the cores to the bottom, of the $\mathrm{pH}$ vs. ORP values

Yamazaki and Kawahata (1998) demonstrated that magnetite magnetofossil morphology depends on organic carbon flux to the seafloor, with more elongated morphologies occurring in less oxic environments and vice versa. Egli (2004a, 2004b, 2004c) demonstrated that, in lake sediments, BS and $\mathrm{BH}$ magnetite behave differently in environments with low oxygen concentrations, where $\mathrm{BH}$ is more stable than $\mathrm{BS}$. The difference between $\mathrm{BS}$ and $\mathrm{BH}$ lies in the shape of the crystals: where the BS component is dominated by equant octahedra and the $\mathrm{BH}$ component is dominated by elongated parallelepipeds. More widespread evidence from marine sediments now links BS and BH magnetite to variable particle elongation with different species of MTB thriving in different oxygen concentrations (e.g., Yamazaki, 2012; Yamazaki and Shimono, 2013; Chang et al., 2013, 2018; Usui et al., 2017). 
Depth variations of $\mathrm{BS}$ and $\mathrm{BH}$ magnetite in sediments of Mamanguá Ría provide direct insights into the diagenetic fate of these magnetite types from a pore-water based redox zonation in a modern depositional environment. The BS magnetite component is dominant down to $30 \mathrm{~cm}$ below seafloor (bsf), and then diminishes rapidly before disappearing at $36 \mathrm{~cm}$ bsf. The concentration of $\mathrm{BH}$ magnetite, as expected, starts to increase at $29 \mathrm{~cm} \mathrm{bsf}$ before reaching a maximum at $33 \mathrm{~cm}$ and then disappearing $3 \mathrm{~cm}$ deeper that the $\mathrm{BS}$ component at 39 cm bsf. New coercivity components appear in the IRM acquisition curves as soon as the BS and $\mathrm{BH}$ components disappear (Figure 3). These new components have almost the same mean coercivity values as the $\mathrm{BS}$ and $\mathrm{BH}$ components, but with larger dispersion, which indicates that the biogenic magnetite has undergone alteration or dissolution. This behavior allows us to constrain the position of the SMT to $36-39 \mathrm{~cm}$ bsf.

An increasingly oxidized state and octahedral structure of magnetite with depth in the studied sediments is evident from the direct probing provided by XANES data. In contrast, FORC diagrams for the sediment samples are virtually identical. Thus, even if magnetite undergoes structural alteration with depth in the sediment column, with surficial maghemite formation, this transition does not produce a clear FORC signal (consistent with the findings of Chang et al. (2013)). These results indicate how XANES data are more sensitive to subtle changes in crystal structure and chemistry than standard magnetic analyses. Assuming that the same MTB species is present in the sediment, differences in magnetite structure and oxidation state can be used to understand different environments in which these bacteria live.

\subsection{Conclusions}

XANES spectra for cultivated $M$. australis, compared with those for magnetotactic bacteria from recent sediment, and magnetic property analyses, indicate that the characteristics of biogenic magnetite crystals depend not only on the MTB species, but also on the postdepositional environment in which they live. On the one hand, magnetite magnetofossils are expected to dissolve and not survive burial under reducing sulfidic conditions (e.g. Roberts, 2015). Magnetofossil preservation has been documented in sediments with a long, oxic postdepositional history (Yamazaki and Shimono, 2013). The results presented here indicate that magnetofossil preservation with depth cannot be assumed when free molecular oxygen can penetrate from the surface into the sediment to oxidize biogenic magnetite. The length of 
time over which magnetofossils can be preserved will depend on the duration over which molecular oxygen can continue to penetrate into the sediment to oxidize magnetofossils. In Mamanguá Ría, magnetofossils have been subjected to progressive surficial oxidation during early burial, but consumption of oxygen by microbial respiration processes at sediment depths of only a few tens of centimeters suggests that oxidation will only occur over a finite and relatively short period of time. Our results demonstrate that use of XANES and magnetic parameters as fingerprints for recognizing mineralogical and magnetic changes in biogenic magnetite are valuable for studying the characteristics of post-depositional alteration of bacterial magnetite in sedimentary environments.

We demonstrate a correlation between environmental chemical conditions and magnetic minerals in surface sediments from Mamanguá Ría, Brazil. Sediment supply did not change significantly throughout the studied short sediment cores, so that sediment composition and relative nutrient abundances are likely to have been almost constant. Sedimentary oxygen content and redox potential, which were measured for pore waters from the studied sediments, therefore, provide the main factors that control the presence or absence of living magnetiteproducing magnetotactic bacteria and magnetite magnetofossil preservation. Biogenic magnetite is present only where the redox potential and dissolved oxygen concentrations are high enough to allow magnetotactic bacteria to live. The abrupt transition between relatively well-oxygenated and oxygen-depleted sediment is marked by the death of magnetotactic bacteria and by rapid magnetosome dissolution. In the microaerobic surface environment, magnetotactic bacteria that produce both the biogenic soft and hard components of Egli (2004a, 2004b, 2004c) are present. With increasing depth over a narrow stratigraphic interval, the biogenic soft component is removed preferentially by reductive dissolution and only the hard component remains. This confirms that the biogenic hard component is more resistant to diagenetic dissolution than the biogenic soft component. At the sulfate-methane transition, the remaining biogenic hard component dissolves and no biogenic magnetite is detected below this transition. At this transition, magnetite dissolution liberates dissolved $\mathrm{Fe}^{2+}$ that then becomes bioavailable for use by other chemosynthetic organisms or for reaction to form inorganic phases such as sedimentary pyrite. Overall, our results provide an important direct constraint that validates interpretations of magnetosome morphology and coercivity in terms of sediment oxygenation. 


\section{Chapter 4. Effects of the closure of the Neo-Tethys on currents from the Indian Ocean to the Atlantic Ocean: an example from a newly descripted section from central Turkey (Elazı ğ Province)}

\subsection{Introduction}

The Neotethys Ocean formed the connection between the Indian Ocean and the equatorial Atlantic Ocean, separating Africa and Eurasia until its closure (Aitchison et al., 2007). This gateway permitted the circulation of waters between the two oceans, as the Subtropical Eocene Neotethys Current (STENT; Jovane et al., 2009), in a paleoceanographic and paleogeographic scenario very different from the present. Several outcrops from the Neotethys (Jovane et al., 2007, 2009, 2010, 2013; Savian et al., 2014, 2016; Cotton et al., 2016) and marine cores from the Indian Ocean (i.e., Savian et al., 2013) have been studied, and they represent records of the paleoclimatic and paleoceanographic conditions in this region during the Paleogene. However, no record of comparable resolution has been obtained so far from the Turkey region. Here, we present a detailed and integrated magnetobiostratigraphic record of a new middle Eocene marine sedimentary section from the Elazığ Basin, located near the town of Baskil, eastern Turkey. The section was selected after a preliminary survey in the area in 2005, which focused on large foraminiferal biostratigraphy (Özcan et al., 2006). Despite the complex tectonic history of the region, which is characterized by continental collision between multiple microplates and intrabasinal deformation (Şengör and Yılmaz, 1981), this area in particular was not affected by tectonic deformation, erosional events, and depositional hiatuses. Its wellpreserved facies and paleontological record, the stratigraphic continuity, and the high sedimentation rate make this section ideal for an integrated multistratigraphic study, which allows for calibrating the major paleoclimatic, paleoenvironmental, and biotic events to the current geochronological time scale. Additionally, considering its paleogeographic position, this area could be particularly sensitive to the paleoceanographic and paleoclimatic changes related the closure of the Neotethys during the Eocene. The magnetic signal, preservation of fossils, and high sedimentation rate will allow the recognition of climatic events, like the Middle Eocene climatic optimum (Bohaty and Zachos, 2003; Bohaty et al., 2009; Sluijs et al., 2013), which represents one of the most important warming events of that period, when mean sea-surface temperatures increased and then decreased by $4-6{ }^{\circ} \mathrm{C}$ in less than $1 \mathrm{~m} . \mathrm{y}$. Thus, this work provides the stratigraphical basis for constraining the reconstruction of the causes and 
consequences of paleoclimatic events and paleoceanographic changes during the middle Eocene.

\subsection{Geological setting}

The studied section, hereafter named the Baskil section, outcrops $19.8 \mathrm{~km} \mathrm{NWW}$ of the town of Baskil, in the Elazı ğ Province, in eastern Turkey (located at $38^{\circ} 36^{\prime} 30.34^{\prime \prime} \mathrm{N}, 38^{\circ} 36^{\prime} 03.46^{\prime \prime} \mathrm{E}$; Figure 20). The main succession consists of massive marl locally intercalated with turbiditic and calcarenitic beds (Figure 21). Most of these calcarenites contain accumulations of large benthic foraminifera, and this section represents a key locality in Turkey for recording the large benthic foraminifera events of the Bartonian (Özcan et al., 2006). Such calcarenitic beds, with thickness ranging from a few centimeters to several decimeters, occur at various intervals throughout the entire section. In the central part of the section, from 185 to $200 \mathrm{msl}$ (meters stratigraphic level from the base of the section), six thick strata (with thickness up to more than $1 \mathrm{~m}$ ) have been observed, with typical turbiditic facies. Given the stratigraphic proximity and the similar facies association, these six layers (here named Sister 1-6) are thought to have a common origin, instead of representing isolated events like those responsible for the deposition of the other calcarenites. The strata in the section show an almost constant gentle dip $\left(13^{\circ}\right)$ toward NNW $\left(313^{\circ}\right)$. The section encompasses a limited part of the Kırkgeçit Formation, which is an extensive and thick siliciclastic-carbonate unit of Lutetian to Rupelian age that lies unconformably on top of a metamorphic and magmatic basement (Aksoy et al., 2005). The section is in the same area as the Keçili section described by Özcan et al. (2006), and it covers almost the same portion of the sequence, except for its lower part.

The Elazı $\breve{g}$ Basin is one the several basins in Turkey that developed during the closure of the western Neotethys. Permian to Quaternary sedimentary rocks outcrop within this basin, with a very well-studied stratigraphic framework (Bingöl, 1984; Turan, 1984; Sungurlu et al., 1985; Tatar, 1987; Akpınar, 1988; Özkul, 1988; Türkmen, 1991; Aksoy, 1993; İnceöz, 1994; Turan et al., 1995; Aksoy et al., 1996; Özkul and Kerey, 1996; Turan and Türkmen, 1996; Türkmen et al., 1999, 2001). The basement of the basin is formed by the Upper Cretaceous Keban metamorphic complex and the Upper Cretaceous Elazı $\breve{g}$ complex, with the former consisting of marbles, calc-phyllites, calc-schist, and metaconglomerates in amphibolite-greenschist 
facies (Turan and Bingöl, 1991), and the latter consisting of basalts, andesites, pillow lavas, dacites, aplites, dolerites, and plutonic rocks (Akgül, 1993; Bingöl and Beyarslan, 1996). The Paleogene sequence consists of Lower Paleocene conglomerates and sandstones related to mass flows passing into red sandstones and mudstones (Heward, 1978). Upward, an Upper Paleocene-Lower Eocene unit is composed of limestones mainly formed by algae and benthic foraminifera, with a high fraction of micritic matrix (Aktaş and Robertson, 1984). Overall, the middle Eocene-lower Miocene deposits are considered to be the products of a shallow- to deep-marine shelf environment and were deposited in a back-arc basin developed on continental crust (Özkul, 1988).

The middle and upper Eocene deposits are represented by shallow- to deep-marine sediments, characterized by carbonate and terrigenous shelf, continental slope, slope apron, and basinplain environments. These deposits accumulated during a period of rapid subsidence related to block faulting within a back-arc setting (e.g., Aktaş and Robertson, 1984). Terrigenous shelf deposits outcrop with an ENE-WSW trend and are mainly made up of trough and hummocky crossbedded calcarenites, in some places alternating with sandstone and mudstone beds. Calcarenites generally contain reworked nummulites (Aksoy et al., 2005). Basin-plain deposits, which include hemipelagic mudstone with sandstone interbeds, are found in the southern portion of the basin (Özkul and Kerey, 1996). Paleocurrent analyses on sole marks in the sediment indicate mass flows coming from the NE to SW, through channels parallel to the slope, and the lithofacies distribution indicates that the sea deepened toward the south (Özkul, 1988). Oligocene-Miocene deposits are represented by shallow-marine carbonates containing large benthic foraminifera, coralline algae, bryozoans, and corals deposited as massive banks on topographic highs on the shelf. Bedded limestones were formed by the reworking of bioclastic material in the shoal and protected areas within the shelf, while shelf-edge carbonates formed westward and are now exposed on the hills west of Baskil. 


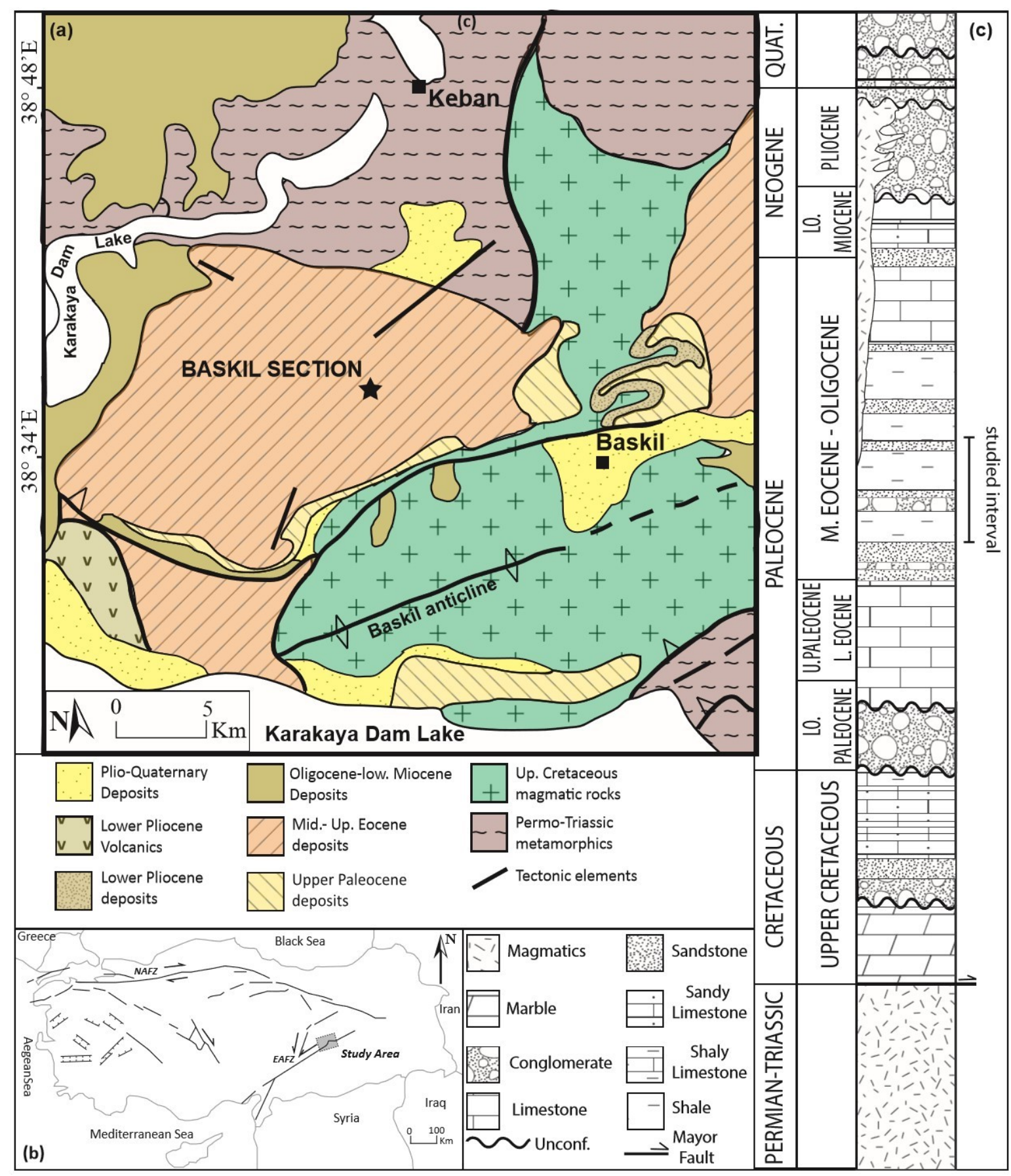

Figure 20 Schematic geological map of the Elazığ-Baskil area; black star shows the position of the studied section. (B) Tectonic sketch of Turkey, with the gray box indicating the position of the Elazığ-Baskil area, modified after Aksoy et al. (2005). (C) Lithostratigraphic column of the sedimentary succession in the Elazığ Basin, modified after Calgar (2009), with studied interval marked (fo._-Formation; NAFT — North Anatolian Fault Zone; EAFT_ East Anatolian Fault Zone).

The Elazığ Basin developed in a convergent margin and was characterized by a peculiar tectono-sedimentary evolution related to the interplay between the accommodation space gained in a thrust-top setting and related pulses of localized extensional tectonics (Aksoy et al., 
2005; Robertson et al., 2007; Şengör et al., 2008). Models highlight that from the late Paleocene, marine deposition was mainly controlled by syndepositional normal faulting, in contrast with the general tectonic setting, which was mainly compressional. According to Robertson et al. (2007), normal faulting can be considered as the local effect of crustal deformation that took place during thrusting toward the Arabian foreland. The activity of synsedimentary normal faults provided accommodation space for a broad area (i.e., basin), $w$ here a thick succession, exceeding $1000 \mathrm{~m}$, was deposited in a marine environment.

\subsection{Methods}

The studied Baskil section interval spans from 0 to $357 \mathrm{msl}$. Preliminary sampling took place in 2010 to construct a pilot low-resolution stratigraphic framework. The Baskil section was then sampled in 2012 and 2015 at higher resolution. Hand samples were collected from the outcrop, with mean spacing of $1.5 \mathrm{~m}$. In the parts of the section where we expected inversions, at least one sample every meter was collected. In total, 233 oriented samples were collected in the field for paleomagnetic studies after removal of surface-altered rocks. 

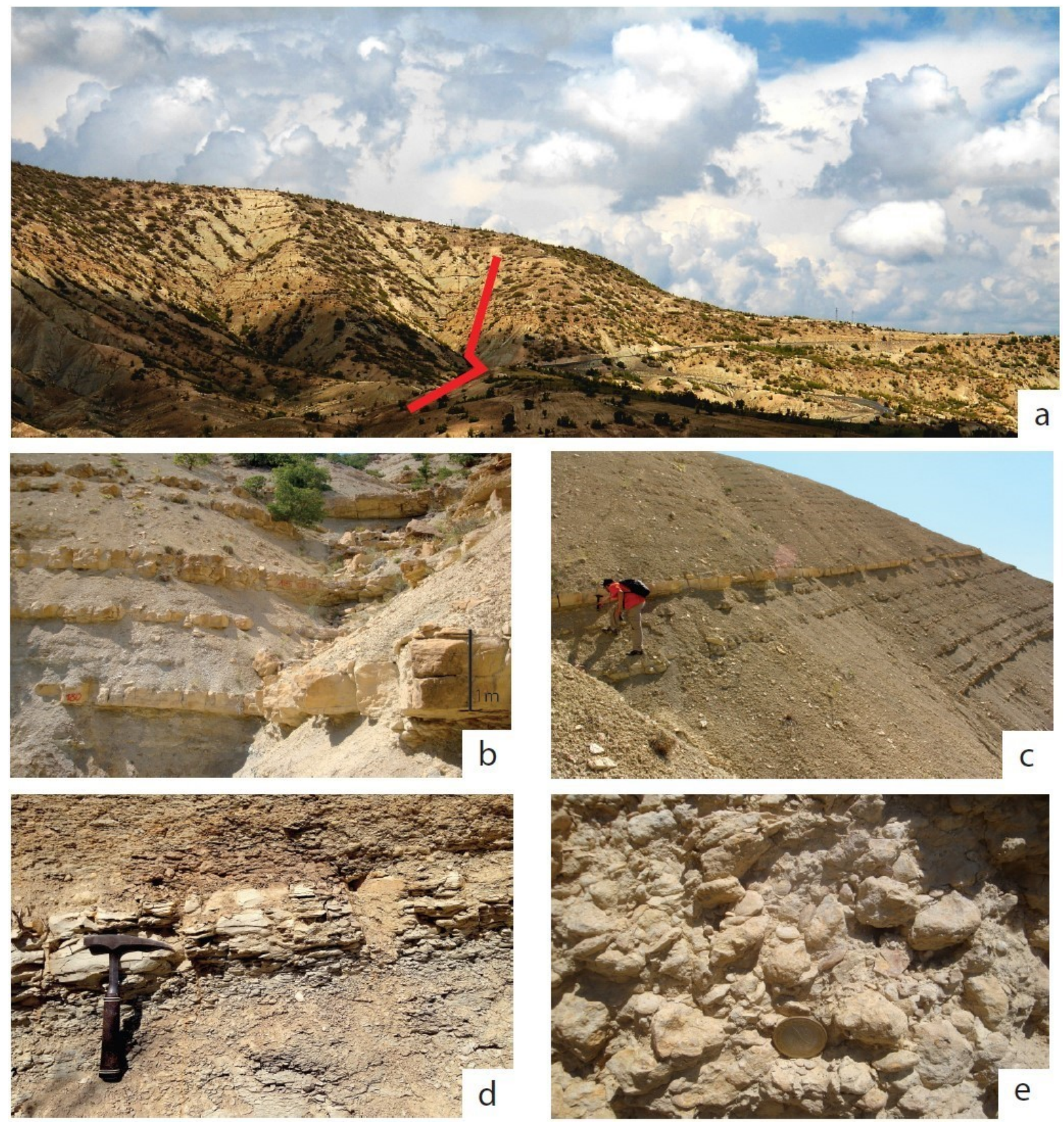

Figure 21 (A) Panoramic view of the studied section, with the sampling location highlighted with a red line; (B) view of the turbiditic beds (Sisters 1-6); (C) several calcarenitic beds intercalated with mudstone (thickest is at $106 \mathrm{msl}$, where msl - meters stratigraphic level from the base of the section; (D) detail of a calcareous marl below Sister 1; (E) detail of a calcarenitic bed with nummulites at the base of Sister 5 bed.

\subsubsection{Anisotropy of Magnetic Susceptibility}

The magnetic fabric in sedimentary rocks can be acquired during and after the deposition of the sediments, as a result of currents, bioturbation, compaction, and tectonic disturbances (Rees, 1961). In order to define the degree of tectonic influence on the depositional and 
postdepositional history of the section, analyses of the anisotropy of the magnetic susceptibility (AMS) were carried out on 40 selected samples. AMS was measured using an AGICO Kappabridge KLY-4 and analyzed using AGICO Anisoft software. The AMS represents a second-rank tensor with six independent matrix elements that characterize an ellipsoid. Following the analysis, several parameters were calculated from susceptibility axes K1, K2 , and $\mathrm{K} 3$, which are, respectively, the maximum, intermediate, and minimum axes of the ellipsoid described by the matrixes (Rochette et al., 1992). Parameters included mean susceptibility (Km), foliation (F), lineation (L), shape factor (T), and q-factor (q; Graham and Hamilton, 2004). The two shape parameters, $\mathrm{T}$ and $\mathrm{q}$, are known for the susceptibility ellipsoids, where $\mathrm{T}$ describes the shape of the ellipsoid (from prolate to oblate), while $\mathrm{q}$ is used to distinguish the nature of the fabric development (e.g., depositional or tectonic fabric; Hamilton and Rees, 1970).

\subsubsection{Planktonic Foraminifera}

In total, 116 samples were analyzed for planktonic foraminiferal biostratigraphy. Samples were treated following the cold acetolysis technique of Lirer (2000) by sieving through a $63 \mu \mathrm{m}$ mesh and drying at $50{ }^{\circ} \mathrm{C}$. This technique enabled the extraction of commonly easily identifiable foraminifera even from indurated limestones. This technique offered the possibility of accurate taxonomic determination and detailed analysis of foraminiferal assemblages. The residues were studied with a binocular microscope to characterize assemblages and identify biostratigraphic marker species following the taxonomic criteria of Pearson et al. (2006). The planktonic foraminiferal standard zonation scheme of Wade et al.

(2011) was followed.

\subsubsection{Smaller Benthic Foraminifera}

The same set of samples for planktonic foraminifera was used for benthic foraminiferal analysis. The quantitative study was performed on 29 selected samples. A representative split of the $>125 \mu \mathrm{m}$ fraction was used to pick $\_300$ specimens. Paleobathymetric estimates of the section were evaluated based on the presence of index taxa. Paleodepth assignment was performed following the bathymetric subdivision provided by van Morkhoven and Edwards (1986) and Berggren and Miller (1989): inner neritic (0-30 m), middle neritic (30-100 m), 
outer neritic (100-200 m), upper bathyal (200-600 m), middle bathyal (600-1000 m), lower bathyal (1000-2000 m), upper abyssal (2000-3000 m), and lower abyssal (>3000 m).

\subsubsection{Larger Benthic Foraminifera}

Classification of large benthic foraminifera was made on thin sections or on isolated split specimens, because the identification was based on their internal structures. We followed the morphometric method described in detail by Drooger (1993); i.e., in each sample, the specimens were grouped into populations, the members of which were clearly distinguishable from the specimens of the other populations of the same sample. The zonations were identified according to the schemes of Serra-Kiel et al. (1998) and Less and Özcan (2012).

\subsection{Results}

\subsubsection{Magnetostratigraphy}

Following the principal component analysis, the majority of the samples showed two components: (1) one isolated up to $100-150 \mathrm{mT}$ of AF demagnetization representing a viscous remanent magnetization (VRM), and (2) the second one recognizable up to $80 \mathrm{mT}$, and in a few samples, up to $100 \mathrm{mT}$, interpreted as the ChRM. The magnetization of the samples shows a decrease of up to $70 \%$ of the intensity in the first steps of AF demagnetization, stabilizing and slowly decaying from $20 \mathrm{mT}$ to $100 \mathrm{mT}$ (Figure 22). Out of the original 233 samples, only 165 (70\%) were retained to define the ChRM of the Baskil section (Figure 23). Mean directions were separately calculated for normal and reverse polarity populations, as in Jovane et al. (2008). In total, 93 (57\%) samples had a positive inclination, with a mean inclination of $36.4^{\circ}$, and a95 of $4.7^{\circ}$, while $72(43 \%)$ samples exhibited negative inclination, with a mean inclination of $-38.5^{\circ}$, and a95 of $8.3^{\circ}$. These values indicate that the magnetostratigraphic record passes the reversal test (McFadden and Lowes, 1981). The magnetic polarity record of the studied section can be subdivided into 12 magnetozones, with an alternation of six reverse polarity (R) and six normal polarity intervals $(\mathrm{N})$. The positions along the section of the magnetozones are reported in Table 1. The lower limit of R1 and the upper limit of N6 correspond to the bottom and top of the studied section, respectively (Figure 23). 


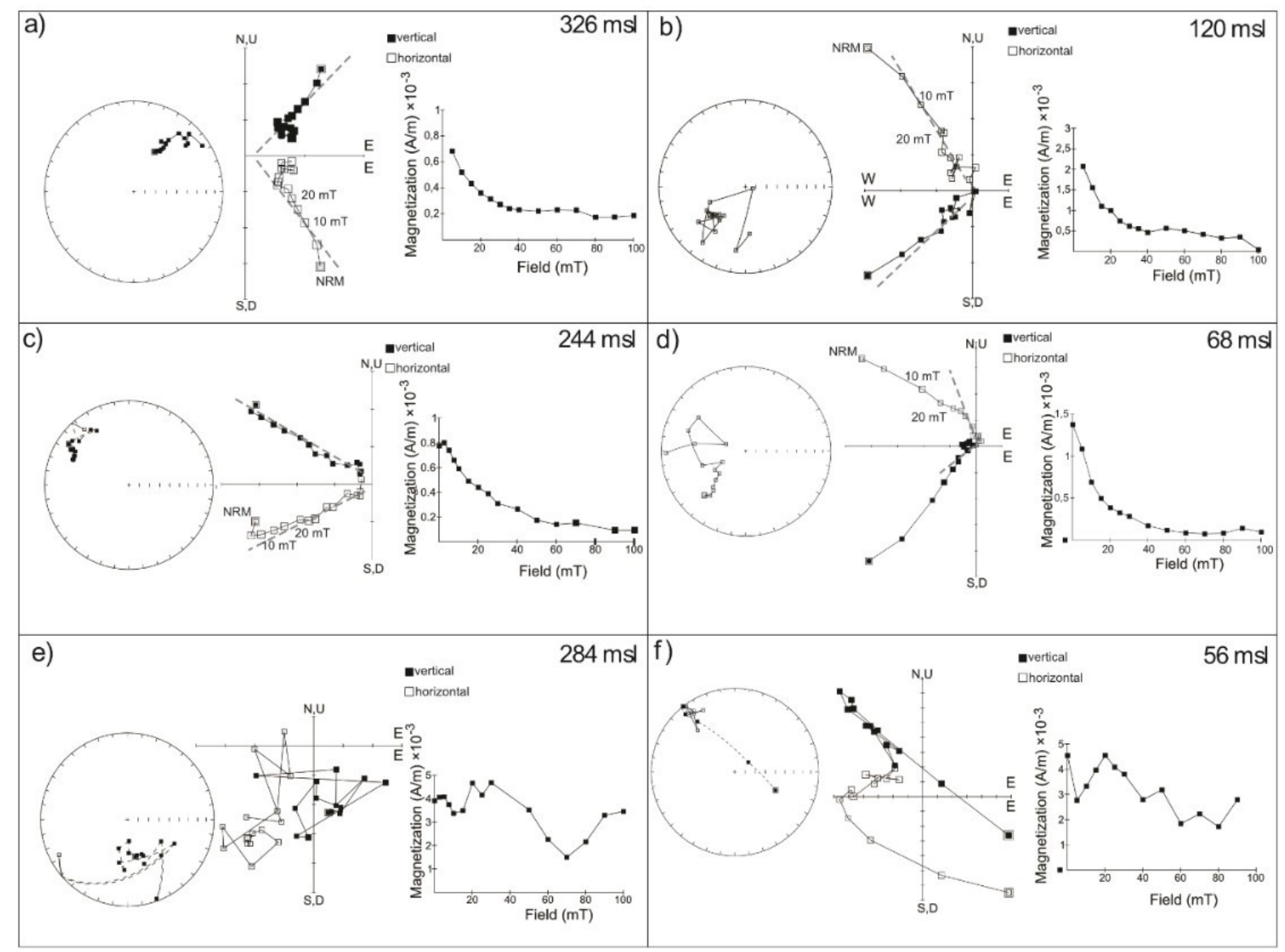

Figure 22 Orthogonal and vector component diagrams and intensity decay plots for alternating field (AF) demagnetization data for six representative samples. Open and filled squares represent projection onto the vertical plane and the horizontal plane, respectively. Dotted line represents the characteristic remanent magnetization (ChRM). (A, C) Examples of reversed polarity ChRM; (B, D) examples of normal polarity ChRM; (E-F) examples of discarded samples due to poor quality of the data. NRM - natural remanent magnetization; mslmeters stratigraphic level from the base of the section. 
a)

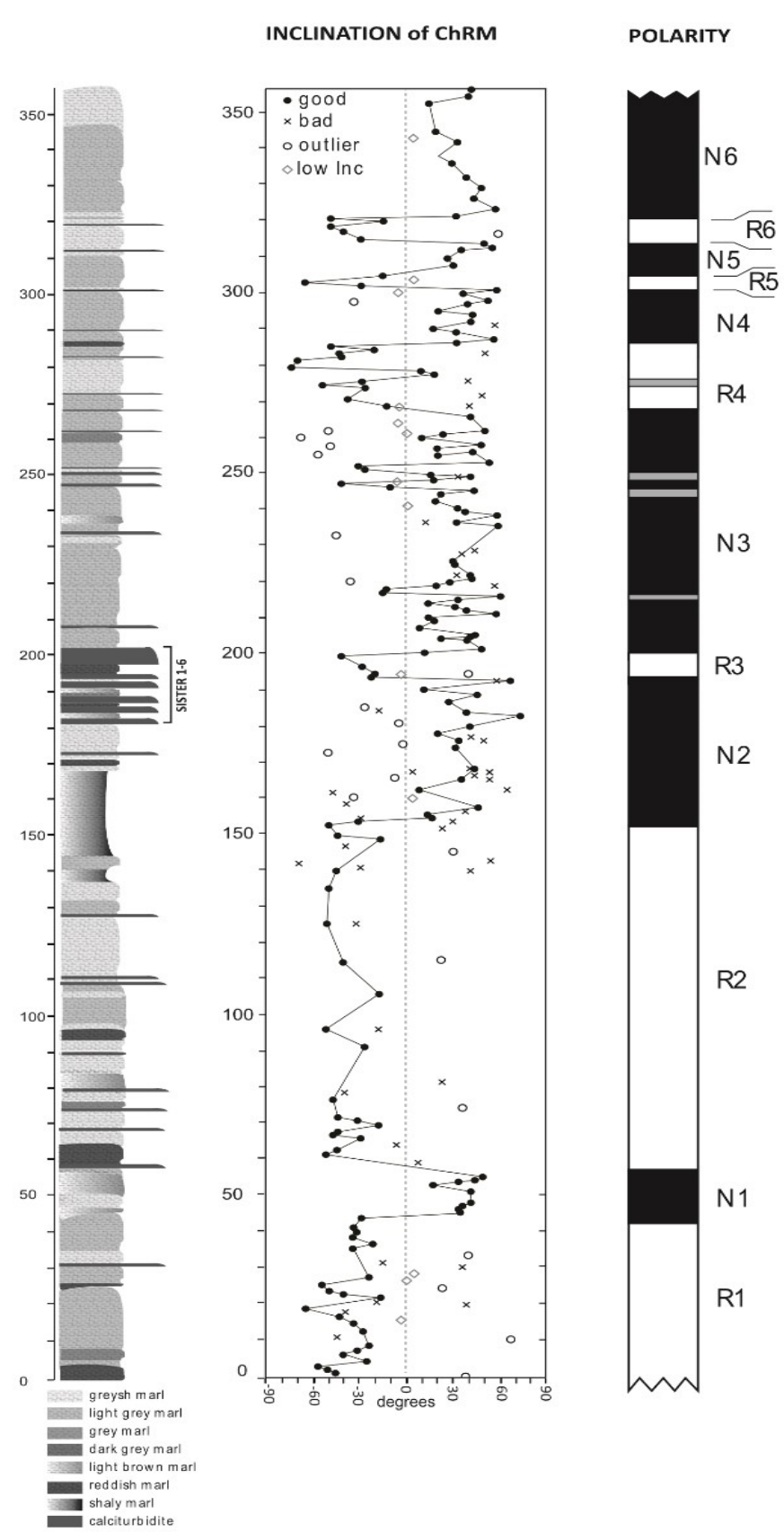

d)

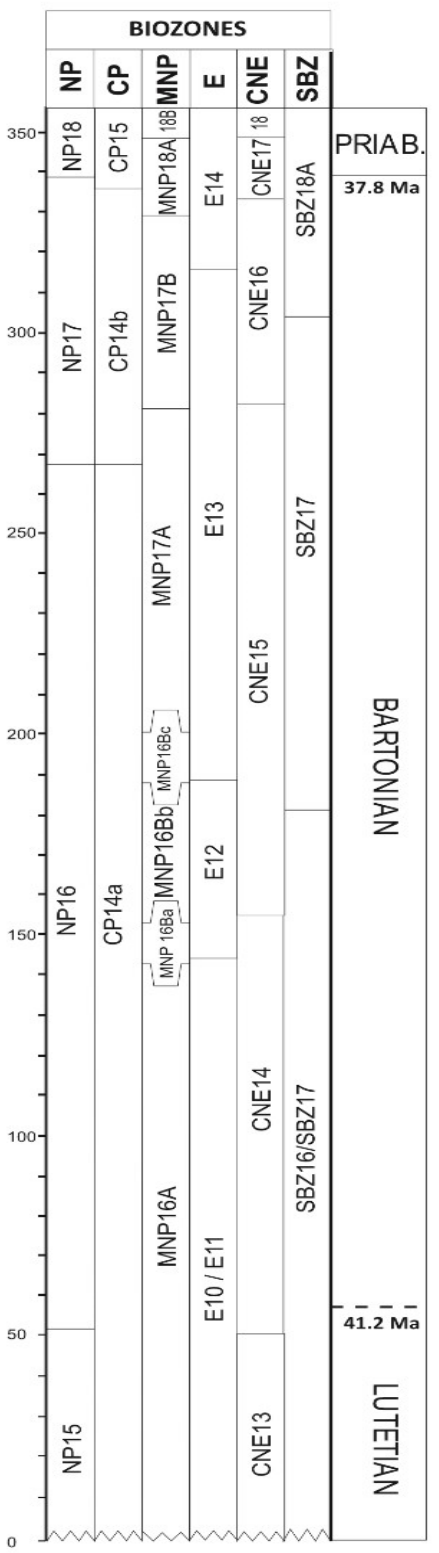

Figure 23(A) Stratigraphic log of the studied section. (B) Curve of the inclination values of the characteristic remanent magnetization (ChRM), with "good," "bad," "outlier," and "low inc" classified as in the text. (C) Magnetozones defined using the values of inclination of the ChRM: black indicates normal polarity, white indicates reversed polarity, and gray indicates ambiguous intervals. (D) Calcareous nannofossil zones and subzones after Martini (1971, listed as NP), Okada and Bukry (1980, listed as CP), Fornaciari et al. (2010, listed as MNP), and Agnini et al. (2011, listed as CNE). Planktonic foraminiferal zones are after Wade et al. (2011, listed as E). Larger benthic foraminiferal zones and subzones are after Serra-Kiel et al. (1998) and Less and Özcan (2012). Chronostratigraphy is after Gradstein et al. (2012). 


\subsubsection{Anisotropy of Magnetic Susceptibility}

AMS measurements were averaged between the different samples to assess the general postdepositional tectonic stress acting on the sediment, as no significant changes with lithology or stratigraphic position were observed. Averaged values for the susceptibility parameters K1 , $\mathrm{K} 2$, and $\mathrm{K} 3$ are: $\mathrm{K} 1=1.016, \mathrm{~K} 2=1.009$, and $\mathrm{K} 3=0.976$, leading to a shape parameter $\mathrm{T}$ of 1.0003, which indicates an almost spherical-shaped ellipsoid (Figure 24). The q factor is equal to 0.191, which indicates a primary depositional fabric (Hamilton and Rees, 1970). K1 is oriented E-W, K2 is clustered around the pole, and K3 is oriented N-S. Mean L (Basley and Buddington, 1960) and F (Stacey et al., 1960) values are 1.006 and 1.033, respectively.

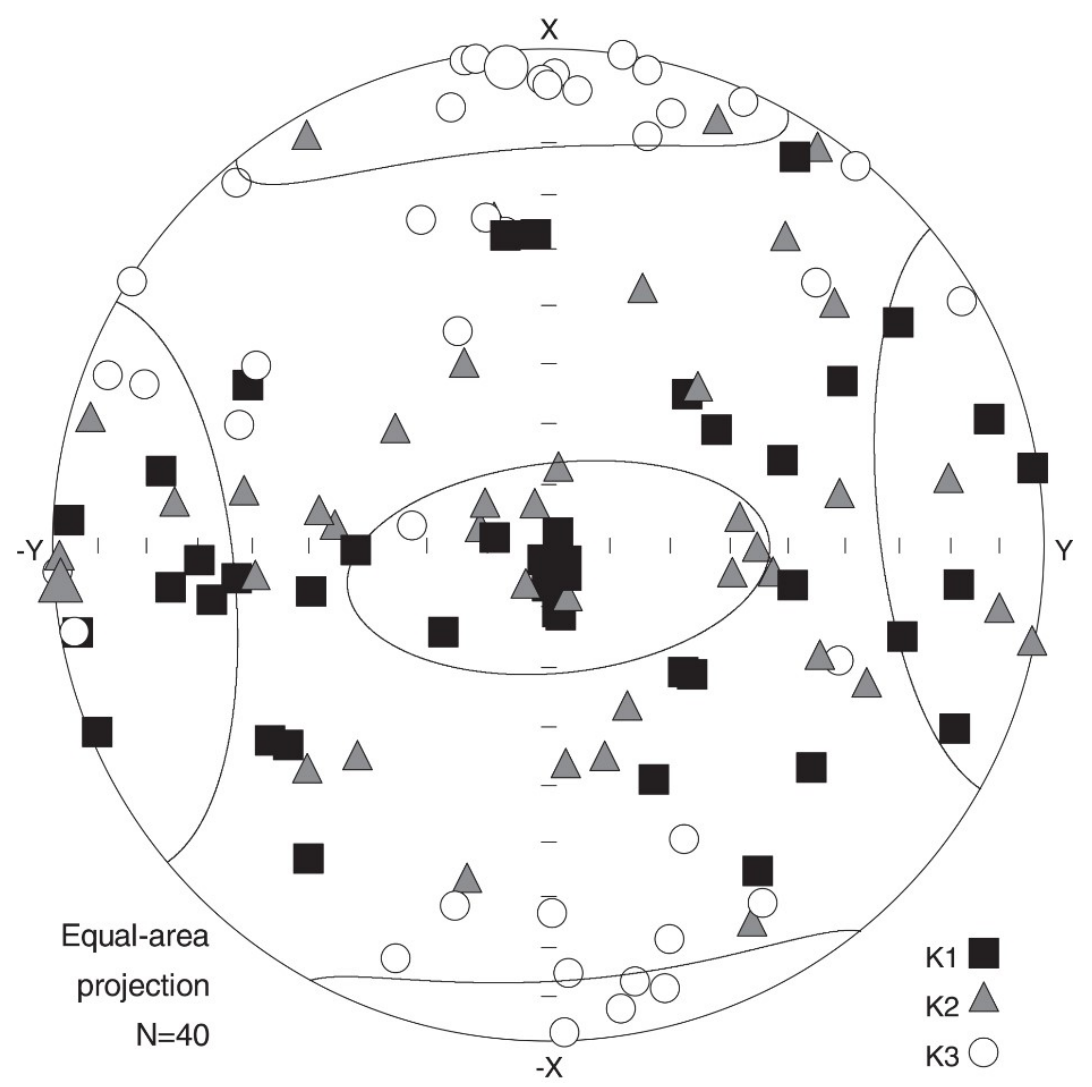

Figure 24 Lower-hemisphere projection of K1, K2, K2 tensor orientations, with mean direction and confidence ellipses.

\subsubsection{Calcareous Nannofossil Biostratigraphy}

The calcareous nannofossils are common to abundant and show good preservation in almost all the samples. The time interval studied would span the middle Eocene Lutetian-Bartonian transition, in which 13 bioevents were identified (Table 4) and delineated as lowest occurrence 
(LO), highest occurrence (HO), lowest common occurrence (LCO, defined as the lowest continuous occurrence $>1 \%$ ), highest common occurrence ( $\mathrm{HCO}$, defined as the highest continuous occurrence $>1 \%$ ), acme beginning ( $\mathrm{AB}$, defined on abundance $>10 \%$ ), and acme ending ( $\mathrm{AE}$, defined on abundance $<10 \%$ ) of species indicative for the construction of the middle Eocene calcareous nannofossil biostratigraphy. The semiquantitative and quantitative analyses proved that some biohorizons are reliable, while others are essentially useless.

The Coccolithaceae are represented by the genera Coccolithus, Chiasmolithus, and Ericsonia. The genus Coccolithus contains Coccolithus pelagicus and very rare, not separately counted Coccolithus eopelagicus, which were recorded with percentages between $>1 \%$ and $<30 \%$. The genus Chiasmolithus was detected in low numbers in all the investigated samples.

The recognized species are Chiasmolithus grandis, Chiasmolithus oamaruensis, Chiasmolithus solitus, and Chiasmolithus titus. Chiasmolithus grandis occurred from the base of the section to $336.6 \mathrm{msl}$. Chiasmolithus oamaruensisoccurred from $342.0 \mathrm{msl}$ to the top, Ch. solitus had its LO at $269 \mathrm{msl}$, while Ch. tituscharacterized the first $60 \mathrm{~m}$ of the section. Chiasmolithus $\mathrm{cf}$. gigas was present at $11 \mathrm{msl}$ and $45.5 \mathrm{msl}$.

In the genus Ericsonia, two species, namely, Ericsonia formosa and Ericsonia subdisticha, were recognized. Ericsonia formosa was frequent and continuously present from base to top. Ericsonia subdisticha was recorded as scarce and discontinuous in few samples.

The Noelaerhabdaceae are represented by the genus Cribrocentrum, with the species Cribrocentrum erbae and Cribrocentrum reticulatum, the genus Cyclicargolithus, with the species Cyclicargolithus floridanus, the genus Dictyococcites, with small elliptical forms (5 $\mu \mathrm{m}$ in diameter) labeled Dictyococcites sp., Dictyococcites scrippsae, and Dictyococcites bisectus, and the genus Reticulofenestra, with the species Reticulofenestra daviesii, Reticulofenestra dictyoda (gathering all specimens $<14 \mu \mathrm{m}$ ), and Reticulofenestra umbilicus. Cribrocentrum reticulatum first occurred in continuous manner from $50 \mathrm{msl}$, while $\mathrm{Cr}$. erbae had its LO at $295 \mathrm{msl}$ and showed an acme interval from $332 \mathrm{msl}$ (AB) to $348 \mathrm{msl}$ (AE). Cyclicargolithus floridanus was the most abundant taxon found (up to more than $50 \%$ ). Reticulofenestra dictyoda was common in the lower part of the section, while $R$. daviesii was very discontinuously present with low percentages, and $R$. umbilicus was discontinuous and rare in the lower part of the section and became more continuous and less rare in the upper part. Small specimens of Dictyococcites were present through all the lower part of the section, 
while Di. scrippsae and Di. Bisectus commonly and continuously occurred from $149 \mathrm{msl}$ and $154 \mathrm{msl}$, respectively.

The Discoasteraceae are represented by many species that were variably continuous and common throughout the studied sections. Diagenetic modification of the morphology frequently hampered the identification of some species; therefore, the unidentified specimens were counted as Discoaster sp. and "star-shaped Discoasterwith terminal nodes." The number of specimens varied from 1 to several dozen (maximum 149 at $109 \mathrm{msl}$ ). The more indicative species Discoaster bifax was sporadically present in the lower part of the section and had its LO at 42 msl. Discoaster barbadiensi, Discoaster deflandrei, Discoaster nodifer, Discoaster saipanensis, and Discoaster tanii occurred in discontinuous manner throughout the Baskil section.

The genus Sphenolithus was common and continuous in all the samples. Sphenolithus furcatolithoides continuously and commonly ranged from the base up to $142 \mathrm{msl}$ and very discontinuously and rarely spanned 146 msl to 206 msl. Sphenolithus obtususspanned 200.5 msl to 282.0 msl. Sphenolithus spiniger had its HCO at $188 \mathrm{msl}$, Sphenolithus predistentus first occurred at $77.5 \mathrm{msl}$ and maintained rare and sporadic occurrences throughout the section. Spotted specimens of Sphenolithus richteri and Sphenolithus runus occurred up to $58 \mathrm{msl}$, while Sphenolithus strigosus had its LO at $62 \mathrm{msl}$ and Sphenolithus radians was observed in the majority of the samples, better characterizing the lower part of the Baskil section.

The genus Nannotetrina included only Nannotetrina cristata, which was present from the base up to $40.0 \mathrm{msl}$.

The genus Helicosphaera is represented by the species Helicosphaera bramlettei, Helicosphaera compacta, Helicosphaera euphratis, Helicosphaera lophota, Helicosphaera papillata, Helicosphaera reticulata, Helicosphaera saelebrosa, Helicosphaera seminulum, and Helicosphaera wilcoxonii, which were reported as rare and discontinuous throughout the Baskil section.

The holococcoliths included the taxa Lanthernitus minutus and Zyghrablithus bijugatus. Lanthernitus minutus accounted for more than $10 \%$ in a sporadic manner from the base up to $282.0 \mathrm{msl}$ and in a continuous manner from $283 \mathrm{msl}$ up to the top of the Baskil section. Zygrhablithus bijugatus was randomly present with low percentages. 
Other taxa that were discontinuously present and in low numbers included Calcidiscus protoannulus, Pontosphaera sp., Pseudotriquetrorhabdulus inversus, and Blackites gladius(this latter only detected at $61 \mathrm{msl}$ ).

The following main bioevents were identified in the Baskil section (from bottom to top): (1) HO of Dis. bifax at $42 \mathrm{msl}$; (2) LCO of Cr. reticulatum at $50 \mathrm{msl}$; (3) HO of B. gladius at 61 msl; (4) HCO of S. furcatolithoides at $142 \mathrm{msl}$; (5) LCO of Di. bisectus at $154 \mathrm{msl}$; (6) HCO of S. spiniger at $190 \mathrm{msl}$; (7) LO of S. obtusus at $200.5 \mathrm{msl}$; (8) HO of Ch. solitus at $269 \mathrm{msl}$; (9) HO of S. obtusus at $282 \mathrm{msl}$; (10) AB of Cr. erbae at $332 \mathrm{msl}$; (11) HO of Ch. grandis at $336 \mathrm{msl}$; (12) LO of Ch. oamaruensis at $342 \mathrm{msl}$; and (13) AE of Cr. erbae at $348 \mathrm{msl}$ (Figure 23; Table 4). Following these bioevents, the lower part of the section is assigned to zones NP15 p.p. and CP14a of Martini (1971) and Okada and Bukry (1980), respectively, based on the presence of $N$. cristata and R. umbilicus. The HO of Dis. bifax marks the CP14a-CP14b zonal boundary of Okada and Bukry (1980). The HO of Ch. solitus marks the NP16-NP17 zonal boundary of Martini (1971). Following the biostratigraphical scheme of Martini (1971), we used the LO of Ch. oamaruensis to define the NP17-NP18 zonal boundary. On the other hand, following the biostratigraphical scheme of Okada and Bukry (1980), we used the HO of Ch. grandis to define the CP14b-CP15a zonal boundary (Figure 23). Following the calcareous nannofossil biostratigraphic scheme of Fornaciari et al. (2010), the Baskil section spans biozones MNP16A to MPN18B (Fig. 4). The HCO of $S$. furcatolithoides was used to define the MNP16A-MNP16Ba boundary, the LO of Di. bisectus was used to define the MNP16BaMNP16Bb boundary, the HCO of $S$. spiniger was used to define the MNP16BbMNP16Bc boundary, the LO of $S$. obtusus was used to define the MNP16Bc-MNP17A boundary, the HO of S. obtusus was used to define the MNP17A-MNP17B boundary, the AB of $\mathrm{Cr}$. erbae was used to define the MNP17B-MNP18A boundary, and the AE of Cr. erbae was used to define the MNP18A-MNP18B boundary (Figure 23; Table 4). Additionally, the recent calcareous nannofossil biostratigraphic scheme of Agnini et al. (2014) was followed, and on the basis of the recognized bioevents, the Baskil section spans zones CNE13 to CNE18. The LCO of Cr. reticulatumwas used to mark the CNE13-CNE14 boundary, the LO of Di. bisectus was used to mark the CNE14-CN15 boundary, the HO of S. obtusus was used for the CNE15-CNE16 boundary, the AB of Cr. erbae was used for the CNE16-CNE17 boundary, and the AE of Cr. erbae was used for the CNE17-CNE18 boundary (Figure 23; Table 4). 


\subsubsection{Planktonic Foraminiferal Biostratigraphy}

Planktonic foraminifera were continuously present, relatively abundant, and diverse throughout the study interval of the Baskil section, with diverse genera and species typical of middle-late Eocene low-latitude pelagic environments. Preservation varied from poor to good, but it was mostly moderate to good, therefore offering the possibility of accurate taxonomic determinations and detailed analysis of foraminiferal assemblages (not presented here). All the marker species that define the standard planktonic foraminiferal zones of Wade et al. (2011) through most of the Middle-Upper Eocene occurred in the analyzed material. The following main bioevents were identified and correlated with the planktonic foraminiferal biozones (from bottom to top): (1) LO of Orbulinoides beckmanni at $145 \mathrm{msl}$; (2) HO of O. beckmanni at 191 msl; and (3) HO of Morozovelloides crassatus at $321 \mathrm{msl}$. Following these bioevents, the Baskil section spans from E10-E11 to E14 planktonic foraminiferal zones of Wade et al. (2011). Following Wade et al. (2011), the LO of O. beckmanni and the HOs of O. beckmanni and M. crassatus were used to mark the E10-E11-E12, E12-E13, and E13E14 zonal boundaries, respectively (biozones are shown in Figure 23; Table 4)

\subsubsection{Larger Benthic Foraminiferal Biostratigraphy}

The large benthic foraminifera in the Baskil section are represented mostly by orthophragminids and nummulitids, consisting of key taxa that were recently adopted in a highresolution biostratigraphy of the Western Tethyan shallow-marine Bartonian and Priabonian sections (Özcan et al., 2006; Less et al., 2008; Less and Özcan, 2012). The large benthic foraminifera, occurring abundantly in the resedimented beds such as turbidites and debris flows, included the genera Nummulites, Assilina, Operculina, Heterostegina, Discocyclina, Nemkovella, Orbitocl ypeus, Asterocyclina, Chapmanina, Silvestriella, Pellatispira, Calcarina, and Linderina. The lowermost sample (78 msl) had an assemblage of nummulitids (Nummulites perforatusbiedai, Nummulites maximus, Assilina exponens, and Assilina schwageri) and orthophragminids (Orbitoclypeus douvillei, Orbitoclypeus haynesi, and Asterocyclina sireli), marking the Shallow-Benthic Zonation (SBZ) 16-17 transition, which corresponds to the LutetianBartonian boundary based on the biostratigraphic scheme of Serra-Kiel et al. (1998), updated by Less and Özcan (2012). 
The beds at 182, 186.5, 198, and $199 \mathrm{msl}$ consisted of an assemblage of Nummulites and orthophragminids, similar to the lowest sample, and in addition, reticulate Nummulites and Operculina ex. gr gomezi, first appearing in these levels. The reticulate Nummulites species, characterized by Nummulites garganicus and Nummulites ptukhiani (in the sense of Less and Özcan, 2012; Cotton et al., 2015) in this portion of the section, and by Nummulites hormoensis in the upper part, showed a remarkable increase in the proloculus diameter in phylogenetically linked N. garganicus-Nummulites hormoensis-Nummulites fabianii groups. These beds are confidently assigned to SBZ 17 (early Bartonian) based on the assemblage of N. garganicus, N. ptukhiani, N. perforatus-biedai, N. maximus, Nummulites biarritzensis, Nummulites striatus, Op. ex. gr. gomezi, A. schwageri, A.

exponens, and Or. douvillei.

A major change occurs at 314 and 323 msl, at which two key taxa, N. hormoensis and Heterostegina armenica, appear successively. The first appearance of Heterostegina is taken as the datum plane to mark the boundary between SBZ 17 and 18 in the Western Tethys (Less and Özcan, 2012). The reticulate Nummulites species in these levels are represented by $N$. hormoensis, a characteristic species for SBZ 18. Based on the last occurrence of Or. douvillei at $276 \mathrm{msl}$ and $N$. garganicus at $279 \mathrm{msl}$ and the first appearance of $N$. hormoensis and $H$. armenica at 314 and $323 \mathrm{msl}$, the SBZ 17-18 boundary should be placed in the interval between 279 and 314 msl. The Nummulitesspecies dominating in SBZ 17, such as N. perforatus-biedai, N. maximus, N. striatus, and $N$. biarritzensis cross the SBZ 17-18 boundary, while orthophragmines such as Asterocyclina sireli, As. alticostata, and As. kecskemetii have not been recorded in the upper part of the section. The most characteristic change in large benthic foraminifera in this part of the section is the first appearance of genus Chapmanina and Silvestriellaat 353 msl, which is recorded in SBZ 18 according to Serra-Kiel et al. (1998) and SBZ 18A according to Less and Özcan (2012). However, the Bartonian-Priabonian boundary and its correlation to the SBZ zones at present are debated (for a discussion, see Less and Özcan, 2012). According to Agnini et al. (2011), this boundary should lie close to the base of zone NP18, either at the uppermost part of zone NP17 or lower part of zone NP18. This means a reasonable portion of the "Bartonian" would be placed within the "Priabonian," and the Bartonian-Priabonian boundary will stay within SBZ 18A (also see Papazzoni et al., 2017). 


\subsubsection{Smaller Benthic Foraminifera and Paleobathymetry}

Smaller benthic foraminifera were continuously present, abundant, and diverse throughout the study interval of the Baskil section. Preservation varied from poor between 160 and $180 \mathrm{msl}$ to good in the rest of the section. The benthic foraminiferal assemblages were dominated by calcareous taxa that represented, on average, over $80 \%$ of the assemblages. Porcelaneous test wall foraminifera represented a negligible part of the assemblages. The most abundant genera were (in alphabetic order): Anomalinoides, Bathysiphon, Bulimina, Cibicidoides, Lagena, Lenticulina, Melonis, Nodosaria, Nuttallides, Oridorsalis, Praebulimina, Pullenia, Stilostomella, and Uvigerina. The dominance of calcareous taxa and the preservation state of the foraminiferal tests suggest that the depositional paleodepth throughout the studied interval was well above the calcite compensation depth and lysocline throughout the entire section. Based on the overall most common species, it is possible to make some assumptions about paleodepth. Throughout the investigated section, many taxa would occur with an upper bathyal upper depth limit or be common at bathyal depths, e.g., Cibicidoides eocaenus, Cibicidoides micrus, Cibicidoides mexicanus, Cibicidoides bradyi, Bulimina tuxpamensis, Bulimina. alazanensis, Bulimina. jacksonensis, Hanzawaia ammophila, Anomalinoides capitatus, Anomalinoides alazanensis, Osangularia plummerae, Planulina ambigua, Spiroplectammina spectabilis, Uvigerina rippensis, Uvigerina spinulosa, Nuttallides truempyi, and Globocassidulina subglobosa, along with the presence of unilocular and uniserial nodosariids. On the basis of the distribution and abundance of these species, a likely upper bathyal (-300-600 m) depositional depth can be inferred for the studied interval.

\subsubsection{Environmental Magnetism}

In Figure 27 are reported the curves of different magnetic parameters, each parameter gives information about some aspect of the magnetic mineralogy of the samples, and the comparison between them enables to recognize patterns and variations throughout the section. From left to right in the figure is shown: 
ARM curve: starting from the base of the section up to ca. $40 \mathrm{~m}$ the curve shows a slightly decrease in intensity, with a maximum value close to $0 \mathrm{~m}$, then it keeps a low intensity up to $149 \mathrm{~m}$, where there is a sharp increase in intensity, coming back to low values at ca. $170 \mathrm{~m}$. From there on, the curve is quite steady, with some isolated spikes of increased intensity at ca. $170 \mathrm{~m}, 200-210 \mathrm{~m}$ and $280-300 \mathrm{~m}$.

IRM curve: the curve shows a constant intensity of magnetization, with some small peaks in the first $70 \mathrm{~m}$, and some mayor spikes between $160 \mathrm{~m}$ and $180 \mathrm{~m}$, then starting to slightly increase toward the top of the section, with again, some isolated spikes.

S-RATIOs: the two curves present a very similar shape, with small variations along the section. The S-Ratio300 curve has a mean value of ca. 0.85 , while the S-Ratio100 has a mean value of ca. 0.5. Both curves show a sharp decrease at about 50 and $25 \mathrm{msl}$, with values falling up to 0.3 , then return to the "baseline" value. From ca.140 msl a very slight increase of the ratios can be seen, peaking at ca. $200 \mathrm{msl}$ (with isolated maximums at 0.95 for S-RATIO300 and 0.9 for S-Ratio100). The upper part of the curves show again the lower "baseline" value, but with more distinct spikes, both of lower and higher intensity, especially between $260 \mathrm{~m}$ and $290 \mathrm{~m}$. HIRMs: both curves are closely related, with HIRM100 (green curve) showing values just a little lower than those of HIRM300 (orange curve). Both of them show an almost constant behavior throughout the section, with some isolated spikes with higher values, especially in the interval between 160 and $190 \mathrm{msl}$, and again between 270 and $290 \mathrm{msl}$. Grain Size: the curve shows a mean value close to the 0 , with some spikes at higher values at $5 \mathrm{~m}$, between 40 and $60 \mathrm{msl}$, between 150 and $170 \mathrm{msl}$, and between 195 and $215 \mathrm{msl}$. Considering how the curve is build, higher values of the curve correspond to a decrease in magnetic relative grain size.

The relative concentration of different magnetic minerals across the studied section can be inferred comparing the S-Ratios and HIRMs, that represent the relative abundance between high and low coercivity minerals. The most abundant mineral present is magnetite (low coercivity, with S-Ratio300 closer to 1 ), with only some $20 \%$ or less of other minerals. As hematite is represented by small values of S-Ratios and low-mid values of HIRM, we can infer that the second most abundant mineral is hematite. Hematite becomes predominant only in two small intervals at the base of the section, between 22 and $28 \mathrm{msl}$ and between 47 to $53 \mathrm{msl}$. The presence of small variations in the S-Ratios represent a fluctuation in the sedimentary input 
at the time of deposition. The difference in value between the two S-ratios curves is relate to the relative abundance of different families of magnetite, with contrasting coercivity: namely, higher coercivity magnetite for the S-Ratio300 and lower coercivity for the SRatio100. The difference of ca. 0.4 in the two curves show how the predominant magnetite is the higher coercivity one. Comparison between the coercivity curves and the grain size show little to no correlation, indicating that any difference in grain size is not related to a different assemblage of magnetic minerals. Nonetheless, the relative grain size seems to be more correlated to the ARM curve, which should represent the relative amount of magnetic minerals in the sample, thus inferring that the finer minerals are more present during periods of high magnetic mineral concentration.

The IRM acquisition curves of selected samples show some degree of variation, but all could be fitted with four similar coercivity components (Figure 28). The first one has low component has a mean B1/2 (half-width of the Gaussian distribution of coercivity) of $\sim 10 \mathrm{mT}$, making up 4 to $20 \%$ of the magnetic assemblage. The component is probably representative of relatively coarse-grained detrital magnetite (Egli, 2004a; Savian et al., 2014). Two intermediatecoercivity componets have mean B1/2 values of $\sim 38 \mathrm{mT}$ and $\sim 140 \mathrm{mT}$ respectively, with low dispersion of the values, which is consistent with the narrow grain-size range expected for biogenic magnetite (e.g. Kruiver and Passier, 2001; Jovane et al., 2012; Savian et al., 2014). The two components can be interpreted as the so called "soft" and "hard" biogenic magnetite (Egli, 2004b), which probably correspond to different morphologies biogenic magnetite. The two intermediate-coercivity components contribute to $60-80 \%$ of the magnetic signal. The high coercivity component has a B1/2 values of $\sim 785 \mathrm{mT}$, tipical of hematite, and contribute to less than $20 \%$ to the total IRM magnetic signal. The high coercivity component coercivity, two have intermediate coercivity and one has high coercivity. The lowcoercivity has a B1/2 values of $\sim 785 \mathrm{mT}$, tipical of hematite, and contribute to less than $20 \%$ to the total IRM. The thermomagnetic curves show mineralogical transformation during the thermal treatment (

Figure 25). The heating curves commonly show an increase of values above $450{ }^{\circ} \mathrm{C}$ and then a drop after $550{ }^{\circ} \mathrm{C}$, which are consistent with the presence of low-Ti magnetite. The cooling curves have much higher values of susceptibility, probably due to a reaction of the low-Ti 
magnetite separating into magnetite (with higher susceptibility) and a high-Ti magnetite (with lower susceptibility) (e.g., Ozima and Larson, 1970).
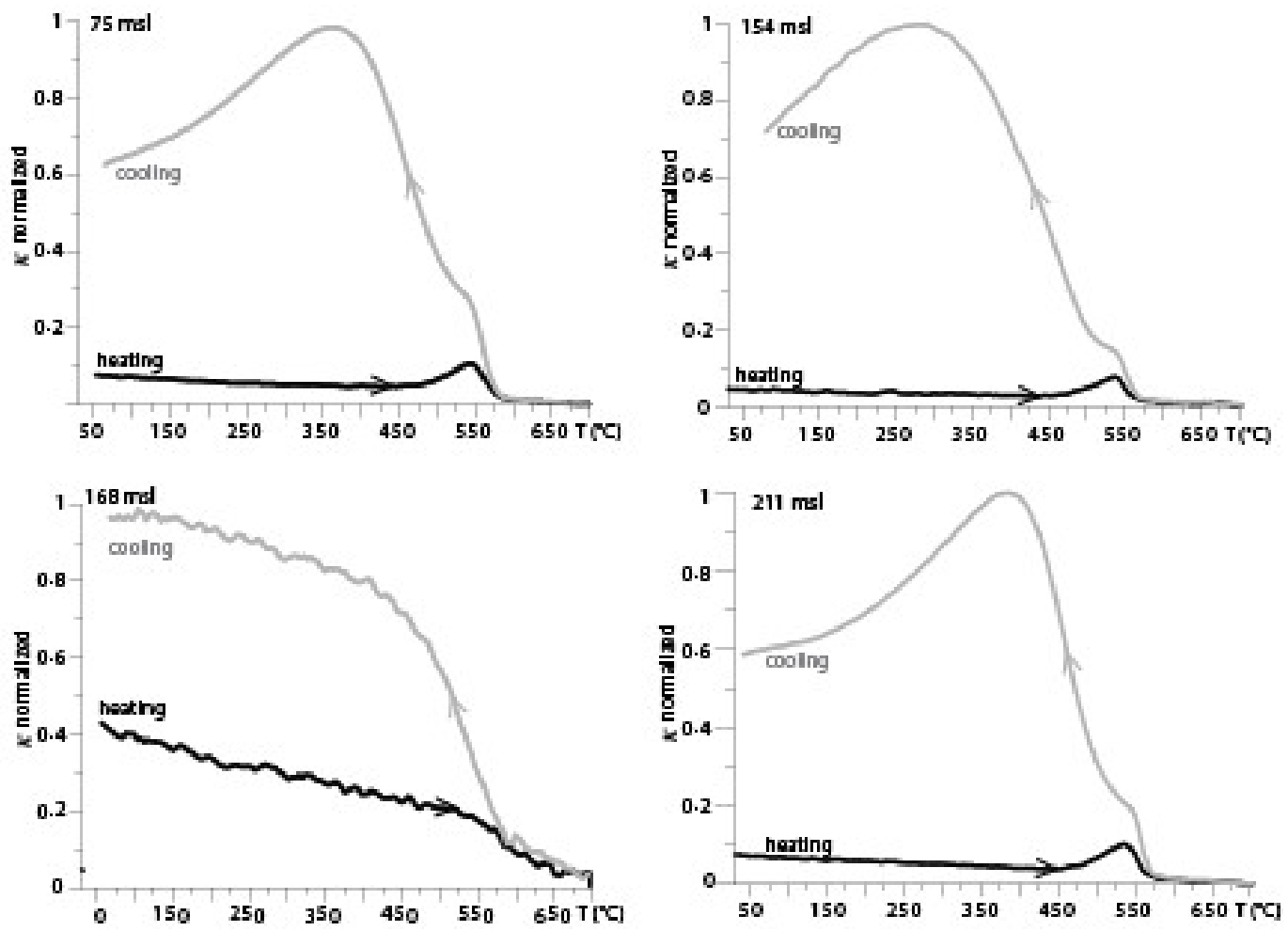

Figure 25 Susceptibility as function of temperature for 4 representative samples. Heating curves are in black, cooling curves are in grey.

\subsubsection{Correlation to the Geomagnetic Polarity Time Scale}

Following the biostratigraphic data presented herein, the magnetozones can be confidently correlated with the geomagnetic polarity time scale (GPTS) of Gradstein et al. (2012) between the base of chron C19.1n and chron C17 ( Figure 26). In detail, R1 corresponds to chron C19n.1r, N1 to chron C19n.1n, R2 to chron C18n.2n, N2 to chron C18n.2n, R3 to chron C18n.1r, N3 to chron C18n.1n, R4 to chron C17n.3r, N4 to chron C17n.3n, R5 to chron C17n.2r, N5 to chron C17n.2n, R6 to chron C17n.1r, and N6 to chron C17n.1n, as presented in Table 1. In the lower part of the section, it was possible to constrain with high confidence the boundaries of chron C19n.1n. The upper limit of this chron has been proposed by Jovane et al. $(2007,2010)$ as the boundary between the Lutetian and the Bartonian. 
Since a global stratotype section and point (GSSP) for the Lutetian-Bartonian boundary has not been assigned yet, the Baskil section might be a good candidate, because it includes highly detailed magnetostratigraphy alongside biostratigraphy for several important group fossils.

The high resolution of the sampling also allows the recognition of subchrons $\mathrm{C} 17 \mathrm{n} .1 \mathrm{r}$ and C17n.2r, which lasted only $227 \mathrm{k} . \mathrm{y}$. and $67 \mathrm{ky}$ respectively, and this is indicative of the high level of detail achievable in this section. The linear correlation between magnetostratigraphy and biostratigraphy shows some uncertainties. The age model is limited to the part of the section between $43.3 \mathrm{~m}$ and $320.6 \mathrm{~m}$. On the basis of this age model, the variation of the sedimentation rates was calculated throughout the section, and the results are reported in Table 3. The age model was tentatively extended up to $348 \mathrm{~m}$ in the section using the $\mathrm{AB}$ of $\mathrm{Cr}$. Erbae (Agnini et al., 2011) as the boundary between the Bartonian and Priabonian. The top of our studied section has an estimated age of ca. $37.8 \mathrm{Ma}$ within chron $\mathrm{C} 17 \mathrm{n}$, while the bottom sets at ca. 41.4 Ma within chron $\mathrm{C} 19 \mathrm{n}$. By extrapolating the ages from the sedimentation rates, the base of the Baskil section is ca. 42.2 Ma, while the top of the section is ca. 37.3 Ma. No faults, condensed layers, or hiatuses that might indicate a time discontinuity have been recognized throughout the section. Consequently, the entire Baskil section spans a time interval of at least 3.6 m.y. in one continuous and undisturbed high deposition sedimentary sequence. This is also corroborated by the biostratigraphic data, as detailed next. The incongruences between the age of some biozones and the magnetostratigraphy could be explained as due to the influence of some local or regional factors on the presence (or absence) of specific taxa. 


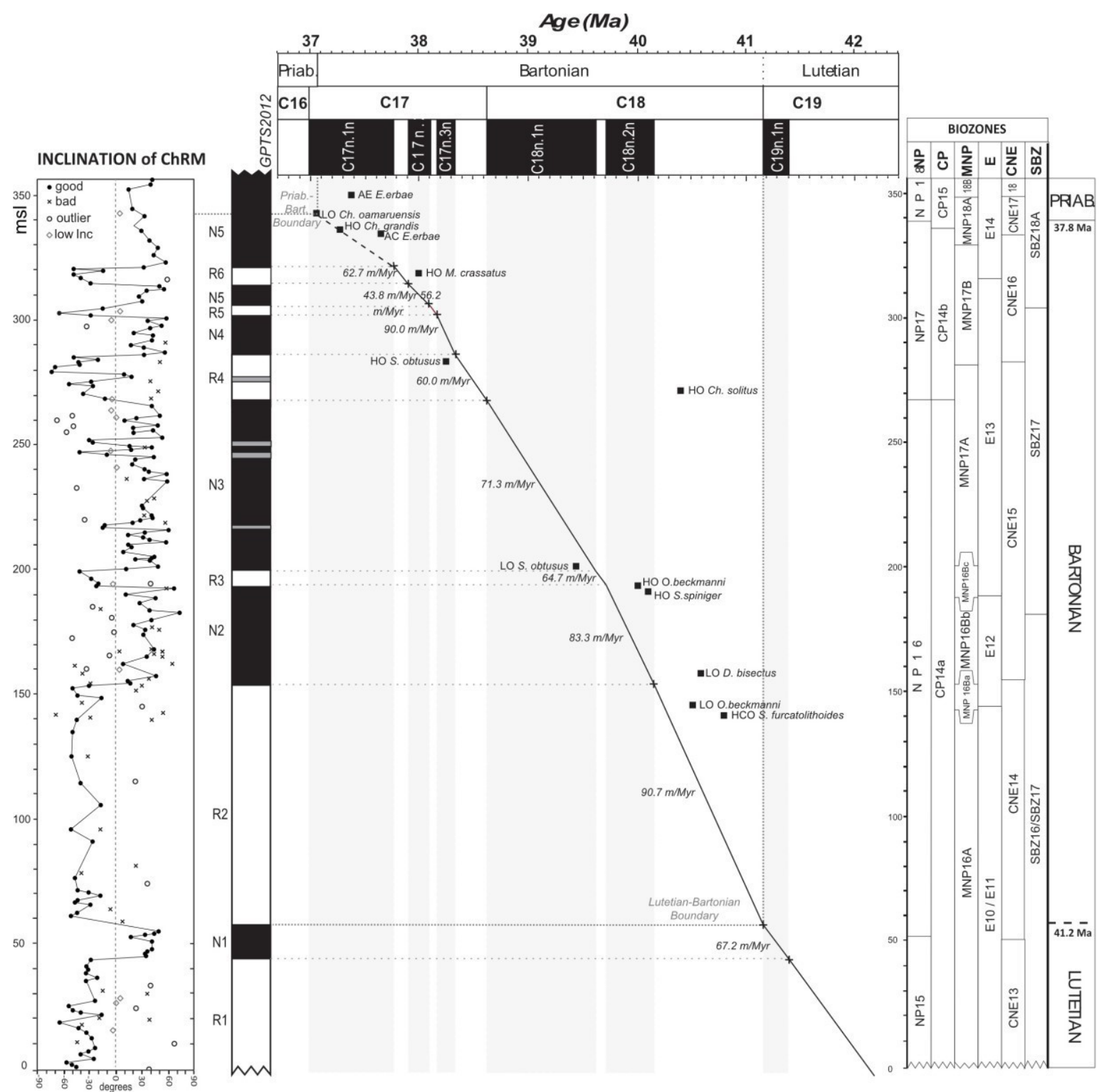

Figure 26 Inclination of characteristic remanent magnetization (ChRM) and age vs. depth plot with correlation to the geomagnetic polarity time scale (GPTS) by Gradstein et al. (2012) and to the biostratigraphic zonation of the studied section. See Figure 23 for biozones. LO-lowest occurrence; HO-highest occurrence; LCO-lowest common occurrence (defined as the lowest continuous occurrence $>1 \%$ ); HCO-highest common occurrence (defined as the highest continuous occurrence $>1 \%$ ); $\mathrm{AB}$ - acme beginning (defined on abundance $>10 \%$ ); $\mathrm{AE}-$ acme ending (defined on abundance $<10 \%$ ). Genus abbreviations: Cr. - Cribocentrum, Ch. - Chiasmolitus, M.Morzovelloides, S.-Sfenolitus, O.-Orbulinoides, Di.-Dictyococcites 

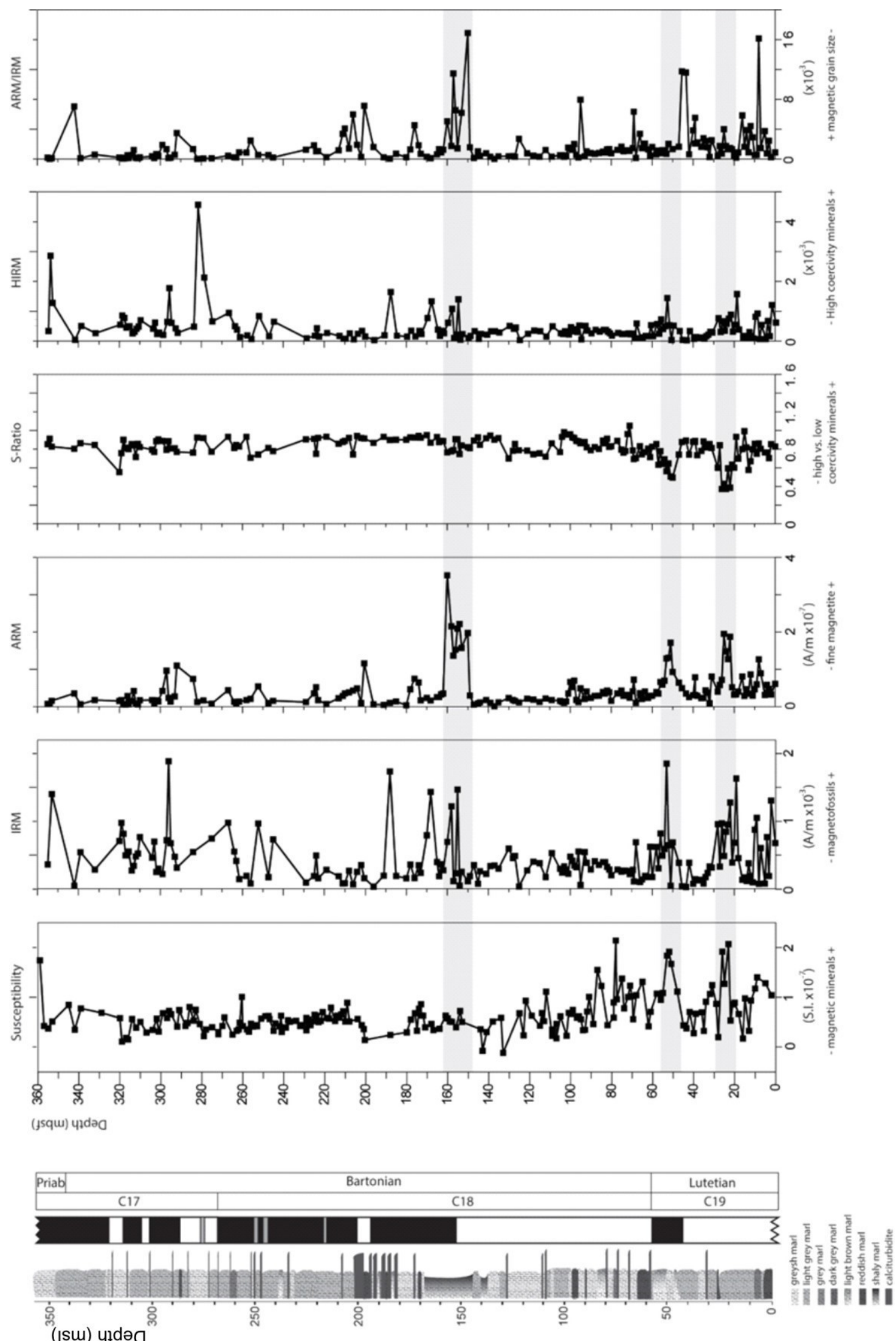
Figure 27 (previous page) Variations of environmental magnetic parameters along the studied section. The light grey bands highlight parts of increased concentration of fine magnetite. The MECO interval (as in Bohaty et al., 2003 and Jovane et al., 2007) and two short-period events in chron C19 are marked with dark a grey band.

\begin{tabular}{ccccc}
\hline Magnetozone & Chron & Base & Top & $\begin{array}{c}\text { Sedimentation } \\
\text { rate }\end{array}$ \\
\hline & & msl & mls & m/Myr \\
\hline N6 & C17n.1n & 320.6 & - & - \\
R6 & C17n.1r & 313.7 & 320.6 & 62.7 \\
N5 & C17n.2n & 305.8 & 313.7 & 43.8 \\
R5 & C17n.2r & 301.3 & 305.8 & 56.2 \\
N4 & C17n.3n & 285.1 & 301.3 & 90 \\
R4 & C17n.3r & 268.3 & 285.1 & 60 \\
N3 & C18n.1n & 199.8 & 268.3 & 71.3 \\
R3 & C18n.1r & 193 & 199.8 & 64.7 \\
N2 & C18n.2n & 153.4 & 193 & 83.3 \\
R2 & C18n.2r & 58.1 & 153.4 & 90.7 \\
N1 & C19n.1n & 43.3 & 58.1 & 67.2 \\
R1 & C19n.1r & - & 43.3 & -
\end{tabular}

Table 3 Numerical values for the sedimentation rate calculated for each subchron.
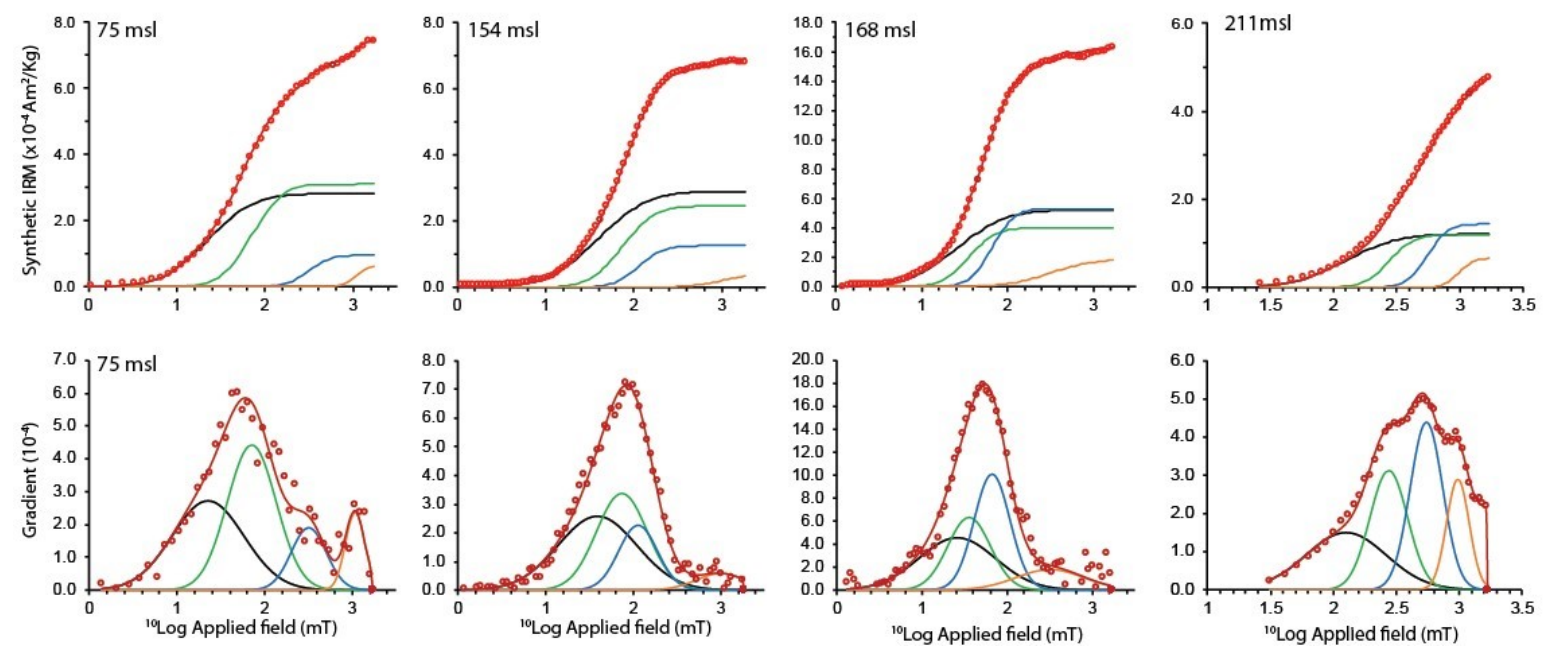

Figure 28 examples of decomposition of IRM acquisition curves for four representative samples. The black curve is the low coercivity component, blue and green curves are the two intermediate coercivity components, the yellow curve is the high coercivity component, as described in the text. 

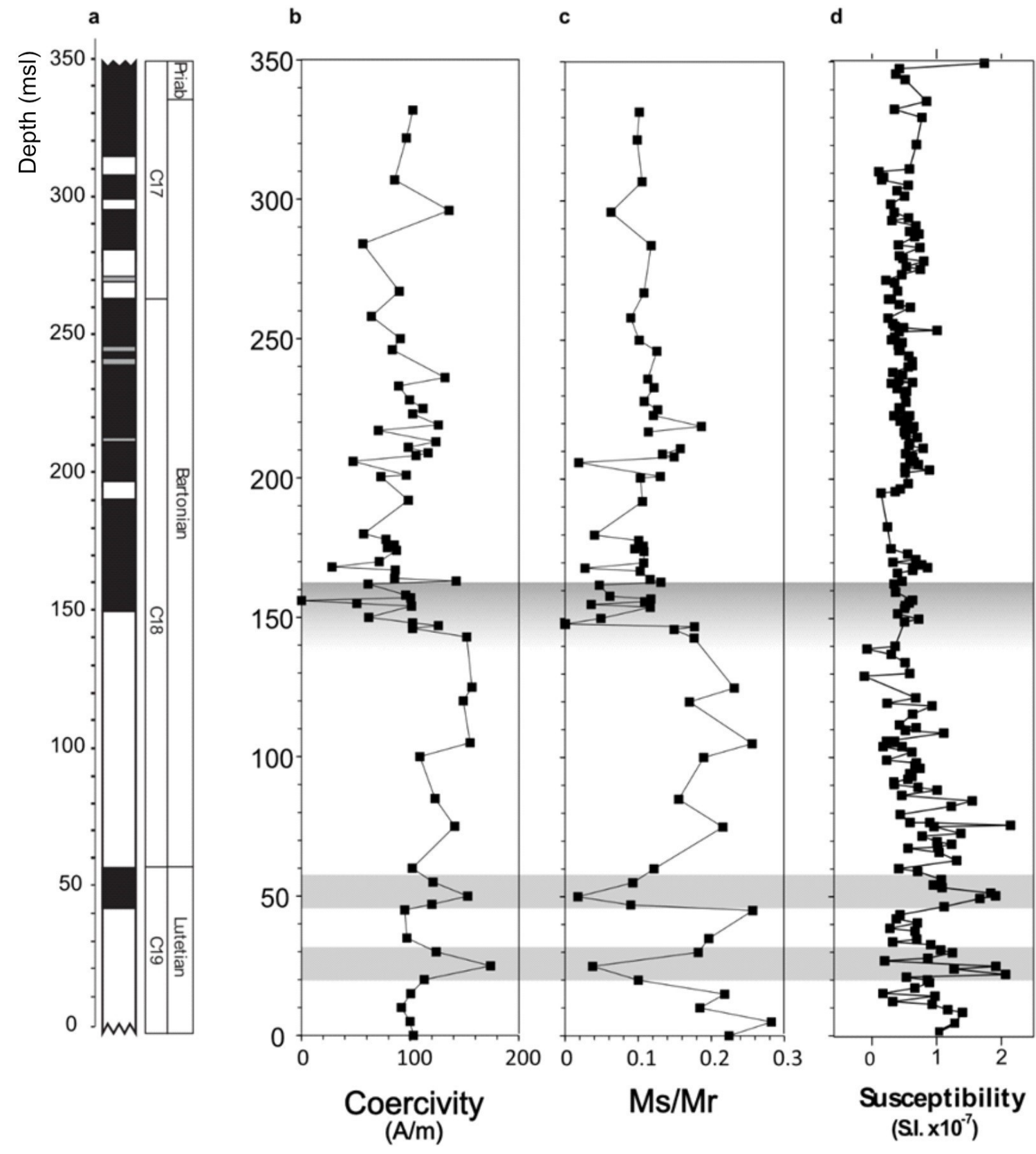

Figure 29 Rock magnetic properties of the BS. (a) Magnetic zonation and Magnetic Chrons (after Gradstein et al., 2012). (b) Magnetic coercivity, (c) ratio between magnetic saturation and magnetic remanence. Values for (b) and (c) extracted form the hysteresis loops. (c) Bulk magnetic susceptibility. The shaded grey area at $\sim 150 \mathrm{msl}$ represent the MECO period (Bohaty and Zachos, 2003; Jovane et al., 2007), while the grey bands at 25 msl and $\sim 50 \mathrm{msl}$ are short-term events during the Chron C19.

\subsection{Discussion}




\subsubsection{Biostratigraphy}

The biostratigraphic marker data that define the standard planktonic foraminiferal zones of Wade et al. (2011), as well as all those used to define the standard calcareous nannofossil zonations of Martini (1971), Okada and Bukry (1980), Fornaciari et al. (2010), and Agnini et al. (2014) through the middle-late Eocene, occur in the analyzed material of the Baskil section. Our integrated biostratigraphic study provides evidence that the $0-357 \mathrm{msl}$ interval at the Baskil section is continuous and spans planktonic foraminiferal ones E10-E11 to E14 of Wade et al. (2011), calcareous nannofossil zones NP15 to NP18 of Martini (1971), zones CP14a to CP15 of Okada and Bukry (1980), zones MNP16A to MPN18B of Fornaciari et al. (2010), and zones CNE13 to CNE18 of Agnini et al. (2014). A comparison between the ages of the biostratigraphic and magnetostratigraphic events as known from literature and calculated from the age model is summarized in Table 4.

\subsubsection{AMS and tectonic implications of the Baskil Section}

The parameters calculated from the AMS measurements suggest that the magnetic fabric is mainly of sedimentary origin, represented by a q factor of 0.191 , with virtually no syn- or post depositional tectonic overprint. The value of the shape parameter $\mathrm{T}$ of 1.0003 represents an almost perfect spherical ellipsoid, supporting the idea that the fabric has not been overprinted by compaction- or tectonic-related processes (Gilder et al., 2001). Since the fabric is of primary sedimentary origin, the $\mathrm{K} 1$ direction is expected to occur parallel to the sediment flux and perpendicular to the orogenic front (e.g., Hrouda, 1982). However, Özkul (1988) demonstrated that paleocurrents in the Elazığ Basin during the middle Eocene were directed ENE-WSW, implying that the obtained $\mathrm{K} 1$ is not perfectly aligned with the main sediment flux, but probably represents the direction of the flux in a small portion of the basin. We interpret the values of the anisotropy parameters as a signal of absence of (or very limited) tectonic stresses on the sediments both during and after deposition and lithification. This is also supported by the excellent degree of preservation and lack of any deformation of the microfossils tests.

Since no differences have been observed in the values or the directions of the anisotropy parameters with the stratigraphic position of the sample, we infer that sedimentary processes (e.g., sediment flux direction and differential compaction) remained rather constant during the 3.6 m.y. of deposition. Our in situ analyses and AMS data suggest very little deformation of 
the Baskil section. This evidence contrasts with the articulated tectonic evolution reconstructed for the basin and surrounding area, as hypothesized by the previously described tectonic models. In fact, in a convergent setting (foreland basin and/or thrust-top basin), sediments are affected by faulting and folding, even if younger growth strata can be less deformed than the substratum (particularly if the sedimentation was high). The whole succession was not affected by folding, and its deformation is represented by a gentle NNW (330 ) dip $\left(13^{\circ}\right)$ angle. Nevertheless, in a compressional setting, thickening of the original succession has to be expected due to the activity of reverse faults (Butler and Mazzoli, 2006). In this case, neither doubling of the succession nor overload of the sediments has been detected in the complete study succession. This evidence supports two main facts that have to be taken into account for a possible reconstruction of the Paleogene tectonic evolution of this area: (1) A 1250-m-thick (Calgar, 2009) continuous and undeformed succession was deposited during the late Paleocene-early Miocene in a deep-marine environment; (2) this succession was exhumed and tilted, without any other deformation at the basinal scale, except for widespread fracturing that deformed the succession after its sedimentation. This suggests that a contractional setting was unlikely during the evolution of the basin. We can speculate that the entire set of features could represent a transcurrent, rather than a pure contractional, tectonic environment, accompanied by local extensional pulses. In this view, this expanded succession, poorly deformed and deposited in a restricted area within a convergent margin, can be considered the infill of a negative flower structure (van der Pluijm and Marshak, 2003), possibly associated with a transtensive setting in a more general transpressive margin. Although this framework result is speculative, it can explain the well-documented stratigraphic features as well as the coexistence of contractional and extensional tectonics and the deformational features of the study succession. 


\begin{tabular}{|c|c|c|c|c|c|c|c|c|c|c|}
\hline $\begin{array}{l}\text { Biostratigraphic event } \\
\text { and Chron }\end{array}$ & $\mathrm{msl}$ & $\mathrm{NP}$ & $\mathrm{CP}$ & MNP & CNE & $\mathrm{P}$ & $\mathrm{E}$ & SBZ & $\begin{array}{c}\text { Gradstein } \\
\text { et al. } \\
(2012) \text { age } \\
\text { (Ma) }\end{array}$ & $\begin{array}{c}\text { Baskil } \\
\text { (Ma) }\end{array}$ \\
\hline AE C. erbae & 348.0 & & & MNP18A/MNP18B & :NE17/CNE1\& & & & & - & 37.40 \\
\hline Lo Ch. oamaruensis & 342.0 & NP17/NP18 & & & & & & & 37.80 & - \\
\hline HO Ch. grandis & 336.0 & & $\mathrm{CP} 14 \mathrm{~b} / \mathrm{CP} 15 \mathrm{a}$ & & & & & & 37.20 & 37.20 \\
\hline AB C. erbae & 332.0 & & & MNP17B/MNP18A & :NE16/CNE17 & & & & 37.60 & 37.90 \\
\hline FO Heterostegina & 321.0 & & & & & & & $\begin{array}{c}\text { SBZ17/S } \\
\text { BZ18A }\end{array}$ & 38.40 & 38.20 \\
\hline Ho M. crassatus & 321.0 & & & & & & E13/E14 & & 38.10 & 37.90 \\
\hline C17n.1r/C17n.1n & 320.6 & & & & & & & & 37.79 & - \\
\hline C17n.2n/C17n.1r & 313.7 & & & & & & & & 37.91 & - \\
\hline $\mathrm{C} 17 \mathrm{n} \cdot 2 \mathrm{r} / \mathrm{C} 17 \mathrm{n} \cdot 2 \mathrm{n}$ & 305.8 & & & & & & & & 38.14 & - \\
\hline C17n.3n/C17n.2r & 301.3 & & & & & & & & 38.20 & - \\
\hline C17n.3r/C17n.3n & 285.1 & & & & & & & & 38.38 & - \\
\hline Ho S. obtusus & 282.0 & & & MNP17A/MNP17B & :NE15/CNE1C & & & & 39.60 & 39.50 \\
\hline но Ch. solitus & 269.0 & NP16/NP17 & & & & & & & 40.40 & 38.50 \\
\hline C18n.1n/C17n.3r & 268.3 & & & & & & & & 38.67 & - \\
\hline Lo S. obtusus & 200.5 & & & MNP16Bc/MNP17A & & & & & 39.60 & 39.50 \\
\hline C18n.1r/C18n.1n & 199.8 & & & & & & & & 39.69 & - \\
\hline C18n.2n/C18n.1r & 193.0 & & & & & & & & 39.76 & - \\
\hline но O. beckmanni & 191.0 & & & & & P13/P14 & E12/E13 & & 40.00 & 39.70 \\
\hline Hо S. spiniger & 190.0 & & & MNP16Bb/MNP16Bc & & & & & 40.10 & 39.70 \\
\hline Lo $D$. bisectus & 154.0 & & & MNP16Ba/MNP16Bb & :NE14/CNE15 & & & & 40.60 & 40.10 \\
\hline $\mathrm{C} 18 \mathrm{n} \cdot 2 \mathrm{n} / \mathrm{C} 18 \mathrm{n} \cdot 2 \mathrm{r}$ & 153.4 & & & & & & & & 40.20 & - \\
\hline LO O. beckmanni & 145.0 & & & & & $\mathrm{P} 12 / \mathrm{P} 13$ & $\mathrm{E} 11 / \mathrm{E} 12$ & & 40.50 & 40.20 \\
\hline HCO S. furcatolithoides & 141.0 & & & MNP16A/MNP16Ba & & & & & 40.70 & 40.20 \\
\hline HO? B. gladius & 61.0 & NP15/NP16 & & & & & & & 43.30 & 41.10 \\
\hline C19n.1n/C18n.2n & 58.1 & & & & & & & & 41.20 & - \\
\hline LCO C. reticulatum & 50.0 & & & & CNE13/CNE1 & & & & - & 41.20 \\
\hline C19n.1r/C19n.1n & 43.3 & & & & & & & & 41.44 & - \\
\hline HO D. bifax & 42.0 & & CP14a/CP14b & & & & & & 40.40 & 41.40 \\
\hline
\end{tabular}

Table 4 Bioevent and chon boundaries, with their numerical ages. Notes: LO-lowest occurrence; HO-highest occurrence; LCO-lowest common occurrence (defined as the lowest continuous occurrence $>1 \%$ ); $H C O$ highest common occurrence (defined as the highest continuous occurrence $>1 \%$ ); AB-acme beginning (defined on abundance $>10 \%$ ); $A E$-acme ending (defined on abundance $<10 \%$ ). Genus abbreviations: Cr.Cribocentrum, Ch.-Chiasmolitus, M.-Morzovelloides, S.-Sphenolithus, O.-Orbulinoides, Di.Dictyococcites. msl-meters stratigraphiclevel from the base of the section. Calcareous nannofossil zones and subzones are after Martini (1971, listed as NP); Okada and Bukry (1980, listed as CP, Calcareous Phytoplankton); Fornaciari et al. (2010, listed as MNP); and Agnini et al. (2014, listed as CNE). Planktonic foraminiferal zones are after Wade et al. (2011, listed as E-calcareous nannofossil, Eocene, P-calcareous nannofossil, Paleocene). Larger benthic foraminiferal zones and subzones are after Serra-Kiel et al. (1998) and Less and Özcan (2012) (SBZ-Shallow-benthonic zonation). Chronostratigraphy is after Gradstein et al. (2012).

\subsubsection{Paleoenvironmental considerations}


Magnetic minerals assemblage indicates that, for most of the section, the most common minerals are fine magnetite of biogenic origin, with detrital magnetite and hematite. The relative increase in abundance of biogenic magnetite at about 25, 50, and between 150 and 170 msl can be interpreted as linked to an increase of primary production, due to Fe fertilization of the water column (e.g. Savian et al., 2014, 2016). Rego et al. (2018) presented mineralogical evidences that the MECO period in the Baskil Section was characterized by a warm and dry climate, while it was colder and wetter before and after the MECO. A dry climate suggests that chemical alteration of the source rocks was limited, nd that most of the sediments coming into the basin was transported by wind. Eolian dust is known to be a primary source of iron in the ocean, and Fe fertilization has been shown to be related to periods of high temperatures (e.g. Hesse, 1994; Yamazaki and Kawahata, 1998; Yamazaki, 2008; Roberts et al., 2011; Savian et al., 2014; Savian et al., 2016). An increase of primary productivity due to higher temperatures is expected during the MECO event, as temperatures are known to have risen about $5^{\circ} \mathrm{C}(\mathrm{Bijl}$ et al., 2010). Increased concentration of biogenic magnetite has also been reported during the MECO period in Italy (Monte Cagnero section, Savian et al., 2014) and in the Indian Ocean (Savian et al., 2016), indicating that the results from the Baskil section con be related to global changes in the climate, and not just the effect of regional variations.

SB and HB magnetite relative abundance, as inferred from decomposition of IRM, varies inside the time-frame of the MECO period. SB magnetite prevails in samples below $154 \mathrm{msl}$, while HB prevails above this depth, reaching a maximum at $168 \mathrm{msl}$, with drastic decrease of SB magnetite. As demonstrated in Chapter 3, selective oxidation of SB with respect to $\mathrm{HB}$ magnetite suggests a variation in the oxygen content in the waters. A decrease of SB, coupled with the preservation of $\mathrm{HB}$, indicate that, during the peak of the MECO, a shift toward more anoxic conditions happened. The onset of stratification of the water-column could easily explain this variation in oxygen content, as suggested by Galazzo et al. (2013) for the same period in NE Italy. Water stratification could effectively also explain the increased concentration of biogenic magnetite, as water masses with high dissolved iron content could be concentrated in a limited depth, leading to a relative increase of Fe availability and thus effectively fertilizing the area. Iron fertilization is unlikely to be related to an increase of local input of dissolved Fe, since, according to Rego et al. (2018), the MECO in this region was a dry period, therefore limiting the chemical alteration of source rocks and consequently limiting the extraction of Fe from the minerals. 
Two short-time events with high concentration of magnetic minerals happen at 21-27 msl and 47-56 msl. These intervals differ from the MECO period since the relative increase of magnetite is accompanied by an increase of high-coercivity minerals. The event at $\sim 25 \mathrm{msl}$ can be dated through extrapolation of the sedimentation rate to lasting from 41.78 to $41.69 \mathrm{Ma}$, with a duration of $\sim 90 \mathrm{ky}$. This event appears to be almost synchronous to the Calcium Accumulation Event -3 (CAE-3) described by Edgar et al. (2007) and referred to as "C19r Event". CAE-3 is considered to be an hyperthermal event happening at $\sim 41.5 \mathrm{Ma}$ by Westerhold and Rhöl (2013) and is interpreted as a sudden deepening of the CCD (calcite compensation depth) (Edgar et al., 2007), and considered by some authors to be related to the formation of modest-size ice sheets at the poles (Lyle et al., 2005). A colder climate, coupled with high humidity in the region (Rego et al., 2018) might explain why the CAE-3 event in the Baskil section is represented by an increase of high coercivity magnetic minerals, as the source rock was undergoing chemical alteration, with the consequent oxidation and hydration of primary magnetite to form hematite and/or gohetite. The second event at $\sim 50 \mathrm{msl}$ can be dated between 41.34 and $41.20 \mathrm{Ma}$, and it is not yet been described in literature. The magnetic characteristics and duration of this event are almost identical to those of the "C19r Event", suggesting the possibility of a common origin for the two, or that, given the high temporal resolution of the BS, the "C19r Event" could be actually composed of two distinct phases, previously not recognized in literature.

\subsection{Conclusions}

Here, I presented a new multistratigraphic record from the Baskil section, which encompasses the upper Lutetian-lowermost Priabonian interval from the Elazığ Basin, in eastern Turkey. The section is stratigraphically continuous, and characterized by high sedimentation rates and very little post-depositional alteration. The occurrences of several well-preserved, stratigraphically important microfossils groups alongside a clear paleomagnetic signal make this section one of the most complete archives ever described for the middle Eocene. The detailed magnetostratigraphic and biostratigraphic data allow the establishment of a robust age model, which represents an excellent framework for investigations of paleoclimatic, paleogeographic, and biotic events, due to the key geographic position at the connection between the Tethys and the Indian Oceans. 
The closure of the Neo-Tethys Ocean must clearly have affected the global water current patterns, with consequential temporary instability in the global climate. Based on environmental magnetic properties, the MECO period was characterized by high primary productivity, thanks to dissolved iron brought in the area by marine current and concentrated in a limited depth by the stratification of water. The study biogenic magnetite preservation and abundance proved to be a reliable source of indirect information about this period.

Secondarily, two short-time events have been recognized in the lower part of the section. While the lower event can be related to the already known CAE-3 of the late Lutetian, the upper one still unknown in literature. This fact can open the possibility to describe a second "hypertermal" event right before the MECO, suggesting that the global and gradual cooling trend of the Early Eocene is even more complex than previously thought.

The data also revealed that even in a very active and strongly deformational geodynamic regional setting, restricted areas can be characterized by an extensional regime and thus allow the formation of thick and undeformed sedimentary successions. This peculiarity of this sedimentary sequence might lead to the possibility to indicate the Baskil Section as the GSSP for the Lutetian-Bartonian boundary, which, as of 2018, is still not assigned.

\section{Chapter 5. Antarctica ice sheet evolution during the Upper Eocene - Middle Miocene through environmental and rock magnetic studies: example from a sedimentary core from the Ross Sea (DSDP Leg28, Site 274)}

\subsection{Introduction}

In order to comprehend recent global climatic changes, we need to reconstruct and comprehend the past climate changes in Antarctica. Today, Antarctica is a continent sheltered by a wide and thick ice sheet; however, before 2-3 Ma ago, Antarctica experienced warmer times (Zachos et al., 2001). Presently, we need to understand the causes and consequences (when, how and why) of past variations in glacial activity in Antarctica in order to predict future global changes. Coring proximal to Antarctic continent is of extreme importance because it provides

information directly related to ice expansions and retreats. For this reason, Deep Sea Drilling Program (DSDP) Expedition Leg 28 cored Site 274. 
In this chapter, I present a complete paleomagnetic study of cores from the Ross Sea (DSDP Leg28, Site 270 and Site274), which are poorly studied until now. The magnetostratigraphic record was used to provide much more reliable and higher resolution age constraint than the previously available biostratigraphy (by shipboard scientific party, Figure 30) for the environmental magnetic study. As environmental and rock magnetism are increasingly used in paleoenvironmental studies (e.g. Verosub and Roberts, 1995; Evans and Heller, 2003; Jovane et al., 2007; Suganuma et al., 2009; Liu et al., 2012), we expect to recognize patterns in the magnetic characteristics of the sediment that can be linked to known paleoclimatic events (Zachos et al., 2001; Lear et al., 2008; Coxall and Wilson, 2005). The aim of this study is to identify the signature of magnetic minerals, with special attention to biogenic magnetite, in the sediments during the formation of the Antarctic ice sheet and its history between the upper Eocene to the middle Miocene, with the long-term goal of better understanding the response of magnetotactic bacteria to extreme changes in environmental conditions.

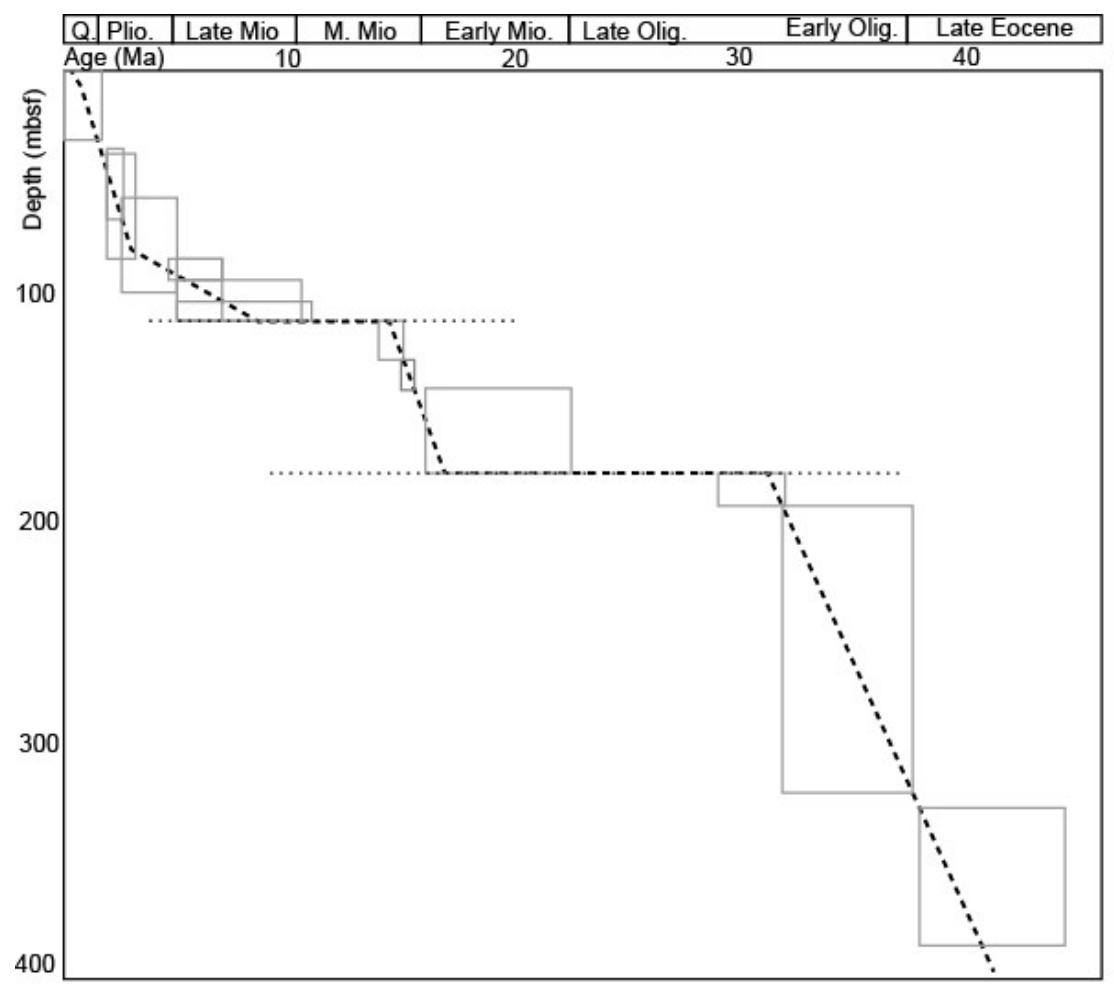

Figure 30 Original depth versus age model for hole274, as published in the shipboard report. The dotted lines represent the recognized unconformities, at $\sim 120$ and $\sim 181 \mathrm{mbsf}$. Squares represent uncertainty in the biostratigraphic data.

\subsection{Geological setting}


Hole 274 was drilled during DSDP expedition 28 in February, 1973, at coordinates 68 59.81'S, $173^{\circ} 25.64^{\prime} \mathrm{E}$, about $250 \mathrm{~km}$ north-northeast of Cape Adare (Figure 31) in a water depth of 3326 $\mathrm{m}$, with a total core length of $421 \mathrm{~m}$ and a recovery of $66 \%$.

The site lies on the lower continental rise, covered by a $500 \mathrm{~m}$ thick sediment sequence. A graben structure with relief of several hundred meters, (Houtz and Meijer, 1970), lies to the southwest of the site and probably served as an effective barrier to the downslope transport of terrigenous material. Magnetic lineations in the area suggested a late Eocene/Early Oligocene for the base of the sedimentary cover.

For this study, samples were requested from the lower part of the recovered cores, from 124 mbsl to 320 mbsf (close to the contact with basement). The portion of the sedimentary cover that was used in this work is composed of silty claystone, diatom-detrital silty clay ooze, diatom-rich silty clay, as described by the shipboard report (DSDP shipboard report). At about $180 \mathrm{mbsl}$ an unconformity is recognized cuting the stratigraphical section, with the loss of sediments between the upper Oligocene to the Lower-Middle Miocene.

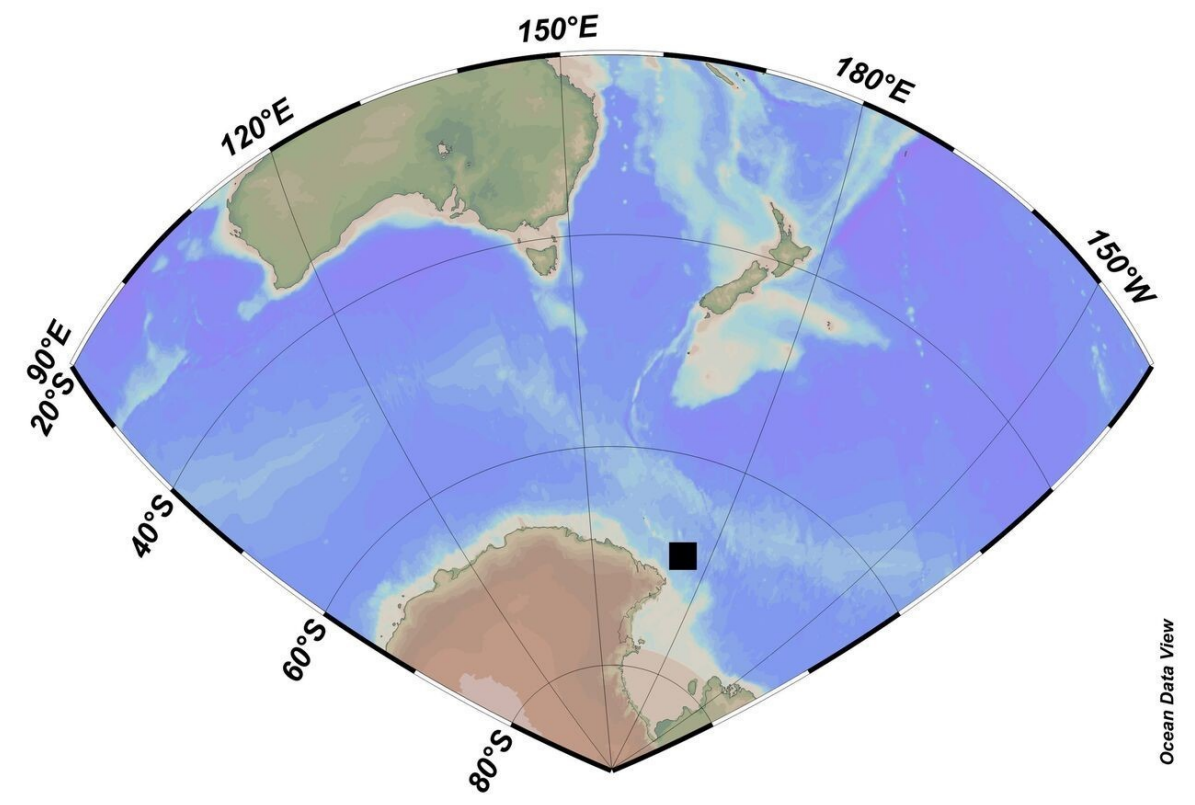

Figure 31 Position of DSDP Hole 274 NE of Cape Adare. Map generated with Oceanview software

\subsection{Materials}

In this study, standard $8 \mathrm{~cm}^{3}$ cubic oriented samples were cut from the cores and collected between 123 and 316 mbsf, with a sample every meter, or less (depending on the recovery of 
the core), for a total of 260 samples. Sampling was limited to the upper Eocene-Middle Miocene portion of the cores.

\subsection{Results}

\subsubsection{Magnetostratigraphy}

Following the PCA analysis, the majority of the samples show two componets, one, isolated up to $10 \mathrm{mT}$ of demagnetization field, is present in most of the samples with almost an horizontal inclination, while the second, which is recognizable in most samples only up to 70 $\mathrm{mT}$, is interpreted as the ChRM (Figure 32). Of the total 260 samples, only $58.8 \%$ (153) were used to define the magnetozones, while the other 107 were discarded according to the definitions given in chapter 2.1.

Mean inclinations were calculated as in Jovane et al. (2008), separately for normal and reverse polarity populations. A total of 73 (48\%) samples have positive inclinations, with a mean inclination of $46.6^{\circ}\left(\alpha_{95} 4.2^{\circ}\right)$, while 80 (52\%) show negative inclination, with a mean of -45.3 $\left(\alpha_{95} 4.5^{\circ}\right)$, suggesting that the magnetostratigraphic record passes the reversal test of McFadden and Lowes (1981). It is important to remember that, due to the way the cores were collected, it is impossible to know the original azimuthal orientation of the samples, therefore the in-situ declination is unknown.

In order to calibrate the magnetozones with the Geomagnetic Polarity Time Scale (GPTS) by Gradstein et al. (2012), we used the biostratigraphic information provided by the Shipboard Report, as no further studies on the biostratigraphy of the section have been published.

The correlation shows that the lowest magnetozone corresponds to the top of Chron C15n (34.99 Ma, Gradstein et al., 2012), at a depth of 311.3 mbsf. The period between Chron C7A (25.099 Ma) and C6 (18.748 Ma, Gradstein et al., 2012) have been lost due to the unconformity. The magnetozone R12 is the uppermost magnetozone and was correlated to the Chron C5C.1r (16.265 Ma, Gradstein et al., 2012). The results are illustrated in the depth-age model in figure 3.

Sedimentation rates have been calculated for every magnetozone (table 5), with a maximum of 33.18 during Chron C12.1n and a minimum of 1.57 during Chron C5C.1n. Following the correlation and the calculation of the sedimentation rate, the studied section encompasses 18.73 Myr, with a mean sedimentation rate of $15.3 \mathrm{~m} / \mathrm{Myr}$. 

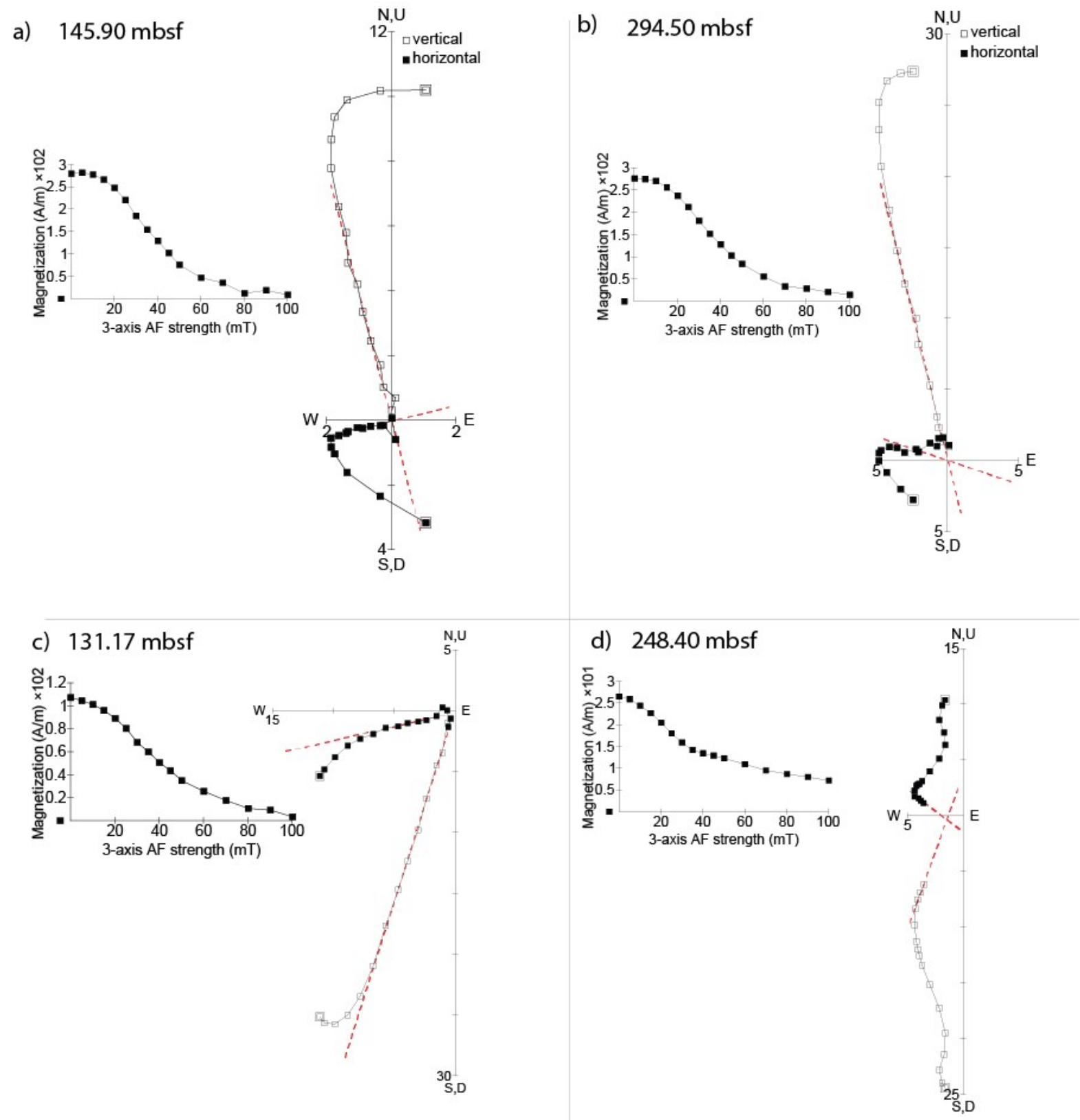

Figure 32 Examples of orthogonal demagnetization plots and intensity decay plots for AF demagnetization for 4 representative samples. Open and filled squares represent projection onto the vertical and horizontal plane, respectively. The red dotted line represents the ChRM. a), b), examples of normal polarity; c), d) examples of reverse polarity. 


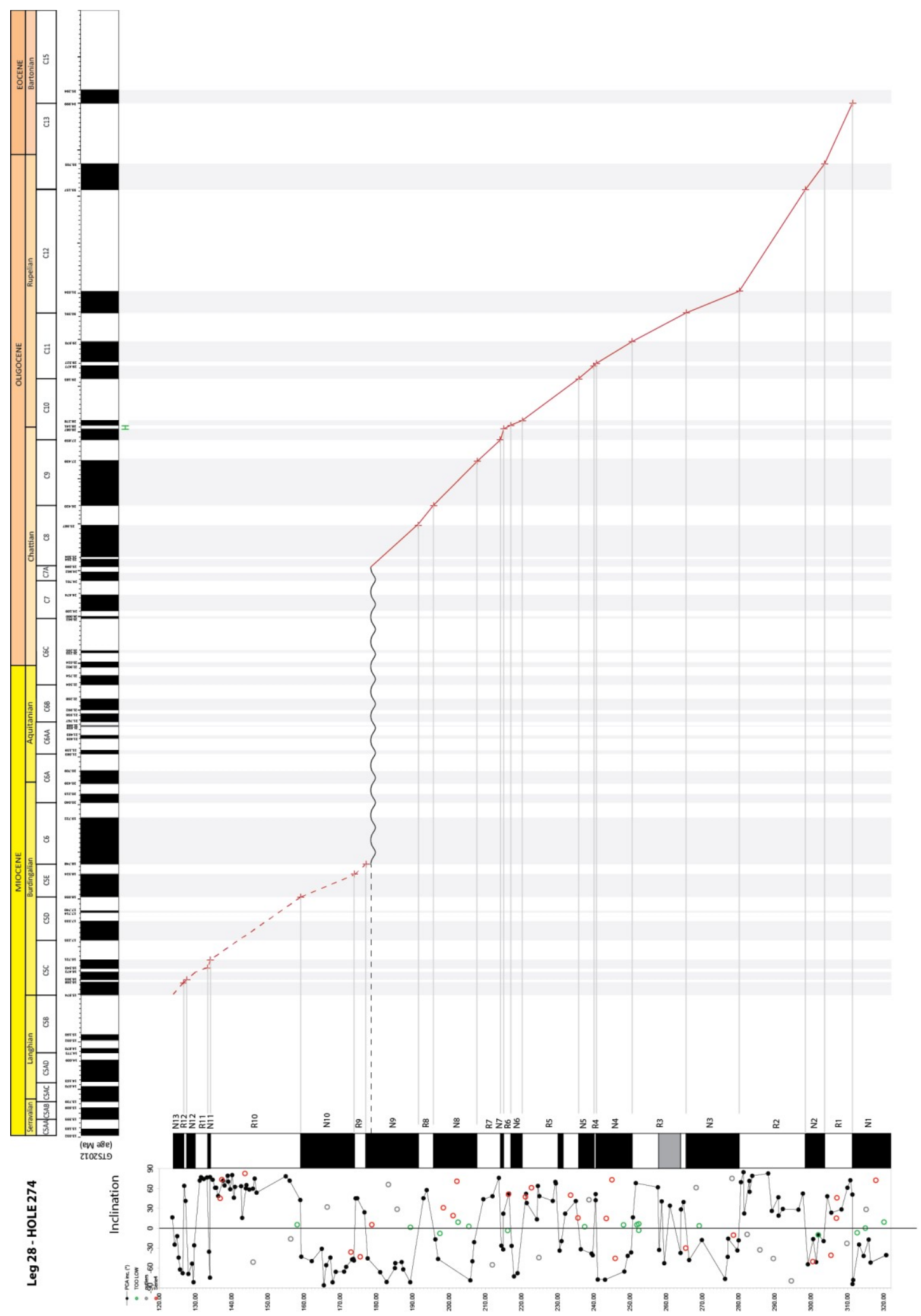

Figure 33 Inclination of ChRM and age versus depth plot with correlation to the GPTS (Gradstein et al., 2012) for Hole274. The wavy segment represents the unconformity, which spans from middle Chattian to middle Burdingalian, located at $181 \mathrm{mbsf}$. 


\begin{tabular}{|c|c|c|c|c|c|}
\hline \multirow[t]{2}{*}{ Magnetozone } & \multicolumn{2}{|c|}{ MBSF } & \multicolumn{2}{|c|}{ AGE (Ma) * } & \multirow{2}{*}{$\begin{array}{c}\text { sedim. rate } \\
\text { m/My }\end{array}$} \\
\hline & top & base & top & base & \\
\hline N13 & 120 & 126.8 & & 16.72 & 0.41 \\
\hline$R 12$ & 126.8 & 127.6 & 16.72 & 17.23 & 1.57 \\
\hline$N 12$ & 127.6 & 130 & 17.23 & 17.53 & 8.00 \\
\hline$R 11$ & 130 & 134.2 & 17.53 & 17.71 & 23.33 \\
\hline$N 11$ & 134.2 & 135.1 & 17.71 & 17.74 & 30.00 \\
\hline$R 10$ & 135.1 & 159 & 17.74 & 18.74 & 23.90 \\
\hline$N 10$ & 159 & 174.9 & 18.74 & 19.72 & 16.22 \\
\hline$R 9$ & 174.9 & 177 & 19.72 & 20.4 & 3.09 \\
\hline N9 & 177 & 191.6 & \multicolumn{2}{|c|}{ unconformity } & - \\
\hline$R 8$ & 191.6 & 195.7 & 25.98 & 26.42 & 9.32 \\
\hline N8 & 195.7 & 207.8 & 26.42 & 27.43 & 11.98 \\
\hline$R 7$ & 207.8 & 214.1 & 27.43 & 27.85 & 15.00 \\
\hline$N 7$ & 214.1 & 215 & 27.85 & 28.08 & 3.91 \\
\hline$R 6$ & 215 & 217 & 28.08 & 28.14 & 33.33 \\
\hline N6 & 217 & 220.1 & 28.14 & 28.27 & 23.85 \\
\hline R5 & 220.1 & 235.9 & 28.27 & 29.18 & 17.36 \\
\hline N5 & 235.9 & 240 & 29.18 & 29.47 & 14.14 \\
\hline$R 4$ & 240 & 240.7 & 29.47 & 29.52 & 14.00 \\
\hline N4 & 240.7 & 251.7 & 29.52 & 29.97 & 24.44 \\
\hline$R 3$ & 251.7 & 265.4 & 29.97 & 30.59 & 22.10 \\
\hline$N 3$ & 265.4 & 280 & 30.59 & 31.03 & 33.18 \\
\hline$R 2$ & 280 & 298.3 & 31.03 & 33.15 & 8.63 \\
\hline N2 & 298.3 & 303.8 & 33.15 & 33.7 & 10.00 \\
\hline$R 1$ & 303.8 & 311.3 & 33.7 & 34.99 & 5.81 \\
\hline$N 1$ & 311.3 & 322 & 34.99 & - & - \\
\hline
\end{tabular}

Table 5 Definition of magnetozones for Site 274, and relative sedimentation rate. *Age (Ma) according to the GPTS of Gradstein et al. (2012)

\subsubsection{Environmental magnetism}

Magnetic mineral abundance parameters are NRM, Susceptibility, ARM and IRM and ratios between them: these curves show similar behavior between themselves throughout the section (Figure 34). The values start high for the first 10 meters, then decreases drastically up to the middle of the section, where they increase again, followed by a sharp decrease up to the unconformity. From there, the values steadily increase again, reaching the same values of the middle and bottom parts. It is important to note that the curves are quite irregular, especially 
the NRM and ARM, with several isolated spikes. IRM@1.0 peaks represent specifically an increase of SD (or PSD) grains (Evans and Heller, 2003).

S-Ratios give information about the relative concentration of high and low (for S-Ratio300) and middle and low (S-Ratio $\left.{ }_{100}\right)$ coercivity minerals. The two curves have a similar behavior, with almost constant values close to 1 for the S-Ratio300 and 0.7 for the S-Ratio100 throughout the section, except for the interval between 175 and $145 \mathrm{mbsf}$ where de values decrease to 0.8 and 0.4 respectively. Again, the curves are dotted with spurious positive and negative spikes. Sratio values are consistent with magnetite-dominated samples.

HIRM, which gives information about the presence of high coercivity minerals, show some similar characteristics with NRM, susceptibility, ARM and IRM curves, beginning with high values in the lowermost part, followed by generally low values, throughout the most of the section, with an increase that starts at ca. 170 mbsf, reaching a maximum value in the topmost part. HIRM positive peaks are consistent with an increase of hematite concentration in the sediments.

Magnetic grain size curve shows little variation along the sequence, with slightly lower values at the bottom, and a very slightly increase after the unconformity, then coming back to lower values just before the top of the section. 

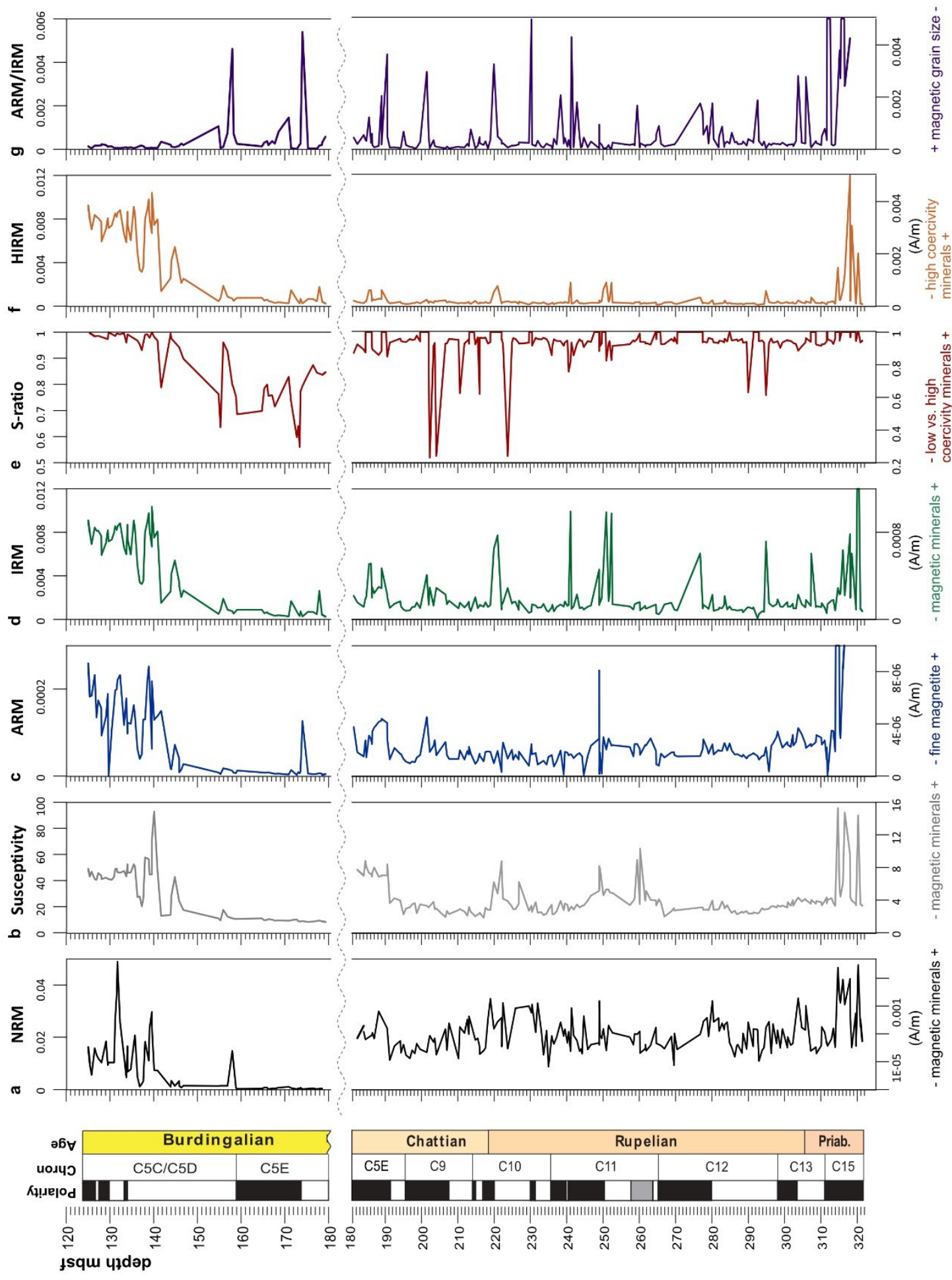

Figure 34 (previous page) Environmental magnetic properties of the studied section. Chrons are as in Gradstein et al., 2012; a-g) environmental magnetic parameters and their variation along the section. The curves are split in two parts, at the erosion surface, in order to show more clearly the difference in values of the curves. 


\subsubsection{Rock magnetic properties}

IRM acquisition of selected samples corresponding to intervals of high $\chi$, ARM, IRM, HIRM and lower S-ratios (from here "pattern 1show a common behavior, and were fitted with 5 coercivity components (Figure 34): one of very low coercivity (mean $8 \mathrm{mT}$ ) and high dispersion (0.30) and one of mid-low coercivity (mean $23 \mathrm{mT}$ ) and medium dispersion (0.23) are interpreted as different families of detrital magnetite, while the two middle-coercivity components show values consistent with biogenic magnetite, (mean coercivity $45 \mathrm{mT}$, dispersion $0.19,100 \mathrm{mT}$ and 0.15 respectively). These components are assumed to represent low-coercivity biogenic magnetite (soft biogenic magnetite of Egli, 2004b; 2004c) and highcoercivity biogenic magnetite (hard biogenic magnetite, Egli, 2004b; 2004c). The fifth component, with mean coercivity of $280 \mathrm{mT}$ and dispersion of 20, is interpreted as hematite. The overall contribution to the magnetic assemblage in these samples from the biogenic magnetite is less than $35 \%$, with more $64 \%$ linked to detrital magnetite. Hematite only represent $2-3 \%$ of the total contribution. FORC diagrams (Figure 35) of these samples show a central ridge limited to low-medium coercivity values (maximum of 100mT), with some interaction at low coercivities. Overall, the results can be interpreted as related to the presence of collapsed biogenic magnetite chains and low coercivity SD magnetite, in accordance with the results of IRM decomposition.

IRM acquisition curves for samples from intervals with low $\chi$, ARM, IRM, HIRM, and higher S-ratios ("pattern 2") were fitted with only 4 components (Figure 35): the component whose value correspond to those of soft biogenic magnetite is missing, while the hard biogenic magnetite is less abundant, corresponding to only $10 \%$ of the magnetic signal, which is largely dominated $(86 \%)$ by detrital magnetite. Hematite in these samples is slightly less abundant $(12 \%)$. Magnetic saturation values for these samples are 10 to 30 times lower than those of the first group, indicating a very low concentration of magnetic minerals. FORCs (Figure 35) of these samples were affected by the very low concentration, in fact, in the same condition of measurement, i.e. number of stacked FORCs, no distinctive feature was recognized.

Low-resolution FORCs were measured and PCA analyzed after the environmental magnetic properties were studied, thus permitting to select the best candidate for the measurements (Figure 36). The upper part of the section (middle Miocene) was selected to be studied in detail with the PCA analysis because of the high NRM and susceptibility values, that indicate a higher 
concentration of magnetic minerals, and thus increasing the possibility of obtaining meaningful data even from a relatively low-resolution measurement. PCA analysis permitted to recognize the contribution two components (or end-members, E.M) in the FORCs data. The first end member (E.M.1) was recognized as a component with almost no magnetic interaction and coercivity between 20 to $80 \mathrm{mT}$, consistent with biogenic magnetite (Egli, 2004b), while a second component (E.M.2) with high interaction and very low coercivity, was interpreted as detrital, superparamagnetic magnetite (Figure 37). While the second component abundance is relatively constant along the section of the core analyzed, the first component varies in abundance, at times constituting $85 \%$ of the magnetic signal. Comparison with environmental magnetic curves and PCA separated end-members show that increases in environmental and rock magnetic parameters are correlated with an increase of biogenic magnetite in the sediment.
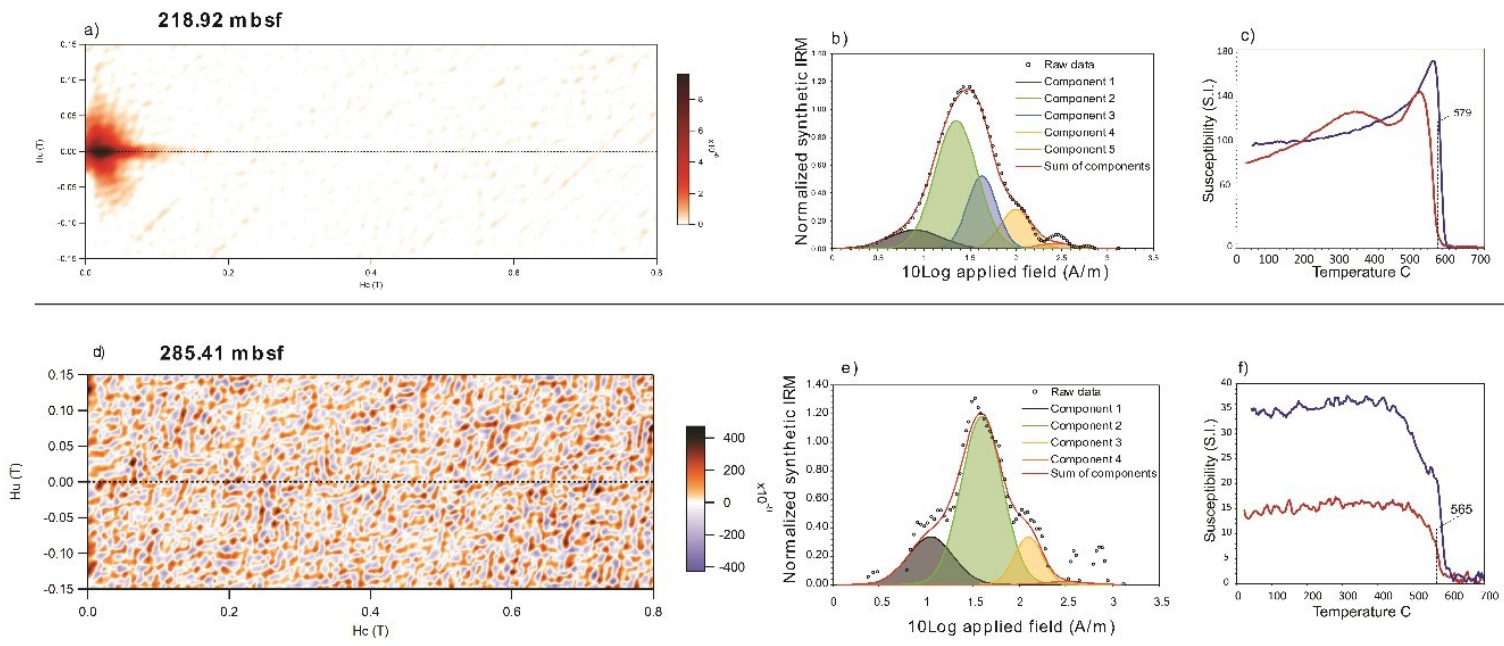

Figure 35 rock magnetic properties of two selected samples. (a), (d) FORC diagrams (note the different color scale), the input parameters are the following: $\mathrm{H}_{\mathrm{c} 1}=0 \mathrm{mT}, \mathrm{H}_{\mathrm{c} 2}=800 \mathrm{mT} ; \mathrm{H}_{\mathrm{u} 1}=-150 \mathrm{mT}, \mathrm{H}_{\mathrm{u} 2}=+150 \mathrm{mT}, 297$ cycles. (b), (e) IRM acquisition curves gradient with the separated components. Black component: low coercivity detrital magnetite, blue and green components: biogenic magnetite; orange conponents: hematite. (c), (f) thermomagnetic curves, the red curve represent the heating portion and the blue line the cooling portion of the cycle. 
a
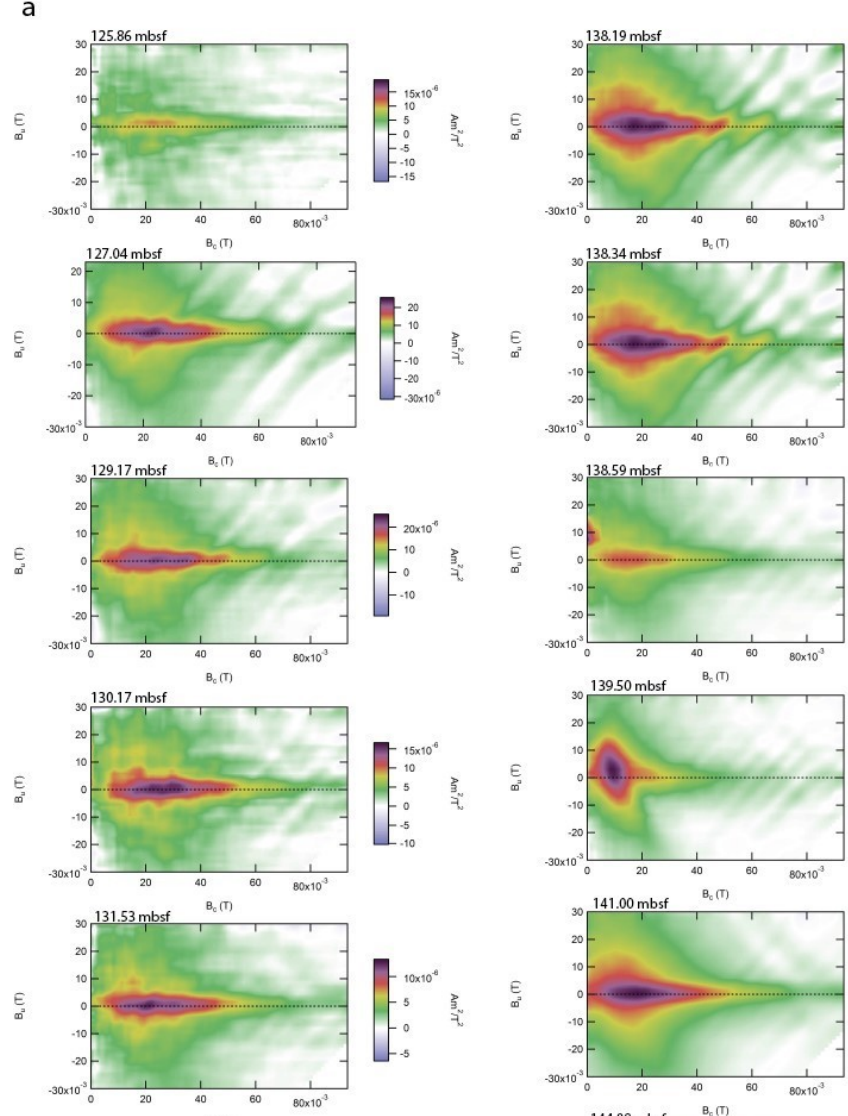

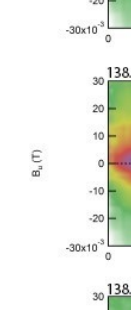
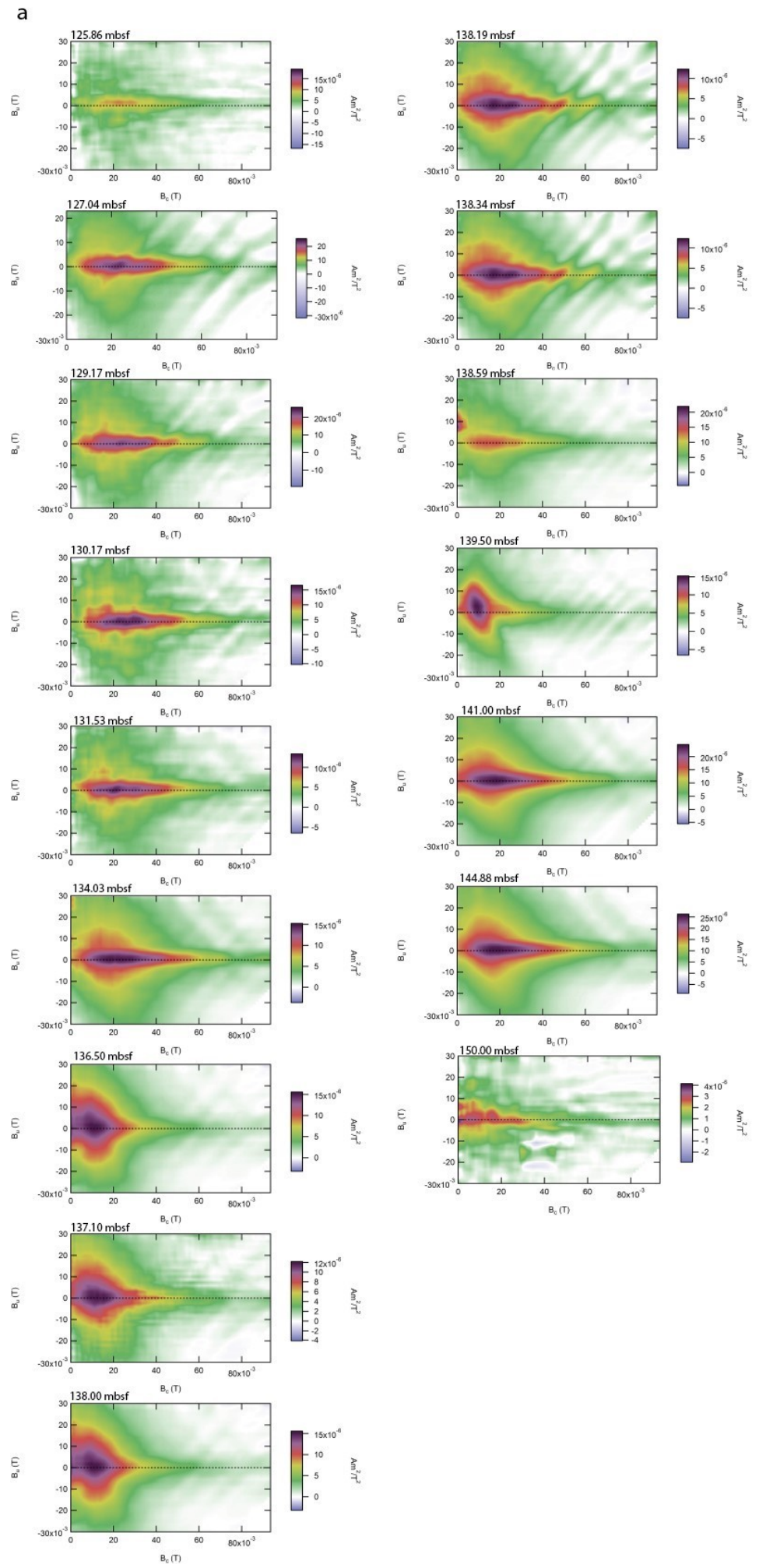

Figure 36 a) low resolution FORC diagrams of samples from the top part of the core, used for the PCA analysis. the input parameters are the following: $\mathrm{H}_{\mathrm{c} 1}=0 \mathrm{mT}, \mathrm{H}_{\mathrm{c} 2}=110 \mathrm{mT} ; \mathrm{H}_{\mathrm{u} 1}=-15 \mathrm{mT}, \mathrm{H}_{\mathrm{u} 2}=+15 \mathrm{mT}, 100$ cycles; $\mathrm{b}$ ) synthetic FORC diagrams representing the two end-members. 

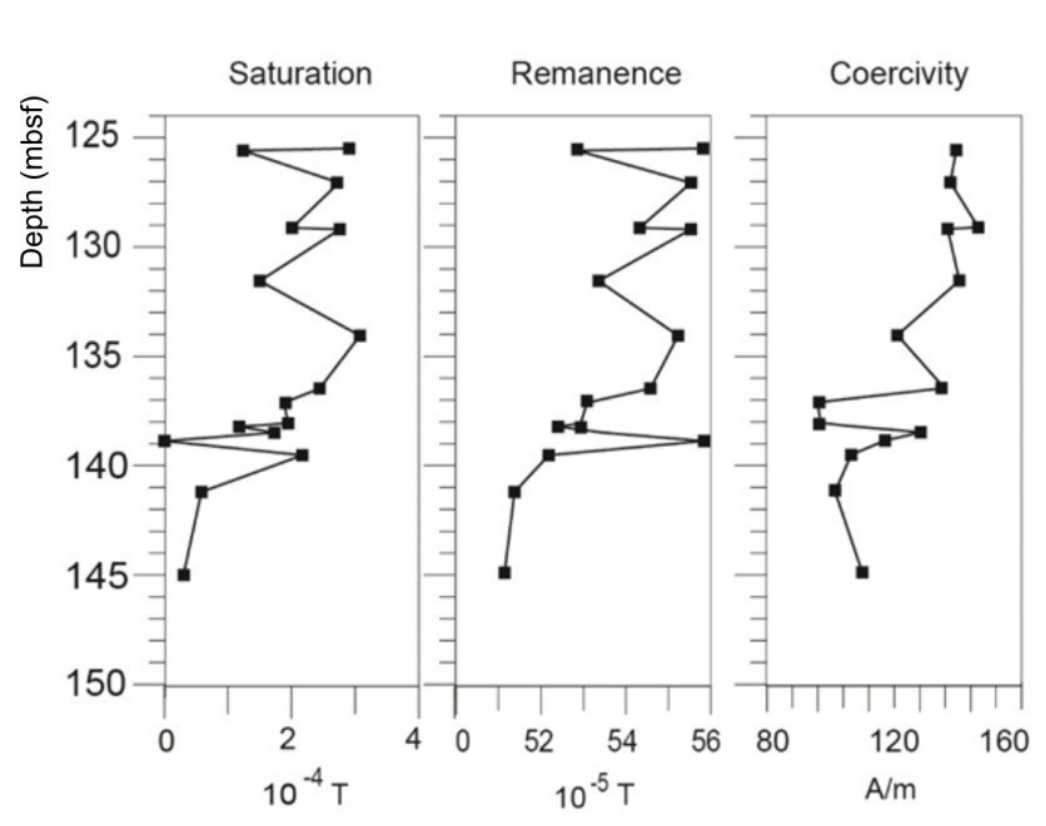

PCA

relative abundance

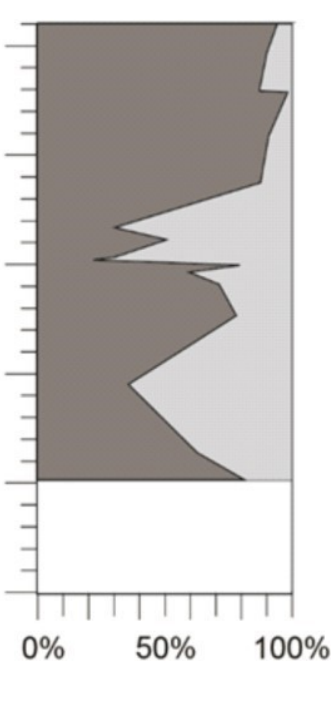

Figure 37 rock magnetic properties of the Miocene part of Site274: Magnetic saturation, magnetic remanence, magnetic coercivity, Principal Component Analysis of low-resolution FORC diagrams expressed as contribtion relative to total magnetization: dark grey represents noninteractic, SD magnetite, light grey represents interacting SP detrital magnetite.

\subsubsection{XANES spectra}

Five representative samples have been selected and prepared for XANES spectrum acquisition (Figure 38). Of the five samples, three represent samples from the "pattern 1" and two from the "pattern 2". The position of the main edge peak is centered on $7131 \mathrm{eV}$ (Table 6), as observed in the XANES spectrum of cultivated M. australis (as shown in chapter 3), but in comparison, they lack a clear peak at $7146 \mathrm{eV}$. The first derivative of the spectra (Figure 38b) has an average main peak position of $7121.7 \mathrm{eV}$, with the sample at $131.5 \mathrm{mbsf}$ having the highest value at $7124.21 \mathrm{eV}$. The position in energy of the main peak is associated with oxidation state of $\mathrm{Fe}$, and the calculated values are consistent with the results from $\mathrm{M}$. australis spectrum, so the samples are enriched in $\mathrm{Fe}^{2+}$.

The pre-edge portion of the spectra show great variability among the samples not in terms of $\mathrm{eV}$ but in terms of energy. Higher relative intensity of the pre-edge peak is related to structural disorders of the crystals (Joseph et al., 2010), while the position in $\mathrm{eV}$ is related to coordination number of Fe. The pre-edge peaks are all centrered on $7114.6 \mathrm{eV}$, slightly higher than the 7114 $\mathrm{eV}$ of M. australis (Wilke et al. 2010; Balasubramanian et al., 2014), as expected given the presence of detrital minerals with various Fe-oxidation states together with biogenic magnetite 
The relative height of the pre-peaks show that samples from "pattern 1" have lower degree of crystal order, implying that the material was not subject to any form of partial recrystallization.
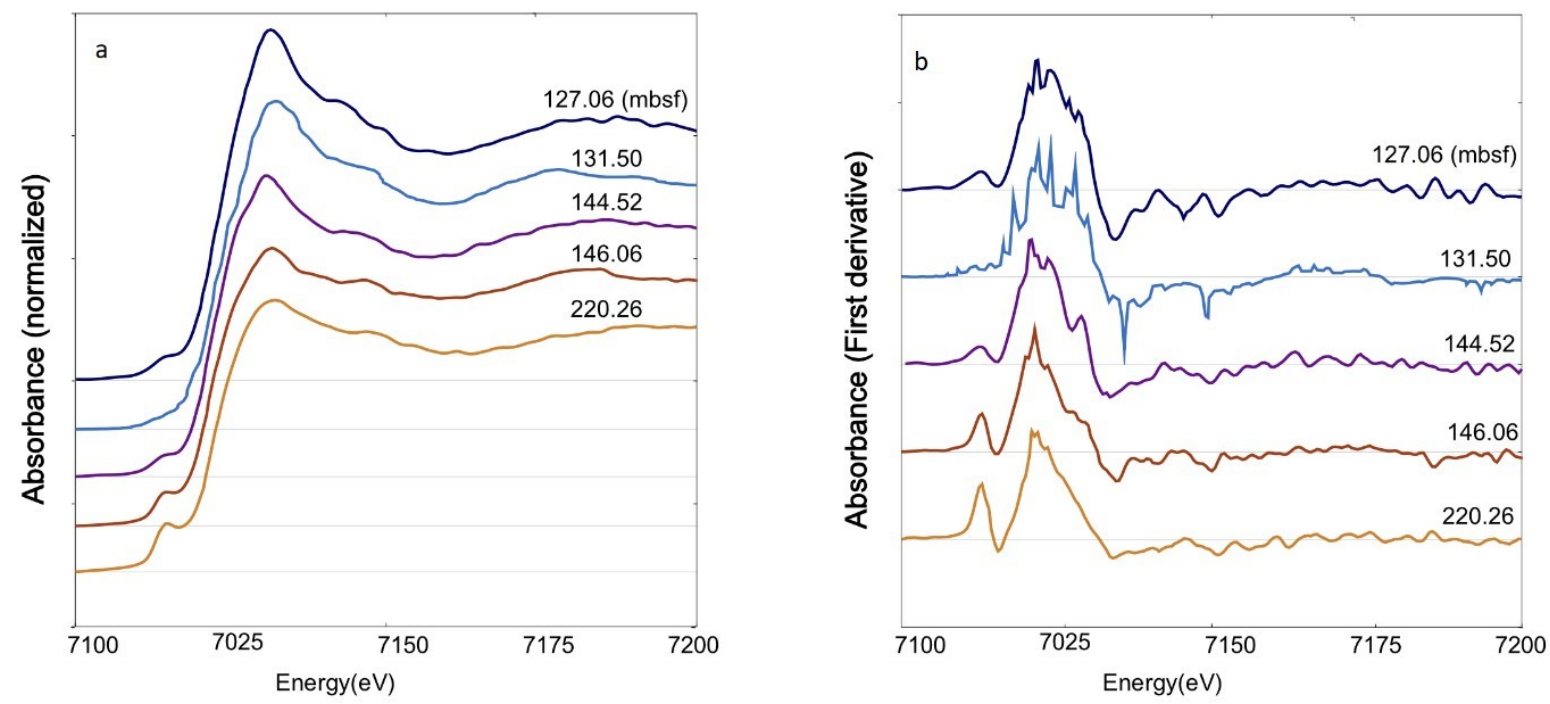

Figure 38 (a) Normalized XANES spectra of 5 selected samples from Site274. (b) First derivative of the spectra, used to highlight the relative height peak of the pre-edge features.

\begin{tabular}{|c|c|c|c|c|c|c|}
\hline \multirow[b]{2}{*}{$\begin{array}{c}\text { Sample } \\
\text { mbsf }\end{array}$} & \multirow[b]{2}{*}{ pattern } & \multicolumn{2}{|c|}{ Energy } & \multicolumn{2}{|c|}{ First derivative } & \multirow[b]{2}{*}{$\begin{array}{c}\text { Pre-edge intensity } \\
\text { normalized }\end{array}$} \\
\hline & & $\begin{array}{c}\text { Pre-edge } \\
\text { eV }\end{array}$ & $\begin{array}{c}\text { Edge } \\
\text { eV }\end{array}$ & $\begin{array}{c}\text { Pre-edge } \\
\text { eV }\end{array}$ & $\begin{array}{c}\text { Edge } \\
\text { eV }\end{array}$ & \\
\hline 127.06 & 2 & 7114.62 & 7131.35 & 7113.16 & 7121.01 & 0.1 \\
\hline 131.5 & 2 & - & 7131.21 & 711.9 (?) & 7124.21 & - \\
\hline 144.52 & 1 & 7114.5 & 7130.54 & 7112.37 & 7121 & 0.09 \\
\hline 146.06 & 1 & 7114.63 & 7131.6 & 7112.79 & 7120.86 & 0.14 \\
\hline 220.26 & 1 & 7114.58 & 7131.68 & 7112.98 & 7121.59 & 0.22 \\
\hline
\end{tabular}

Table 6 Numerical values for the energy of edge and pre-edge features of the samples, extracted from XANES spectra. The pre-edge intensity calculated after the normalization of the spectra.

\subsection{Discussions}

The two patterns recognized in the behavior of environmental parameters indicate that during the studied time interval there is an alternation between low-abundance, detrital magnetitedominated magnetic particles and high-abundance, biogenic magnetite-enriched 
magnetic particles. Due to a non-optimal recovery during the coring, the alternation could not be followed uniformly along the whole section.

Yamazaki (2012) observed that "soft" biogenic magnetite prevails under iron-reducing conditions, while disappears during anoxic events, which suggests that in our case periods of lower temperatures coincide with more anoxic waters, and periods of warmer temperatures with more oxygenated waters.

The increase in biogenic magnetite is generally linked to an increase of sedimentary discharge that fertilized the ocean with Fe (e.g. Hesse, 1994; Yamazaki and Kawahata, 1998; Yamazaki, 2008; Roberts et al., 2011; Savian et al., 2014, 2016). HB and SB magnetite concentration is related to oxygen abundance and availability the water, as demonstrated in chapter 3 . In the case of Site 274, high concentration of biogenic magnetite, specially of SB type, is always associated with high general magnetic mineral concentration and relatively low concentration of high coercivity minerals. It is possible to infer that during these periods, oxygenation of the water was high enough to support the presence of MTB synthetizing SB magnetite, while low concentration of magnetic minerals suggests a reduced input of sediments in the basin. The highest values of relative magnetic mineral abundance and high concentration of MTB happen in concomitance with known periods of warm climate, the late Eocene at the base of the section and the MMCO at the top. It is therefore possible to define epochs of warm climate as periods with high Fe fertilization and high acumulation of biogenic magnetite, while epochs of cooler climate with periods of very low Fe fertilization and generally very low input of detrital material.

It can be assumed that during a glacial period there was lower sediment input into the basin, carring prevalently detrital magnetite, while interglacial periods resulted in an increase of terrestrial material input, due to discarge of sediments stripped by the galciers and freed by the melting ice. Increase of magnetic mineral concentration has been shown to be coincident with an increase in biogenic magnetite during warmer periods such as the MECO (middle Eocene Climatic Optimum, as in Savian et al., 2016) or the PETM (Paleocene Eocene Thermal Maximum, as in Larassoaña et al., 2012). During periods of cooler climate, the disappearance of BS magnetite but not of HB magnetite imply lower values of oxygenation in the water column, either from increased accumulation of organic matter or stratification of the water column, with subsequent selective dissolution of specific morphologies of biogenic magnetite (Egli, 2004c, Yamazaki, 2012). 
This study identifies the signature of magnetic minerals, with special attention to biogenic magnetite, in the sediments during the formation of the Antarctic ice sheet and its history between the upper Eocene to the middle Miocene, with the long-term goal of better understanding the response of magnetotactic bacteria to extreme changes in environmental conditions. Our results confirm the absence, at high latitudes, of a prolonged warm and stable phase during the Miocene, unlike to what is observed at low and middle latitudes (Zachos et al., 2001 and references therein). Miocene is characterized by long-term colder periods and short warmer periods.

\subsection{Conclusions}

I presented a new magnetostratigraphic and environmental magnetic properties study for an upper Eocene to middle Miocene sedimentary section cored in the Ross Sea. The magnetostratigraphy served as a base to calibrate the age of the variations in the magnetic parameters. Periodical variations in the global ocean temperature influenced the extention of the Antarctic ice sheet, that in turn controlled the transport of terrigenous material into the basin. The influence of the oscillations in the Antarctic ice sheet produced marked differences in the magnetic mineral assemblages along the stratigraphic section, with periods of warmer and cooler climate recognizable as a general increase of biogenic magnetite and decrease of biogenic magnetite, respectively. Fertilization of the water, that ultimately controls the production of biogenic magnetite, was probably carried during mass discarge of sediment from the retreating ice sheet, instead of dust transported wind as more commonly the case.

These insights are invaluable because they demonstrate that prior to the Middle Miocene Climatic Optimum $(\sim 15 \mathrm{Ma})$, there has been a period of climatic instability modulated by longterm variations with phases of glacial advance and retreat in the Ross Sea area of Antarctica.

This information is fundamental in the correction of recent model simulations for the MMCO. Even if the environmental magnetic properties of the sediments alone can be a powerful tool to undertand the paleoenvironmental conditions at the time of deposition, further studies are needed to better constrain and quantify the sediment origin, transport and discharge in the basin, as well the paleoceanographic conditions that existed at the time, especially regarding the alternation between oxic and reducing environment, as suggested by the characteristics of the magnetofossils assemblages. 


\section{Chapter 6. Final conclusions and considerations}

Biogenic magnetite, in many sedimentary environments, is one of the most abundant magnetic minerals, and contributes as a carrier of the original magnetic signal. It is also extremely sensitive to variations in the characteristics of the environment during and after the deposition.

In this work, I demonstrated how a comprehensive analysis of the environmental boundary conditions for the preservation of biogenic magnetite in recent sedimentary material offers the possibility to gain indirect indications on oxygen levels during the deposition, from which information about chemical alteration can be obtained.

The selective production and/or preservation of different geometries of biogenic magnetite was demonstrated to be solely related to the availability of oxygen in the pore water, and not by any lithological factors. This results is of great importance as it means that relative abundance of different morphotypes of biogenic magnetite can, in principle, be used as indicators for paleo-oxygen concentration in the pore water, regardless of the sediment origin and characteristics.

This work could be the first step into the creation of a new proxy for paleo-oxygenation of water solely based on magnetic properties. Further work is needed to expand these results. New data from different areas and basins must be collected and possibly coupled with in laboratory experiments in order to expand these findings into fully useful numeric proxies, but the results so far indicate how promising this technique can be. Some points still need to be clarified, such as the possible species-dependent differential production of biogenic magnetite.

The application of these first results led to a more detailed characterization and to a possibly better understanding of two periods of the climatic history of the Earth that are still not fully understood.

> The Baskil section proved to be a continuous, expanded, tecntonically undisturbed sequence with high preservation of micro- and macrofossils, and represents a perfect spot to study in high detail the drastic changes that happened during the Middle Eocene, linked to the closure of the Neo-Tethys Ocean. The MECO period is recorded 
in this section as a period of high accumulation of magnetic minerals, dominated by biogenic magnetite. The magnetofossils are the result of increased Fe content in the water column, which fertilized the ocean. Increased water stratification was inferred from the relative abundance of different morphologies of biogenic magnetite, as the best way to explain low oxygen concentrations during the time.

A secondary finding is the presence of two distinct short-term periods of high accumulation of detrital magnetic minerals. The lower of them can be related to the already known CAE-3 event, while the upper one is still undescribed. This event could be a new event that the high temporal resolution of this section allowed to be recorded in the sediment.

The qualities of the Baskil Section could led to the possible future indication as a candidate for the definition of the GSSP of the Lutetian-Bartonian boundary, once a complete set of chemostratigraphic and cyclostratigraphic data are available.

$>$ The analysis of paleomagnetic data from DSDP Site274 led to the production of more detailed age model for the section than previously available. The sediment collected from the site spans the time interval between the Late Eocene and the Middle Miocene, and records the climatic history and evolution of the Antarctic ice sheet during that period. The results from rock and environmental magnetic data show how periods of warm and cool climate alternated and how they influenced the sedimentation in the basin. Periods of high temperatures led to the partial melting of the ice sheet and the consequent discharge of detritus that had been accumulated, leading to an increase of Fe content in the waters, which in turn enhanced the production of biogenic magnetite by MTB. An unconformity led to the loss of about $7 \mathrm{Myr}$, not permitting to reconstruct a continuous record of the evolution of the area. The data need to be integrated with stable isotope analyses, in order to better quantify and define the characteristics of the diverse climatic events that happened during that period.

\section{References}


Agnini, C., Fornaciari, E., Giusberti, L., Grandesso, P., Lanci, L., Luciani, V., Muttoni, G., Pälike, H., Rio, D., Spofforth, D.J.A., and Stefani, C., 2011, Integrated biomagnetostratigraphy of the Alano section (NE Italy): A proposal for defining the middle-late Eocene boundary: Geological Society of America Bulletin, v. 123, p. 841-872, doi:10.1130/B30158.1.

Agnini, C., Fornaciari, E., Raffi, I., Catanzariti, R., Palike, H., Backman, J., and Rio, D., 2014, Biozonation and biochronology of Paleogene calcareous nannofossils from low and middle latitudes: Newsletters on Stratigraphy, v. 47, p. 131-181, doi:10.1127/0078-0421/2014/0042.

Adams, J. M., Faure, H. F. D. L., Faure-Denard, L., McGlade, J. M., \& Woodward, F. I. (1990). Increases in terrestrial carbon storage from the Last Glacial Maximum to the present. Nature, $348(6303), 711$.

Akgül, B., 1993, Petrographical and Petrological Features of Magmatic Rocks in the Vicinity

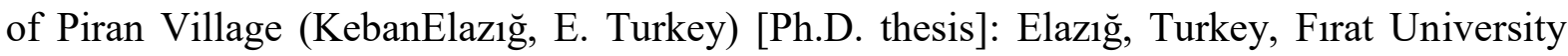
Graduate School of Science and Technology, 128 p. [in Turkish with English abstract].

Akpınar, M.C., 1988, Sedimentological Investigation of the Area of ÇatalharmanÇömlekKurtoğlu Villages (Elazı̆̆ NW) [Master's thesis]: Elazı̆̆g, Turkey, Fırat University Graduate School of Science and Technology, 63 p. [in Turkish with English abstract].

Aksoy, E., 1993, Geological features of the western and southern area of the Elaziğ Basin: Turkish Journal of Earth Sciences, v. 1, no. 1, p. 113-123.

Aksoy, E., Turan, M., Türkmen, İ., and Özkul, M., 1996, Tertiary evolution of the Elazığ Basin, E. Turkey, in Korkmaz, S., and Akçay, M., eds., Proceedings of 30th Anniversary Symposium of Geology Department: Trabzon, Turkey, Karadeniz Technical University, p. 293- 310 [in Turkish with English abstract].

Aksoy, E., Türkmen, İ., and Turan, M., 2005, Tectonics and sedimentation in convergent margin basins: An example from the Paleogene Elazı ̆ Basin, eastern Turkey: Journal of Asian Earth Sciences, v. 25, p. 459-472, doi:10.1016/j.jseaes.2004.04.009.

Aktaş, G., and Robertson, H.F., 1984, The Maden complex, SE Turkey: Evolution of a Neotethyan active margin, in Dixon, J.E., and Robertson, A.H.F., eds., The Geological 
Evolution of the Eastern Mediterranean: Geology Society, London, Special Publication 17, p. 372-402, doi:10.1144/GSL.SP.1984.017.01.27.

Almeida, F.F.M. (1977). O cráton São Francisco. Revista Brasileira de Geociências. 7, 349379 (in portuguese).

Balasubramanian, C., Joseph, B., Gupta, P., Saini, N.L., Mukherjee, S., Di Gioacchino, D., Marcelli, A. (2014). X-ray absorption spectroscopy characterization of iron-oxide nanoparticle synthesized by high temperature plasma processing. J. Electron Spectrosc. Relat. Phenom., $196,125-129$.

Barker, S., \& Knorr, G. (2007). Antarctic climate signature in the Greenland ice core record. Proceedings of the National Academy of Sciences, 104(44), 17278-17282.

Basley, J.R., and Buddington, A.F., 1960, Magnetic susceptibility anisotropy and fabric of some Adirondack granites and orthogneisses: American Journal of Science, v. 258, p. 6-20.

Baumgartner, J., Morin, G., Menguy, N., Gonzales, T.P., Widdrat, M., Cosmidis, J., Faivre, D. (2013). Magnetotactic bacteria form magnetite from a phosphate-rich ferric hydroxide via nanometric ferric (oxyhydr)oxide intermediates. Proc. Natl. Acad. Sci. USA, 110, 1488314888.

Baumgartner, J., Menguy, N., Perez Gonzales, T., Morin, G., Widdrat, M., Faivre, D. (2016). Elongated magnetite nanoparticle formation from a solid ferrous precursor in a magnetotactic bacterium. J. R. Soc. Interface, 13, 20160665, doi:10.1098/rsif2016.0665.

Bazylinski, D. A., B. R. Heywood, S. Mann, and R. B. Frankel. (1993). $\mathrm{Fe}_{3} \mathrm{O}_{4}$ and $\mathrm{Fe}_{3} \mathrm{~S}_{4}$ in a bacterium. Nature, 366, 218.

Bazylinski, D.A., Frankel, R.B., Heywood, R.B., Mann, S., King, J.W., Donaghay, P.L. et al. 1995. Controlled biomineralization of magnetite $\left(\mathrm{Fe}_{3} \mathrm{O}_{4}\right)$ and greigite $\left(\mathrm{Fe}_{3} \mathrm{~S}_{4}\right)$ in a magnetotactic bacterium. Appl, Environ, Microbiol, 61, 3232-3239.

Bazylinski, D.A., Frankel, R.B. (2004(. Magnetosome formation in prokaryotes. Nat. Rev. Microbiol, 2, 217-230.

Bazylinski, D.A. and Williams, T.J., (2006). Ecophysiology of magnetotactic bacteria. 
In Magnetoreception and magnetosomes in bacteria (pp. 37-75). Springer, Berlin, Heidelberg.

Berggren, W.A., and Miller, K.G., 1989, Cenozoic bathyal and abyssal calcareous benthic foraminiferal zonation: Micropaleontology, v. 35, p. 308-320, doi:10.2307/1485674.

Bernardes, R.A., 1996. Estrutura e dinâmica da ictiofauna do Saco do Mamanguá (Paraty-RJ). Universidade de São Paulo (in portuguese).

Benites, M., Pavani, D.A., de los Santos Maly, M., Jovane, L. (2015). Shallow gas occurence in a Brazilian Ría (Saco do Mamangua, Rio de Janeiro), inferred from high-resolution seismic data. Continental Shelf Research. 108, 89-96.

Bijl, P. K., Houben, A. J., Schouten, S., Bohaty, S. M., Sluijs, A., Reichart, G. J., \& Brinkhuis, H. (2010). Transient Middle Eocene atmospheric CO2 and temperature variations. Science, 330(6005), 819-821.

Bingöl, A.F., 1984, Geology of the Elazığ area in the Eastern Taurus region, in Tekeli, O., and Göncüoğlu, C., eds., Geology of the Taurus Belt: Proceedings of International Tauride Symposium: Mineral Research and Exploration Institute of Turkey Publications, p. 209-216 [in Turkish with English abstract].

Bingöl, A.F., and Beyarslan, M., 1996, The geochemistry and petrology of Elazı̆̆ magmatics, in Korkmaz, S., and Akçay, M., eds., Proceedings of 30th Anniversary Symposium of Geology Department: Trabzon, Turkey, Karadeniz Technical University, p. 208-224 [in Turkish with English abstract].

Biscaye, P.E., 1965. Mineralogy and sedimentation of recent deep-sea clay in the Atlantic Ocean and adjacent seas and oceans. Geological Society of America Bulletin, 76(7), pp.803832.

Bloemendal, J., King, J. W., Hall, F. R., \& Doh, S. J. (1992). Rock magnetism of Late Neogene and Pleistocene deep-sea sediments: Relationship to sediment source, diagenetic processes, and sediment lithology. Journal of Geophysical Research: Solid Earth, 97(B4), 4361-4375.

Bohaty, S. M., \& Zachos, J. C. (2003). Significant Southern Ocean warming event in the late middle Eocene. Geology, 31(11), 1017-1020. 
Bohaty, S. M., Zachos, J. C., Florindo, F., \& Delaney, M. L. (2009). Coupled greenhouse warming and deep-sea acidification in the middle Eocene. Paleoceanography, 24(2).

Bohaty, S. M., Zachos, J. C., \& Delaney, M. L. (2012). Foraminiferal Mg/Ca evidence for southern ocean cooling across the eocene-oligocene transition. Earth and Planetary Science Letters, 317, 251-261.

Brookins, D.G., 1988. Eh-pH Diagrams for Geochemistry. Springer-Verlag, Berlin (184 pp.)

Bryden, H. L., J. Candela, and T. H. Kinder (1994), Exchange through the Strait of Gibraltar, Prog. Oceanogr., 33, 201-248.

Butler, R.W.H., and Mazzoli, S., 2006, Styles of continental contraction: A review and introduction, in Mazzoli, S., and Butler, R.W.H., eds., Styles of Continental Contraction: Geological Society of America Special Paper 414, p. 1-10, doi:10.1130/2006.2414(01)

Calgar, M., 2009, Benthic foraminiferal biostratigraphy of the Tertiary sediments from the Elazığ and Malatya Basins, eastern Turkey: Journal of the Geological Society of India, v. 74, p. 209-222, doi:10.1007/ s12594-009-0123-8.

Castaing, P., Guilcher A. (1995). Geomorphology and sedimentology of Rías. In: Perillo, G.M.E. (Ed.). Geomorphology and Sedimentology of Estuaries, 69-111. DOI: 10.1590/S0102$261 \times 2004000100006$

Chang, L., Winklhofer, M., Roberts, A.P., Heslop, D., Florindo, F., Dekkers, M.J., Krijgsman, W., Kodama, K., Yamamoto, Y. (2013). Low-temperature magnetic properties of pelagic carbonates: oxidation of biogenic magnetite and identification of magnetosome chains. $J$.

Geophys. Res., 118, 6049-6065.

Chang, L., Heslop, D., Roberts, A.P., Rey, D., Mohamed, K.J. (2016). Discrimination of biogenic and detrital magnetite through a double Verwey transition temperature. J. Geophys. Res., 121, 3-14.

Chang, S.B.R., Kirschvink, J.L. (1989). Magnetofossils, the magnetization of sediments, and the evolution of magnetite biomineralization. Ann. Rev. Earth Planet. Sci., 17, 169-195. 
Charriau, A., Lesven, L., Gao, Y., Leermakers, M., Baeyens, W., Ouddane, B., and Billon, G. 2011.Trace metal behaviour in riverine sediments: Role of organic matter and sulfides. App. Geochem. 26, 80-90.

Chen, A.P., Berounsky, V.M., Chan, M.K., Blackford, M.G., Cady, C., Moskowitz, B.M., Kraal, P., Lima, E.A., Kopp, R.E., Lumpkin, G.R. and Weiss, B.P., 2014. Magnetic properties of uncultivated magnetotactic bacteria and their contribution to a stratified estuary iron cycle. Nature communications, 5, p.4797.

Chung, F.H., (1974). Quantitative interpretation of X-ray diffraction patterns of mixtures. II. Adiabatic principle of X-ray diffraction analysis of mixtures. Journal of Applied Crystallography, 7(6), pp.526-531.

Cotton, L.J., Pearson, P.N., and Renema, W., 2015, A new Eocene lineage of reticulate Nummulites (foraminifera) from Kilwa District, Tanzania; a place for Nummulites ptukhiani?: Journal of Systematic Palaeontology, v. 14, no. 7, p. 569-579, doi:10.1080/14772019.2015.1079562

Cotton, L.J., Zakrevskaya, E.Y., van der Boon, A., Asatryan, G., Hayrapetyan, F., Israelyan, A., Krijgsman, W., Less, G., Monechi, S., Papazzoni, C.A., Pearson, P.N., Razumovskiy, A., Renema, W., Shcherbinina, E., and Wade, B., 2016, Integrated stratigraphy of the Priabonian (Upper Eocene) Urtsadzor section, Armenia: Newsletters on Stratigraphy, v. 50, no. 3, p. 265295, doi:10.1127/nos/2016/0313.

Coxall, H. K., Wilson, P. A., Pälike, H., Lear, C. H., \& Backman, J. (2005). Rapid stepwise onset of Antarctic glaciation and deeper calcite compensation in the Pacific Ocean. Nature, 433(7021), 53.

Drooger, C.W., 1993, Radial foraminifera; morphometrics and evolution: Verhandelingen der Koninklijke Nederlandse Akademie van Wetenschappen: Afdeling Natuurkunde, v. 41, p. 124

Dunin-Borkowski, R.E., McCartney, M.R., Frankel, R.B., Bazylinski, D.A., Pósfai, M., Buseck, P.R. (1998). Magnetic microstructure of magnetotactic bacteria by electron holography. Science, 282, 1868-1870. 
Dunlop, D.J., 1979, On the use of Zjiderveld vector diagrams in multicomponent paleomagnetic studies: Physics of the Earth and Planetary Interiors, v. 20, p. 12-24, doi:10.1016/0031-9201(79)90103-1

Dunlop, D. J. \& Özdemir, Ö. 1997. Rock Magnetism. Fundamentals and Frontiers. Cambridge Studies in Magnetism Series. xxi 573 pp. Cambridge, New York

Edgar, K. M., Wilson, P. A., Sexton, P. F., Gibbs, S. J., Roberts, A. P., \& Norris, R. D. (2010). New biostratigraphic, magnetostratigraphic and isotopic insights into the Middle Eocene Climatic Optimum in low latitudes. Palaeogeography, Palaeoclimatology, Palaeoecology, 297(3-4), 670-682.

Egli, R. 2004a. Characterization of individual rock magnetic components by analysis of remanence curves. Physics and Chemistry of the Earth, 13 (29), 851-867.

Egli, R. 2004b. Characterization of individual rock magnetic components by analysis of remanence curves: 2. Fundamental properties of coercivity distribution. Physics and Chemistry of the Earth, 29 (13-14), 851-867.

Egli, R. 2004c. Characterization of individual rock magnetic components by analysis of remanence curves: 3. Bacterial magnetite and natural processes in lakes. Physics and Chemistry of the Earth, 29, 867-884.

Egli, R., Chen, A.P., Winklhofer, M., Kodama, K.P. and Horng, C.S., 2010. Detection of noninteracting single domain particles using first-order reversal curve diagrams. Geochemistry, Geophysics, Geosystems, 11(1).

Evans, M., \& Heller, F. (2003). Environmental magnetism: principles and applications of enviromagnetics (Vol. 86). Academic press.

Exon, N. F., Brinkhuis, H., Robert, C. M., Kennett, J. P., Hill, P. J., \& Macphail, M. K. (2004). Tectono-Sedimentary History of Uppermost Cretaceous Through Oligocene Sequences from the Tasmanian Region: A Temperate Antarctic Margin. The Cenozoic Southern Ocean: Tectonics, Sedimentation, and Climate Change Between Australia and Antarctica, 319-344. 
Fdez-Gubieda, M.L., Muela, A., Alonso, J., Garcia-Prieto, A., Olivi, L., Fernandez-Pacheco, R., Barandiaran, J.M. (2013). Magnetite biomineralization in Magnetospirillum gryphiswaldense: time-resolved magnetic and structural studies. ACS Nano, 7, 3297-3305.

Flower, B. P., \& Kennett, J. P. (1993). Middle Miocene ocean-climate transition: Highresolution oxygen and carbon isotopic records from Deep Sea Drilling Project Site 588A, southwest Pacific. Paleoceanography, 8(6), 811-843.

Fornaciari, E., Agnini, C., Catanzariti, R., Rio, D., Bolla, E.M., and Valvasoni, E., 2010, Midlatitude calcareous nannofossil biostratigraphy and biochronology across the middle to late Eocene transition: Stratigraphy, v. 7, no. 4, p. 229-264.

Frank, U., \& Nowaczyk, N. R. (2008). Mineral magnetic properties of artificial samples systematically mixed from haematite and magnetite. Geophysical Journal

International, 175(2), 449-461.

Galazzo, F. B., Giusberti, L., Luciani, V., \& Thomas, E. (2013). Paleoenvironmental changes during the Middle Eocene Climatic Optimum (MECO) and its aftermath: the benthic foraminiferal record from the Alano section (NE Italy). Palaeogeography, Palaeoclimatology, Palaeoecology, 378, 22-35.

Galeotti, S., DeConto, R., Naish, T., Stocchi, P., Florindo, F., Pagani, M., Barrett, P., Bohaty, S.M., Lanci, L., Pollard, D. and Sandroni, S., (2016). Antarctic Ice Sheet variability across the Eocene-Oligocene boundary climate transition. Science, p.aab0669.

Garrels, R.M., Christ, C.L., 1965. Solutions, Minerals, and Equilibria. Harper and Row, New York (450 pp.).

Gilder, S., Chen, Y., and Sen, S., 2001, Oligo-Miocene magnetostratigraphy and rock magnetism of the Xishigou section, Subei (Gansu Province, western China) and implications for shallow inclinations in Central Asia: Journal of Geophysical Research, v. 106, p. 30,50530,521, doi:10.1029/2001JB000325.

Gradstein, F.M., Ogg, J.G., Schmitz, M.D., Ogg, G.M. 2012. The geologic Time Scale 2012. Elsvier publications. 
Graham, J.B., and Hamilton, T., 2004, Magnetic fabrics may proxy as neotectonic stress trajectories, Polis rift, Cyprus: Tectonics, v. 23, p. TC1001, doi:10 .1029/2002TC001434.

Hamilton, N., and Rees, A.I., 1970, The use of magnetic fabric in palaeocurrent estimation, in Runcorn, S.K., ed., Palaeogeophysics: London, Academic Press, p. 445-464.

Harrison,R. J., and J. M. Feinberg (2008), FORCinel: An improved algorithm for calculating first-order reversal curve distributions using locally weighted regression smoothing, Geochem. Geophys. Geosyst., 9, Q05016, doi:10.1029/2008GC001987.

Herold, N., You, Y., Müller, R. D., \& Seton, M. (2009). Climate model sensitivity to changes in Miocene paleotopography. Australian Journal of Earth Sciences, 56(8), 1049-1059.

Heslop, D., Dekkers, M.J., Kruiver, P.P., van Oorschot, I.H.M. (2002). Analysis of isothermal remanent magnetization acquisition curves using the expectation-maximization algorithm.

Geophys. J. Int., 148, 58-64.

Heslop, D., Roberts, A.P., Chang, L., Davies, M., Abrajevitch, A. and De Deckker, P., 2013. Quantifying magnetite magnetofossil contributions to sedimentary magnetizations. Earth and Planetary Science Letters, 382, pp.58-65.

Hesse, P.P. 1994. Evidence for bacterial paleoecological origin of mineral magnetic cycles in oxic and sub-oxic Tasman sea sediments. Marine Geology. 117, 1-17.

Heward, A.P., 1978, Alluvial fan and lacustrine sediments from the Stephanian A and B (La Magdalena, CineraMatallana and Sabero) coalfields, northern Spain: Sedimentology, v. 25, p. 451-488.

Hillier, S., Roe, M.J., Geelhoed, J.S., Fraser, A.R., Farmer, J.G. and Paterson, E., 2003. Role of quantitative mineralogical analysis in the investigation of sites contaminated by chromite ore processing residue. Science of the Total Environment, 308(1-3), pp.195-210.

Hrouda, F., 1982, Magnetic anisotropy of rocks and its application in geology and geophysics: Geophysical Surveys, v. 5, p. 37-82, doi:10.1007/BF01450244

Housen, B. A., \& Moskowitz, B. M. (2006). Depth distribution of magnetofossils in nearsurface sediments from the Blake/Bahama Outer Ridge, western North Atlantic Ocean, 
determined by low-temperature magnetism. Journal of Geophysical Research: Biogeosciences, 111(G1).

Houtz, R., \& Meijer, R. (1970). Structure of the Ross Sea shelf from profiler data. Journal of geophysical research, 75(32), 6592-6597.

İnceöz, M., 1994, Geological Features of the Northern and Eastern Vicinities of Harput (Elazığ) [Ph.D. thesis]: Elazığ, Turkey, Frrat University Graduate School of Science and Technology, $112 \mathrm{p}$

Karami, M. P., De Leeuw, A., Krijgsman, W., Meijer, P. T., \& Wortel, M. J. R. (2011). The role of gateways in the evolution of temperature and salinity of semi-enclosed basins: An oceanic box model for the Miocene Mediterranean Sea and Paratethys. Global and Planetary Change, 79(1-2), 73-88.

Kirschvink, J. L. (1980). The last-squares line and plane analysis of paleomagnetic data. Geophysical Journal of the Royal Astronomical Society. 62, 699-710.

Kopp, R.E. and Kirschvink, J.L. 2008. The identification and biogeochemical interpretation of fossil magnetotactic bacteria. Earth-Science Reviews. 86, 42-61.

Kruiver, P. P., Dekkers, M. J., \& Heslop, D. (2001). Quantification of magnetic coercivity components by the analysis of acquisition curves of isothermal remanent magnetisation. Earth and Planetary Science Letters, 189(3-4), 269-276.

Kürschner, W. M., Kvaček, Z., \& Dilcher, D. L. (2008). The impact of Miocene atmospheric carbon dioxide fluctuations on climate and the evolution of terrestrial ecosystems. Proceedings of the National Academy of Sciences, 105(2), 449-453.

Jickells, T.D., An, Z.S., Andersen, K.K., Baker, A.R., Bergametti, G., Brooks, N., Cao, J.J., Boyd, P.W., Duce, R.A., Hunter, K.A. and Kawahata, H., 2005. Global iron connections between desert dust, ocean biogeochemistry, and climate. science, 308(5718), pp.67-71

Joseph, B., Iadeloca, A., Simonelli, L., Mizuguchi, Y., Takano, Y., Mizokawa, T., Saini, N.L. (2010). A study of the electronic structure of $\mathrm{FeSe}_{1-} x$ Tex chalcogenides by Fe and Se K-edge 
X-ray absorption edge structure measurements. J. Phys.: Condens. Matter, 22, 485702, doi:10.1088/0953-8984/22/48/485702.

Jovane, L., Florindo, F., Coccioni, R., Dinarès-Turell, J., Marsili, A., Monechi, S., ... \& Sprovieri, M. (2007). The middle Eocene climatic optimum event in the Contessa Highway section, Umbrian Apennines, Italy. Geological Society of America Bulletin, 119(3-4), 413427.

Jovane, L., Acton, G., Florindo, F., \& Verosub, K. L. (2008). Geomagnetic field behavior at high latitudes from a paleomagnetic record from Eltanin core 27-21 in the Ross Sea sector, Antarctica. Earth and Planetary Science Letters, 267(3-4), 435-443.

Jovane, L., Coccioni, R., Marsili, A., and Acton, G., 2009, The late Eocene greenhouseicehouse transition: Observations from Massignano global stratotype section and point (GSSP), in Koeberl, C., and Montanari, A., eds., The Late Eocene Earth-Hothouse, Icehouse, and Impacts: Geological Society of America Special Paper 452, p. 149-168, doi:10.1130/2009.2452(10).

Jovane, L., Sprovieri, M., Coccioni, R., Florindo, F., Marsili, A., \& Laskar, J. (2010). Astronomical calibration of the middle Eocene Contessa Highway section (Gubbio, Italy). Earth and Planetary Science Letters, 298(1-2), 77-88.

Jovane, L., Yokoyama, E., Seda, T., Burmester, R.F., Trindade, R.I.F., Housen, B.A. (2011). Rock magnetism of hematitic "bombs" from the Araguainha impact structure, Brazil. Geochemistry, Geophysics, Geosystems. 12, Q12Z34, doi:10.1029/2011GC003758.

Jovane, L., Florindo, F., Bazylinski, D.A. and Lins, U., (2012). Prismatic magnetite magnetosomes from cultivated Magnetovibrio blakemorei strain MV-1: a magnetic fingerprint in marine sediments?. Environmental microbiology reports, 4(6), pp.664-668.

Jovane, L., Herrero-Bervera, E., Hinnov, L. A. \& Housen, B. A. (2013). (eds) Magnetic Methods and the Timing of Geological Processes. Geological Society, London, Special Publications, 373.

Ladant, J. B., Donnadieu, Y., Lefebvre, V., \& Dumas, C. (2014). The respective role of atmospheric carbon dioxide and orbital parameters on ice sheet evolution at the EoceneOligocene transition. Paleoceanography, 29(8), 810-823. 
Larrasoana, J. C., Roberts, A. P., Chang, L., Schellenberg, S. A., Gerald, J. D. F., Norris, R. D., \& Zachos, J. C. (2012). Magnetotactic bacterial response to Antarctic dust supply during the Palaeocene-Eocene thermal maximum. Earth and Planetary Science Letters, 333, 122133.

Lascu, I., Harrison, R. J., Li, Y. T., Muraszko, J. R., Channell, J. E. T., Piotrowsky, Moskowitz, B.M., Bazylinski, D.A., Egli, R., Frankel, R.B., Edwards, K.J. (2008). Magnetic properties of marine magnetotactic bacteria in a seasonally stratified coastal pond (Salt Pond, MA, USA). Geophys. J. Int., 174, 75-92.

Lascu, I., Harrison, R.J., Li, Y., Muraszko, J.R., CHannell, J.E.T., Piotrowski, A. M. and Hodell, D. A., 2015, Magnetic Unmixing of First-Order Reversal Curve Diagrams using Principal Component Analysis. Geochemistry, Geophysics, Geosystems

16, doi: 10.1002/2015GC005909.

Lear, C. H., Bailey, T. R., Pearson, P. N., Coxall, H. K., \& Rosenthal, Y. (2008). Cooling and ice growth across the Eocene-Oligocene transition. Geology, 36(3), 251-254.

Lirer, F., 2000, A new technique for retrieving calcareous microfossils from lithified lime deposits: Micropaleontology, v. 46, p. 365-369

Less, Gy., Özcan, E., Papazzoni, C.A., and Stockar, R., 2008, The middle to late Eocene evolution of nummulitid foraminifer Heterostegina in the Western Tethys: Acta Palaeontologica Polonica, v. 53, p. 317-350, doi:10.4202/ app.2008.0212.

Less, Gy., and Özcan, E., 2012, Bartonian-Priabonian larger benthic foraminiferal events in the Western Tethys: Mitteilungen der Österreichischen Geologischen Gesellschaft, v. 105, no. 1, p. 129-140.

Liu, Z., Pagani, M., Zinniker, D., DeConto, R., Huber, M., Brinkhuis, H., Shah, S.R., Leckie, R.M. and Pearson, A., 2009. Global cooling during the Eocene-Oligocene climate transition. Science, 323(5918), pp.1187-1190.

Liu, Y., Li., G.R., Guo, F.F., Li, Y., Li., L.J. (2010) Large-scale production of magnetosomes by chemostat culture of Magnetospirillum gryphiswaldense at high cell density. Microbial Cell Factories. 9, 99. DOI: 10.1186/1475-2859-9-99 
Liu, Q.S., Roberts, A.P., Larrasoaña, J.C., Banerjee, S.K., Guyodo, Y., Tauxe, L., Oldfield, F. (2012). Environmental magnetism: principles and applications. Rev. Geophys. 50, RG4002. http://dx.doi.org/10.1029/2012RG000393.

Lewis, A. R., Marchant, D. R., Ashworth, A. C., Hemming, S. R., \& Machlus, M. L. (2007). Major middle Miocene global climate change: Evidence from East Antarctica and the Transantarctic Mountains. Geological Society of America Bulletin, 119(11-12), 1449-1461.

Lurcock, P.C., and Wilson, G.S., 2012, PuffinPlot: A versatile, user-friendly program for paleomagnetic analysis: Geochemistry Geophysics Geosystems, v. 13, p. Q06Z45, doi:10.1029/2012GC004098

Lyle, M., Olivarez Lyle, A., Backman, J. \& Tripati, A. (2005). Biogenic sedimentation in the Eocene equatorial Pacific-The stuttering greenhouse and Eocene carbonate compensation depth. Proc. ODP Sci. Res. (eds Wilson, P. A., Lyle, M. \& Firth, J. V.) 199, 1-35 Mann, S., Frankel, R.B. and Blakemore, R.P., 1984. Structure, morphology and crystal growth of bacterial magnetite. Nature, 310(5976), p.405.

Martin, J.H. and Fitzwater, S.E., 1988. Iron deficiency limits phytoplankton growth in the north-east Pacific subarctic. Nature, 331(6154), p.341.

Martini, E., 1971, Standard Tertiary and Quaternary calcareous nannoplankton zonation, in Farinacci, A., ed., Proceedings of the 2nd Planktonic Conference, Volume 2: Roma, Edizioni Technoscienza, p. 739-785

McFadden, P. L., Lowes, F.J. 1981. The discrimination of mean direction drawn from Fisher distribution. Geophys. J. R. astr. Soc. 67, 19-33.

Miller, K. G., Wright, J. D., \& Fairbanks, R. G. (1991). Unlocking the ice house: OligoceneMiocene oxygen isotopes, eustasy, and margin erosion. Journal of Geophysical Research:

Solid Earth, 96(B4), 6829-6848.

Miller, Kenneth G., Michelle A. Kominz, James V. Browning, James D. Wright, Gregory S. Mountain, Miriam E. Katz, Peter J. Sugarman, Benjamin S. Cramer, Nicholas Christie-Blick, 
and Stephen F. Pekar. (2005) The Phanerozoic record of global sea-level change.Science 310, 5752 1293-1298.

Morillo, V., Abreu, F., Araujo, A.C., de Almeida, L.G.P., Enrich-Prast, A., Farina, M., de Vasconcelos, A.T.R., Bazylinski, D., Lins, U. 2014. Isolation, cultivation and genomic analysis of magnetosome biomineralization genes of a new genus of south-seeking magnetotactic cocci within the Alphaproteobacteria. Front. Microbiology., 5, doi:10.3389/2014.00072.

Moore, D.M. and Reynolds, R.C., 1989. X-ray Diffraction and the Identification and Analysis of Clay Minerals (Vol. 332). New York: Oxford university press.

Morse, J.W. and Luther, G. 1999. Chemical influences on trace metal-sulfide interactions in anoxic sediments. Geochimica et Cosmochimica Acta. 63. 3373-3378. Doi:10.1016/S00167037(99)00258-6.

Moskowitz, B. 1993. Micromagnetic Study of the Influence of Crystal Defects on Coercivity in Magnetite. Journal of Geophysical Research. 98, 18011-18026.

Okada, H., and Bukry, D., 1980, Supplementary modification and introduction of code numbers of the lowlatitude coccolith biostratigraphic zonation (Bukry 1973, 1975): Marine Micropaleontology, v. 5, p. 321-325, doi:10.1016/0377-8398(80)90016-X.

Oldfield, F. (1991), Environmental magnetism-A personal perspective, Quat. Sci. Rev., 10, 73-85, doi:10.1016/0277-3791(91)90031-O.

Ozima, M., Larson, E. E. (1970). Low- and high-temperature oxidation of titanomagnetite in relation to irreversible changes in the magnetic properties of submarine basalts. J. Geophys. Res. 75 (5), 103-101

Özcan, E., Less, G., Báldi-Beke, M., Kollányi, K., and Kertesz, B., 2006, Biometric analysis of middle and upper Eocene Discocyclinidae and Orbitoclypeidae (Foraminifera) from Turkey and updated orthophragmine zonation in the Western Tethys: Micropaleontology, v. 52, p. 485-520, doi:10.2113/gsmicropal.52.6.485. 
Özkul, M., 1988, Sedimentological Investigations on the Kırkgeçit Formation in the Western Elazığ [Ph.D. thesis]: Elazığg, Turkey, Firat University Graduate School of Science and Technology, 186 p. [in Turkish with English abstract].

Özkul, M., and Kerey, İ.E., 1996, Facies analysis on deep sea, shelf complex: Kırkgeçit Formation (Middle Eocene-Oligocene), Baskil-Elazığ: Turkish Journal of Earth Sciences, v. 5, p. 57-70 [in Turkish with English abstract].

Pagani, M., Arthur, M. A., \& Freeman, K. H. (1999). Miocene evolution of atmospheric carbon dioxide. Paleoceanography, 14(3), 273-292.

Papazzoni, C.A., Cosovic, V., Briguglio, A., and Drobne, K., 2017, Towards a calibrated larger foraminifera biostratigraphic zonation: Celebrating 18 years of the application of shallow benthic zones: Palaios, v. 32, p. 1-5, doi:10.2110/palo.2016.043.

Pearson, P. N., \& Palmer, M. R. (2000). Atmospheric carbon dioxide concentrations over the past 60 million years. Nature, 406(6797), 695.

Pearson, P.N., Nicholas, C.J., Singano, J.M., Bown, P.R., Coxall, H.K., van Dongen, B.E., Huber, B.T., Karega, A., Lees, J.A., MacLeod, K., McMillan, I.K., Pancost, R.D., Pearson, M., and Msaky, E., 2006, Further Paleogene and Cretaceous sediment cores from the Kilwa area of coastal Tanzania: Tanzania Drilling Project Sites 6-10: Journal of African Earth Sciences, v. 45, p. 279-317, doi:10.1016/j.jafrearsci.2006.02.005.

Pan, Y.X., Petersen, N., Winklhofer, M., Davila, A.F., Liu, Q.S., Frederichs, T., Hanzlik, M., Zhu, R.X. (2005). Rock magnetic properties of uncultured magnetotactic bacteria. Earth Planet. Sci. Lett., 237, 311-325.

Pérez-Guzmán, L., Bogner, K.R., Lower, B.H., 2010. Earth's ferrous wheel. Nat. Educ. 3, 32.

Pedrosa-Soares, A.C., Noce, C. M., de Alkmin, F.F., da Silva, L.C., Bambinski, M., Cordani, U., Castañeda, C. (2007). Orógeno Araçuaí: Síntese do conhecimento 30 anos após Almeida 1977. Geonomos. 15 (1), 1-16. 
Pike, C. R., Roberts, A. P., \& Verosub, K. L. (1999). Characterizing interactions in fine magnetic particle systems using first order reversal curves. Journal of Applied Physics, 85(9), 6660-6667.

Pike, C. R., Roberts, A. P., \& Verosub, K. L. (2001). First order reversal curve diagrams and thermal relaxation effects in magnetic particles. Geophysical Journal International, 145(3), 721-730.

Poubaix, M. and de Zubov, N. 1963. Altus d'equilibres eletroquimiques. Gauthier-Villars and Cie, Paris (Poubaix Eds.).

Popa, R., Fang, W., Nealson, K.H., Souza-Egipsy, V., Berquo, T.S., Banerjee, S.K., Penn, L.R. (2009). Effect of oxidative stress on the growth of magnetic particles in Magnetospirillum magneticum. Int. Microbiol., 12, 49-57.

Pourbaix, M., 1974. Atlas of Electrochemical Equilibria in Aqueous Solutions. 2nd English Ed. National Association of Corrosion Engineers, Houston, Texas.

Rego, E. S., Jovane, L., Hein, J. R., Sant'Anna, L. G., Giorgioni, M., Rodelli, D., \& Özcan, E. (2018). Mineralogical evidence for warm and dry climatic conditions in the Neo-Tethys (eastern Turkey) during the middle Eocene. Palaeogeography, Palaeoclimatology, Palaeoecology, 501, 45-57.

Reuter, J., Stott, L., Khider, D., Sinha, A., Cheng, H., \& Edwards, R. L. (2009). A new perspective on the hydroclimate variability in northern South America during the Little Ice Age. Geophysical Research Letters, 36(21).

Roberts, A. P., Pike, C. R., \& Verosub, K. L. (2000). First-order reversal curve diagrams: A new tool for characterizing the magnetic properties of natural samples. Journal of Geophysical Research: Solid Earth, 105(B12), 28461-28475.

Roberts, A.P., Florindo, F., Villa, G., Chang, L., Jovane, L., Bohaty, S.M., Larrasoaña, J.C., Heslop, D. and Gerald, J.D.F., (2011). Magnetotactic bacterial abundance in pelagic marine environments is limited by organic carbon flux and availability of dissolved iron. Earth and Planetary Science Letters, 310(3), pp.441-452. 
Roberts, A.P., Chang, L., Heslop, D., Florindo, F. and Larrasoaña, J.C., (2012). Searching for single domain magnetite in the "pseudo-single-domain" sedimentary haystack: implications of biogenic magnetite preservation for sediment magnetism and relative paleointensity determinations. Journal of Geophysical Research: Solid Earth, 117(B8).

Roberts, A. P., Sagnotti, L., Florindo, F., Bohaty, S. M., Verosub, K. L., Wilson, G. S., \& Zachos, J. C. (2013). Environmental magnetic record of paleoclimate, unroofing of the Transantarctic Mountains, and volcanism in late Eocene to early Miocene glaci-marine sediments from the Victoria Land Basin, Ross Sea, Antarctica. Journal of Geophysical Research: Solid Earth, 118(5), 1845-1861.

Roberts, A.P., (2015). Magnetic mineral diagenesis. Earth-science reviews, 151, pp.1-47. Robertson, D. J., \& France, D. E. (1994). Discrimination of remanence-carrying minerals in mixtures, using isothermal remanent magnetisation acquisition curves. Physics of the Earth and Planetary interiors, 82(3-4), 223-234.

Robertson, A.H.F., Parlak, O., Rízaogb Lu, T., Ünlügenç, Ü., İnan, N., Taşlı, K., and Ustaömer, T., 2007, Tectonic evolution of the South Tethyan ocean: Evidence from the Eastern Taurus Mountains (Elazığ region, SE Turkey), in Ries, A.C., Butler, R.W.H., and Graham, R.H., eds., Deformation of the Continental Crust: The Legacy of Mike Coward: Geological Society, London, Special Publication 272, p. 231-270

Rochette, P., Jackson, M., and Aubourg, C., 1992, Rock magnetism and the interpretation of anisotropy of magnetic susceptibility: Reviews of Geophysics, v. 30, p. 209- 226, doi:10.1029/92RG00733

Savian, J.F., Jovane, L., Boathy, S.M., and Wilson, P.A., 2013, Middle Eocene to early Oligocene magnetostratigraphy of ODP Hole 711A (Leg 115), western equatorial Indian Ocean, in Jovane, L., Herrero-Bervera, E., Hinnov, L.A., and Housen, B., eds., Magnetic Methods and the Timing of Geological Processes: Geological Society, London, Special Publication 371, p. 97-11.

Savian, J.F., Jovane, L., Frontalini, F., Trindade, R.I., Coccioni, R., Bohaty, S.M., Wilson, P.A., Florindo, F., Roberts, A.P., Catanzariti, R. and Iacoviello, F., 2014. Enhanced primary 
productivity and magnetotactic bacterial production in response to middle Eocene warming in the Neo-Tethys Ocean. Palaeogeography, Palaeoclimatology, Palaeoecology, 414, pp.32-45.

Savian, J.F., Jovane, L., Giorgioni, M., Iacoviello, F., Rodelli, D., Roberts, A.P., Chang, L., Florindo, F. and Sprovieri, M., 2016. Environmental magnetic implications of magnetofossil occurrence during the Middle Eocene Climatic Optimum (MECO) in pelagic sediments from the equatorial Indian Ocean. Palaeogeography, Palaeoclimatology, Palaeoecology, 441, pp.212-222.

Savin, S. M., Douglas, R. G., \& Stehli, F. G. (1975). Tertiary marine paleotemperatures. Geological Society of America Bulletin, 86(11), 1499-1510.

Şengör, A.M.C., and Yılmaz, Y., 1981, Tethyan evolution of Turkey: A plate tectonic approach: Tectonophysics, v. 75, p. 181-241, doi:10.1016/0040-1951(81)90275-4.

Şengör, A.M.C., Özeren, M.S., Keskin, M., Sakınç, M., Özbakır, A.D., and Kayan, İ., 2008, Eastern Turkish high plateau as a small Turkic-type orogen: Implications for post-collisional crust-forming processes in Turkic-type orogens: Earth-Science Reviews, v. 90, p. 1-48, doi:10.1016/j.earscirev.2008.05.002.

Seeberg-Elverfeldt, Jens; Schlüter, Michael; Feseker, Tomas; Kölling, Martin (2005): Pore water chemistry of samples near the sediment-water interface. PANGAEA, https://doi.org/10.1594/PANGAEA.738239, Supplement to: Seeberg-Elverfeldt, J et al. (2005): Rhizon sampling of pore waters near the sediment/water interface of aquatic systems. Limnology and Oceanography: Methods, 3, 361-371, https://doi.org/10.4319/lom.2005.3.361

Serra-Kiel, J., Hottinger, L., Caus, E., Drobne, K., Ferrández, C., Jauhri, A.K., Less, Gy., Pavlovec, R., Pignatti, J., Samso, J.M., Schaub, H., Sirel, E., Strougo, A., Tambareau, Y., Tosquella, J., and Zakrevskaya, E., 1998, Larger foraminiferal biostratigraphy of the Tethyan Paleocene and Eocene: Bulletin de la Société Géologique de France, v. 169, p. 281-299

Shackleton, N., Kennett, J.P., 1976. Paleotemperature history of the Cenozoic and the Initiation of Antarctic Glaciation: Oxygen and Carbon Isotope Analyses in DSDP Sites 277, 279, and 281, in: Kennett, J.P.P., Houtz, R.E., et al. (Eds), Initial Reports of the Deep Sea Drilling Project, Vol. XXIX, Washington, D.C. (U.S. Government Printing Office), pp. 743-755. 
Shevenell, A. E., Kennett, J. P., \& Lea, D. W. (2004). Middle Miocene southern ocean cooling and Antarctic cryosphere expansion. Science, 305(5691), 1766-1770.

Sigman, D.M. and Hain, M.P., 2012. The biological productivity of the ocean. Nature Education Knowledge, 3(10), p.21.

Sluijs, A., Zeebe, R. E., Bijl, P. K., \& Bohaty, S. M. (2013). A middle Eocene carbon cycle conundrum. Nature Geoscience, 6(6), 429.

Spera, A., 2012. Registro de variações ambientais dos últimos 3000 anos da Região da Ria do Mamanguá, Rio de Janeiro, utilizando marcadores orgânicos moleculares.Universidade de São Paulo.

Stacey, F.D., Joplin, G., and Linsday, J., 1960, Magnetic anisotropy and fabric of some foliated rocks from SE Australia: Geophysica Pura e Applicata, v. 47, p. 30- 40, doi:10.1007/BF01992481.

Stumm, W., Morgan, J.J., 1996. Aquatic Chemistry: Chemical Equilibria and Rates in Natural Waters. 3rd Ed. John Wiley \& Sons, New York (1022 pp.).

Suganuma, Y., Yamazaki, T., \& Kanamatsu, T. (2009). South Asian monsoon variability during the past 800 kyr revealed by rock magnetic proxies. Quaternary Science Reviews, 28(910), 926-938

Sungurlu, O., Perinçek, D., Kurt, G., Tuna, E., Dülger, S., Çelikdemir, E., and Naz, H., 1985, Geology of the Elazığ-Hazar-Palu area: The Bulletin of Turkish Association of Petroleum Geologists, v. 29, p. 83-191

Super, J.R., Thomas, E., Pagani, M., Huber, M., O’Brien, C., Hull, P.M. 2018. North Atlantic temperature and $\mathrm{pCO}_{2}$ coupling in the early-middle Miocene. Geology, 46(6), 519-522.

Tarduno, J. A., Brinkman, D. B., Renne, P. R., Cottrell, R. D., Scher, H., \& Castillo, P. (1998). Evidence for extreme climatic warmth from Late Cretaceous Arctic vertebrates. Science, 282(5397), 2241-2243.

Tatar, Y., 1987, Tectonic structure of the Elazığ area and some observations on Landsat images: Bulletin of Earth Sciences Application and Research Centre of Hacettepe University, 
v. 14, p. 295-308 [in Turkish with English abstract]

Teixeira, C.L., 2009. Caracterização do sedimento superficial de enseadas da Baía da Ilha Grande-RJ, com ênfase na distribuição espacial de metais. Universidade Federal Fluminese. (in Portuguese).

Thompson, R., J. Bloemendal, J. A. Dearing, F. Oldfield, T. A. Rummery, J. A. Stober, and G. M. Turner (1980), Environmental applications of magnetic measurements, Science, 207, 481486, doi:10.1126/science.207.4430.481.

Thompson, R., and F. Oldfield (1986), Environmental Magnetism, Allen and Unwin, Winchester, Mass., doi:10.1007/978-94-011-8036-8

Tripati, A., Backman, J., Elderfield, H., \& Ferretti, P. (2005). Eocene bipolar glaciation associated with global carbon cycle changes. Nature, 436(7049), 341.

Turan, M., 1984, The Stratigraphy and Tectonics of BaskilAydınlar (West of Elazı̆̆, E. Turkey) Area [Ph.D. thesis]: Elazığ, Turkey, Firat University Graduate School of Science and Technology, 180 p. [in Turkish with English abstract].

Turan, M., and Bingöl, A.F., 1991, Tectono-stratigraphic characteristics of the region between Kovancılar-Baskil (east of Elazı̆̆g, E. Turkey), in Yetiş, C., ed., Proceedings of Ahmet Acar Symposium: Adana, Turkey, Çukurova University, p. 193-204 [in Turkish with English abstract]

Turan, M., and Türkmen, İ., 1996, Stratigraphy and sedimentological features of Kuşçular Formation (Lower Paleocene): Turkish Journal of Earth Sciences, v. 5, p. 109-121 [in Turkish with English abstract].

Turan, M., Aksoy, E., and Bingöl, A.F., 1995, Characteristics of the geodynamic evolution of Eastern Taurus in the Elazığ region: Journal of Frrat University: Science and Technology, v. 7, no. 2, p. 177-199 [in Turkish with English Abstract].

Türkmen, İ., 1991, Stratigraphy and sedimentological features of Çaybağı Formation (Upper Miocene-Pliocene) in the eastern Elazığ: Bulletin of the Turkish Geological Society, v. 34, no. 1, p. 45-53 [in Turkish with English abstract]. 
Türkmen, İ., İnceöz, M., and Kerey, İ.E., 1999, Kırkgeçit Formation (middle EoceneOligocene): An example of tidal flat and stormy shelf complex (NNW of Elazığ): Bulletin of Earth Sciences Application and Research Centre of Hacettepe University, v. 21, p. 125-142 [in Turkish with English abstract].

Türkmen, İ., İnceöz, M., Aksoy, E., and Kaya, M., 2001, New findings on Eocene stratigraphy and paleogeography of Elazığ area: Bulletin of Earth Sciences Application and Research Centre of Hacettepe University, v. 24, p. 81-95 [in Turkish with English abstract].

van Morkhoven, F.P.C.M., and Edwards, A.S., 1986, Cenozoic Cosmopolitan Deep-Water Benthic Foraminifera: Elf-Aquitaine Mémoire 11, 423 p

von der Heydt, A., \& Dijkstra, H. A. (2006). Effect of ocean gateways on the global ocean circulation in the late Oligocene and early Miocene. Paleoceanography, 21(1).

Verosub, K.L., Roberts, A.P., 1995. Environmental magnetism: past, present, and future. J. Geophys. Res. 100, 2175-2192. http://dx.doi.org/10.1029/94JB02713.

Villa, G., Lupi, C., Cobianchi, M., Florindo, F., \& Pekar, S. F. (2008). A Pleistocene warming event at $1 \mathrm{Ma}$ in Prydz Bay, East Antarctica: evidence from ODP site 1165. Palaeogeography, Palaeoclimatology, Palaeoecology, 260(1), 230-244.

Vincent, E., \& Berger, W. H. (1985). Carbon dioxide and polar cooling in the Miocene: The Monterey hypothesis. The Carbon Cycle and Atmospheric CO: Natural Variations Archean to Present, 455-468.

Usui, Y., Yamazaki, T., and Saitoh, M., 2017. Changing abundance of magnetofossil morphologies in pelagic red clay around Minamitorishima, Western North Pacific. Geochem. Geophys. Geosyst., 18, 4558-4572.

Voegelin, A., Kaegi, R., Frommer, J., Vantelon, D., Hug, S.J. (2010). Effect of phosphate, silicate, and $\mathrm{Ca}$ on $\mathrm{Fe}(\mathrm{III})$-precipitates formed in aerated $\mathrm{Fe}(\mathrm{II})$ - and $\mathrm{As}(\mathrm{III})$-containing water studied by X-ray absorption spectroscopy. Geochim. Cosmochim. Acta, 74, 164-186. 
Yamazaki, T., Kawahata, H., (1998). Organic carbon flux controls the morphology of magnetofossils in sediments. Geology 26, 1064-1066. http://dx.doi.org/10.1130/ 00917613(1998)026b1064:OCFCTMN2.3.CO;2.

Yamazaki, T.(2008). Magnetostatic interactions in deep-sea sediments inferred from first order reversal curve diagrams: implications for relative paleointensity normalization. Geochem. Geophys. Geosyst. 9, Q02005. http://dx.doi.org/10.1029/2007GC001797.

Yamazaki, T. (2012). Paleoposition of the Intertropical Convergence Zone in the eastern Pacific inferred from glacial-interglacial changes in terrigenous and biogenic magnetic mineral fractions. Geology, 40(2), 151-154.

Yamazaki, T., Ikehara, M. (2012). Origin of magnetic mineral concentration variation in the Southern Ocean. Paleoceanography, 27, PA22306, doi:10.1029/2011PA002271.

Yamazaki, T., Shimono, T. (2013). Abundant bacterial magnetite occurrence in oxic red clay. Geology, 41, 1191-1194.

You, Y., Huber, M., Müller, R. D., Poulsen, C. J., \& Ribbe, J. (2009). Simulation of the middle Miocene climate optimum. Geophysical Research Letters, 36(4).

Wade, B.S., Pearson, P.N., Berggren, W.A., and Pälike, H., 2011, Review and revision of Cenozoic tropical planktonic foraminiferal biostratigraphy and calibration to the geomagnetic polarity and astronomical time scale: Earth-Science Reviews, v. 1

Walden, J.F., Oldfield, J., Smith, J. (1999). Environmental magnetism: a Practical Guide, No.6. Quaternary Research Association, Longon, 243pp.

Warny, S., Askin, R. A., Hannah, M. J., Mohr, B. A., Raine, J. I., Harwood, D. M., ... \& SMS Science Team. (2009). Palynomorphs from a sediment core reveal a sudden remarkably warm Antarctica during the middle Miocene. Geology, 37(10), 955-958.

Weast, R.C. 1969. Handbook of Chemistry and Physics. Cleveland CRC press.

Weeks, R., Laj, C., Endignoux, L., Fuller, M., Roberts, A., Manganne, R., Blanchard, E. and Goree, W., 1993. Improvements in long-core measurement techniques: Applications in 
palaeomagnetism and palaeoceanography. Geophysical Journal International, 114(3), pp.651662.

Westerhold, T., \& Röhl, U. (2013). Orbital pacing of Eocene climate during the Middle Eocene Climate Optimum and the chron $\mathrm{C} 19 \mathrm{r}$ event: Missing link found in the tropical western Atlantic. Geochemistry, Geophysics, Geosystems, 14(11), 4811-4825.

Wilson, D. S., Pollard, D., DeConto, R. M., Jamieson, S. S., \& Luyendyk, B. P. (2013). Initiation of the West Antarctic Ice Sheet and estimates of total Antarctic ice volume in the earliest Oligocene. Geophysical Research Letters, 40(16), 4305-4309.

Woodruff, F., \& Savin, S. M. (1989). Miocene deepwater oceanography. Paleoceanography, $4(1), 87-140$.

Yan, L., Zhang, S., Chen, P., Liu, H., Yin, H., Li, Hongyu. (2012) Magnetotactic bacteria, magnetosomes and their application. Microbiological Research. 169 (9), 507-519.

Xuan, C., and J. E. T. Channell (2009), UPmag: MATLAB software for viewing and processing u channel or other pass-through paleomagnetic data, Geochem. Geophys. Geosyst., 10, Q10Y07, doi:10.1029/2009GC002584.

Zachos, J.C., Quinn, T.M., Salamy, K.A., 1996. High resolution (104years) deep-sea foraminiferal stable isotope records of the Eocene-Oligocene climate transition. Paleoceanography 11, 251-266.

Zachos, J. C., Pagani, M., Sloan, L., Thomas, E., Billups, K. (2001). Trends, rhythms, and aberrations in global climate 65Ma to present. Science, 451, 279-283.

Zachos, J.; Dickens, G.; Zeebe, R. (2008). An early Cenozoic perspective on greenhouse warming and carbon-cycle dynamics. Nature. 451, 279-283, 2008. doi: 10.1038/nature06588

Zhang, C., Liu, S.V., Logan, J., Mazumder, R. and Phelps, T.J. (1996) Enhancement of Fe(III), $\mathrm{Co}(\mathrm{III})$, and $\mathrm{Cr}(\mathrm{VI})$ reduction at elevated temperatures and by a thermophilic bacterium. Applied Biochemistry and Biotechnology, 57/58, 923-932.

Zjiderveld, J.D.A., 1967, A.C. demagnetization of rocks, in Collison, D.W., Creer, K.M., and Runcorn, S.K., eds., Methods in Paleomagnetism: Amsterdam, Netherlands, Elsevier, p. 256286. 